\title{
Simulated and standardized patients in health profession education
}

Citation for published version (APA):

Schlegel, C. A. B. (2016). Simulated and standardized patients in health profession education: the impact of quality improvement. [Doctoral Thesis, Maastricht University]. https://doi.org/10.26481/dis.20160608cs

Document status and date:

Published: 01/01/2016

DOI:

$10.26481 /$ dis.20160608cs

Document Version:

Publisher's PDF, also known as Version of record

\section{Please check the document version of this publication:}

- A submitted manuscript is the version of the article upon submission and before peer-review. There can be important differences between the submitted version and the official published version of record.

People interested in the research are advised to contact the author for the final version of the publication, or visit the DOI to the publisher's website.

- The final author version and the galley proof are versions of the publication after peer review.

- The final published version features the final layout of the paper including the volume, issue and page numbers.

Link to publication

\footnotetext{
General rights rights.

- You may freely distribute the URL identifying the publication in the public portal. please follow below link for the End User Agreement:

www.umlib.nl/taverne-license

Take down policy

If you believe that this document breaches copyright please contact us at:

repository@maastrichtuniversity.nl

providing details and we will investigate your claim.
}

Copyright and moral rights for the publications made accessible in the public portal are retained by the authors and/or other copyright owners and it is a condition of accessing publications that users recognise and abide by the legal requirements associated with these

- Users may download and print one copy of any publication from the public portal for the purpose of private study or research.

- You may not further distribute the material or use it for any profit-making activity or commercial gain

If the publication is distributed under the terms of Article $25 \mathrm{fa}$ of the Dutch Copyright Act, indicated by the "Taverne" license above, 


\section{Claudia Schlegel}

\section{Simulated and standardized patients in health profession education:}

\section{The impact of quality improvement}

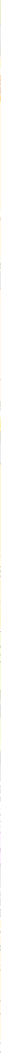


The research reported here was carried out at Dastricht University in Leamuing!

in the School of Health Professions Education
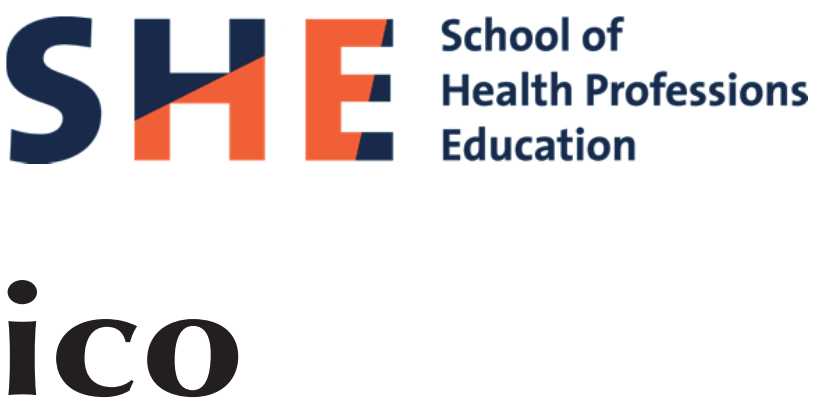

Interuniversity Centre for Educational Research 


\title{
Simulated and standardized patients in health profession education:
}

\author{
The impact of quality improvement
}

\author{
DISSERTATION \\ to obtain the degree of Doctor at Maastricht University, \\ on the authority of the Rector Magnificus, Prof. Dr. L.L.G. Soete \\ in accordance with the decision of the Board of Deans, \\ to be defended in public \\ on Wednesday 08 June 2016, at 14.00 hours
}

by

Claudia Schlegel 


\section{Supervisors}

Prof. Dr. Jan-Joost Rethans

Prof. Dr. Cees.P.M. van der Vleuten

\section{Co-supervisor}

Dr. Raphael Bonvin

\section{Assessment Committee}

Prof. Dr. Mirjam oude Egbrink (Chair)

Dr. Hay Derkx

Prof. Dr. Sylvia Heeneman

Prof. Dr. Nu Viet Vu

Dr. Evelyn van Weel-Baumgarten 
"When you get into a tight place and everything goes against you, till it seems as though you could not hang on a minute longer, never give up then, for that is just the place and time that the tide will turn."

Harriet Beecher-Stowe 1811-1896 



\section{Contents}

CHAPTER 1 Introduction

CHAPTER 2 The use of video in Standardized Patient training to improve portrayal accuracy: A randomized post-test control group study

Medical Teacher 2015; 37(8): 730-737

CHAPTER 3 Validity evidence and reliability of a simulated patient feedback instrument

BMC Medical Education 2012; 12(6): e1-5

CHAPTER 4 The impact of communication training on real practice performance:

A comparison of the effectiveness of a role-play module vs. a standardized-patient module in nursing education Journal of Nursing Education 2012; 51(1): 16-22

CHAPTER 5 Standardized patients' perspectives on workplace-satisfaction and work-related relationships: A multi-centre study Accepted for publication in Simulation in Health Care

CHAPTER 6 General Discussion

Summary

Samenvatting

Valorization

Acknowledgments

About the author

List of Publications

SHE dissertations series 

CHAPTER 1

Introduction 

An efficient healthcare system that aims to deliver safe and highly qualified patient care by all its healthcare professionals requires these professionals to acquire skills in key competences around the different health care 'roles' they have, as e.g. the role as medical expert, as communicator, and as collaborator (1).

Acquiring skills, i.e. the abilities and capacities acquired through deliberate, systematic and sustained effort to smoothly and adaptively carry out complex tasks and activities - involving cognitive, technical and interpersonal skills (2) - are becoming more and more a key competency within medical education. Modern education typically moves beyond the knowledge domain, preparing learners better to make the transfer to complex professional practice. This is done by giving learners authentic tasks in which they can train the transfer to practice. Virtual tasks are important, and therefore simulation is important. Simulation is a technique used to replace or amplify real experiences with guided experiences that evokes or replicates substantial aspects of the real world in a fully interactive fashion (3) and facilitates the learning process through immersion, reflection and feedback. There are several reasons why simulation in general is getting more attention, e.g. more emphasis on patient safety (4), new medical technology, shorter patient stays in hospitals and changing staff/student ratios. Simulations allow educational work to be practiced in a protected environment, which puts the learners in simulated, almost real-life situations without risks and consequences $(4,5)$. Consequently, this type of learning provides excellent opportunities to practice daily situations in an environment designed to look like and feel like the real situation (5).

Simulation is taken from the Latin simulare, 'to copy, represent' and is used as a method that enables the learning and training of individuals and teams by recreating 'real' situations (6). Simulation allows individuals or teams to learn, practice and repeat procedures as often as necessary in order to correct mistakes, develop professional competencies, or to experience whether one has sufficient knowledge and skills. Simulations also enable healthcare learners to act in a wide variety of situations (2), finetune skills and ultimately improve patient outcomes (5). In addition, tasks can also be staged according to experience level, allowing novices to practice core skills before attempting complex procedures (6). Healthcare simulation can be realized in many ways. There are different modalities of simulation (7), such as simulation technology that replicates the whole body or parts of bodies (simulators), simulation of/as real human beings and combinations of these. Simulation of/as real human beings, also referred to as standardized patients or simulated patients (SPS), are healthy persons trained to act as a real patient to simulate a set of symptoms or problems of a patient used in healthcare education (7). The word 'Standardized' patient is used here, because it is the standardization of a particular patient problem that gives this technique an advantage over the use of actual patients in teaching and assessment (8). The level of standardization varies according to the context in which the SP is used. In many learning settings, standardizations are less critical, and the word 'simulated' patient 
instead of standardized is more appropriate, thus placing more emphasis on the authenticy of the simulation instead of the standardization. Simulated patients playing the same patient role thus may, to a certain extent, vary in their presentation (as real human beings do), whereas this is not the case with standardized patients. (4).

Human simulations, also called human patient simulators, on the other hand, are high or low fidelity manikins (11-13), which replicate whole body appearance and variable physiological parameters (13).

Of course there are limitations to SPs and simulation technology. SPs are usually healthy people without the real abnormal physical findings of the patients they might need to portray (as they simulate) thus limiting their 'realness'. Simulators, while realistic in many ways, cannot e.g. produce the same stressors to learners as are experienced when health professionals perform the same procedures on real patients. For example simulators do not 'talk' to the learners. Kneebone and colleagues combined SPs and simulators: hybrid simulation (9). Hybrid simulation thus combines the realism of a live patient with physical components, represented by a model or simulator, that SPs do not have or that are difficult to use an SP for, such as insertion of a catheter or intravenous injections. Combining real human beings (SPs) with simulation technology = hybrid simulation, provides a safe and effective learning opportunity at absolutely no risk to SPs (10).

\section{Simulated and Standardized Patients}

In the early sixties Barrows described the need for a new patient-oriented method to test medical students in the domain of clinical skills, and named this method 'the programmed patient' (14). The reason for this need was that use of real patients in student examinations always introduced variation into the assessment, as patients inevitably vary, making students' competences difficult to compare. The 'programmed patient' was devised in an attempt to provide a more standardized test for students. The concept of the 'programmed patient' firstly involved the standardized simulation of only a neurological disease by a healthy person who had been trained to act out and present the history and behavior of an actual patient. Following this first attempt, the method was renamed 'the simulated method', as the idea of simulated patients (SPS) emphasizes the authenticity of the simulation. Its use was no longer restricted to neurological, but also encompassed other diseases (15-17). In the early 1970s, feedback given by simulated patients after a student encounter became important (15). In the 1980s, the use of SPs in assessment became common, e.g. in the Objective Structured Clinical Examination (OSCE) for medical students.

The ASPE (Association of Simulated and Standardized Patient Educators) defines an SP as: an individual who is trained to portray a simulated role in a realistic, and sometimes standardized and repeatable manner (where portrayal/presentation varies, based only on learner performance), used for education, assessment, program evalua- 
tion and research. Roles include: family members, healthcare professionals, faculty and students.

SPs' contribution is growing in medical, nursing and other health professions. They provide a unique and optimal environment in which to learn because it is risk-free and controllable. Students have the ability to explore techniques without causing harm. Schools can stage the difficulty of a particular task according to the students' level of competence.

\section{The quality of SP role training}

SPs can be used as simulated patients to support the learning of students (4) and/or as standardized patients for assessment purposes. This can be done unannounced (meaning that the learner/healthcare provider is not aware that the patient (s)he is faced with is not a real patient) or 'announced', where its is clear that 'it is all simulated'(19). At many medical schools SPs are used in Objective Structured Clinical Examinations (OSCE) (20). OSCEs consist of multiple standardized task-based stations that mainly evaluate clinical and communication skills. An important issue for an OSCE is that the same conditions are applied throughout, in order to compare student performance in high stakes exams. SPs are trained to give an accurate and consistent presentation of the patient case that does not vary from student to student (18). Standardization in this area is not only a matter of training an SP to accurately give the facts at the appropriate time during the encounter, but also of the standardization of behavior displayed (21). Standardization requires training the SPs to perform specific behaviors' when simulating physical states. All clinical, social, emotional and psychological aspects should be the same for each student and station (22). In other words, role accuracy is a key element in the training and use of SPs in examinations $(8,18,23,24)$. The quality of SP role training is key. The concepts of SP role training in general are well described in the literature $(18,21,22)$. However the efficacy of various training methods used to enable SPs to reproduce a standardized role script accurately needs further investigation. There is definitely a need for research as to which training methods are best to 'produce' well trained SPs. Determining which training methods lead to qualitatively better accuracy of SP performance and what impact training with video can have during SP role-training are key areas for further scientific inquiry.

\section{SPs and feedback on interpersonal skills}

As the patient is becoming more and more the focal point of medical teaching and learning (10), interpersonal skills (skills used every day to communicate and interact with other people) (25) have become important. There is a heightened interest in including patient perspectives at all stages of medical and health professional curriculum design. To capture a patient perspective, human simulators are less than ideal because 
of their inability to give feedback from a patient's perspective. Thus, besides employing SPs for assessment, medical education programs also use them to support student learning of interpersonal communication. This can be carried out in complete simulated patient-'doctor' consultations in which learners can practice their skills in taking a medical history, performing physical examination and discussing a management plan with the SP. In these settings SPs are trained to give feedback on a consultation from the patient's perspective.(18).

When SPs give high quality feedback, this helps students to develop their interpersonal skills $(26,27)$. As mentioned earlier, there is an increasing awareness of the need to train tomorrow's health professionals in interpersonal skills. Effective interpersonal skills between patient and health professionals are basic clinical skill that demands teaching just as much as, e.g., physical examination (28). It is assumed that when health professionals have effective communication skills, patients are more likely to comply with medical treatment and therefore ought to have a better outcome (29). Health professionals should therefore work towards patient-centered communication through shared decision-making and effective interaction with patients, families, other professionals, and other important individuals (1). This is essential for establishing rapport and trust, delivering information, striving for mutual understanding, and facilitating a shared plan of care. Poor communication can lead to undesired patient outcomes (1). There is ample evidence that high quality communication skill training improves healthcare professionals' communicative competence $(30,31)$. It is assumed that employing SPs to train students in interpersonal skills has an impact on their clinical practice. High quality SP performance and feedback therefore fosters student learning.

\section{The quality of Simulated Patient feedback to students}

The provision of feedback to students is thus an integral part of teaching with simulated patients (32). The ability of SPs to give immediate and specific oral feedback on an encounter with a student is one of the advantages of using SPs (32). Feedback can be understood as specific information based on the comparison between a student's observed performance and a standard, given with the intent to improve the student's performance as a healthcare professional (33). SPs can be trained to assess the students' performance and provide oral feedback to the students (18). High-quality feedback can have a profound effect on student performance (34) and is, therefore, vital to the overall effectiveness of training. The quality of the SP feedback to the student, on the other hand, must be monitored and evaluated by the SP trainer (35). Feedback to SPs from the trainer is not only about error correction, but also has motivational effects, which enables SPs to develop intrinsic motivation and interest and also supports feelings of competence (36). Consequently, instruments to evaluate the quality of SP feedback are needed. 
During the last fifty years of employing SPs in medical and health professional education, the requirements for performing as SPs have increased steadily and thus the work of SPs has become more demanding and sometimes more difficult. As mentioned before, SPs are professional actors, or lay people employed by an institution full-time, part-time or by the hour. Motivations for people wanting to become an SP vary. Among these are altruistic reasons, interest in contributing to the development of medical education or just earning money (37). As SPs are now essential to healthcare training, yet face challenging demands in their work, it is important to know whether SPs feel supported by the SP trainer and are satisfied with their workplace. Workplace satisfaction describes people's assessment of their job in terms of the issues and concerns that matter; the feelings and emotions involved in work will have a considerable influence on the person's work attitude (38). Positive work satisfaction leads to positive work engagement, because those engaged are intrinsically motivated, prepared to face new challenges, show pro-social behavior, process gathered facts better and are recognized by their high quality performance (39). It is essential for SP programs, coordinators and trainers to explore the issue of SPs' well-being in greater depth, if they want to keep the SPs they have so carefully trained.

Over more than half a century SPs have offered a unique contribution to health profession education. Since SPs appeared upon the scene, a great diversity of approaches have been explored, described and published (4). As the SP community and its programs grow worldwide, new insights into training and evaluation are necessary to match new demands of education and society. Clearly, there is a continuous need to adapt SP programs to these new demands. In a world where efficiency is important, purposeful and continuous quality improvement of SP performance and its evaluation is essential to keep this method powerful for learning and assessment. Therefore a high quality SP program affects all stakeholders: students, patients, SPs themselves, SP trainers, clinical supervisors and many more. Despite this, little research has been published about the effect that the SP method has on its stakeholders.

Based on the above-mentioned need for evidence on training methods for good SP role play, the effect of SPs on stakeholders and SPs' well-being, the following research questions guided all investigations presented here:

Research question 1: What elements improve the quality SP performance when it comes to training methods and feedback?

Research question 2: How does the quality of the SP methodology affect its stakeholders?

To answer these two research questions we conducted four empirical studies, which comprise chapters 2 through 5 . The first research question emphasizing quality improvement is answered in Chapters 2 and 3 . The second research question focused on the impact of improved quality on its stakeholders is answered in Chapters 4 and 5. 
Chapter 2 focuses on the quality of SP role-training for Objective Structured Clinical Examinations (OSCE). An important issue for an OSCE is that the same conditions apply throughout the exam, in order to compare student performance in high stakes exams. SP performance should therefore be as accurate and close to the standardized script as possible. In this study the impact of video in SP training is examined in terms of the SPs' role accuracy. The effect of different types of SP video training on the accuracy of SP portrayal is investigated.

Chapter $\mathbf{3}$ focuses on the quality of SP oral feedback to students after a simulated clinical encounter. The quality of SP feedback must be monitored, especially because it is well known that feedback can have a profound effect on student performance. Feedback enables individuals to develop intrinsic motivation and interest and is assumed to support feelings of competence. In addition, further attributes of feedback are concentrated around error correction and achievement change and can have motivational effects (36). It is therefore recommended for SP development that SP performance feedback should be institutionalized in SP programs to increase quality and the opportunity to learn and to develop. The goal of this study was to validate an SP feedback instrument to measure the quality of SPs' oral feedback.

Chapter $\mathbf{4}$ focuses on the effectiveness of teaching modules involving SPs on its stakeholders. It investigates the question of whether students who have had an SP encounter in a skills lab perform better in real clinical practice with real patients. The study investigates the extent to which SP role- and feedback training has an impact on students' performance in real practice with real patients. This is discussed in terms of patients' perceptions as well as those of their clinical supervisors, and also in terms of students' feelings of preparedness after SP encounters when facing real patients.

Chapter $\mathbf{5}$ focuses on SPs' perspectives on workplace-satisfaction and work-related relationships. It is a qualitative study where SPs from several institutions have been interviewed. The reason for this study is the changing role of SPs with more demanding tasks. While the original emphasis of use of SPs was on portraying a patient only, the quality of SPs' feedback after a student encounter also became important: students were given feedback on their interviewing skills. In the 1980s, the use of SPs in assessment became common, e.g. in the Objective Structured Clinical Examination (OSCE), It is important to know and understand the SP perspectives, so that SPs get enough support for their increasing requirements and therefore devote effort to achieving the SP program's objectives and remain with the organization.

Since this dissertation consists of separate papers for the international literature, some repetition of information across chapters cannot be avoided. 


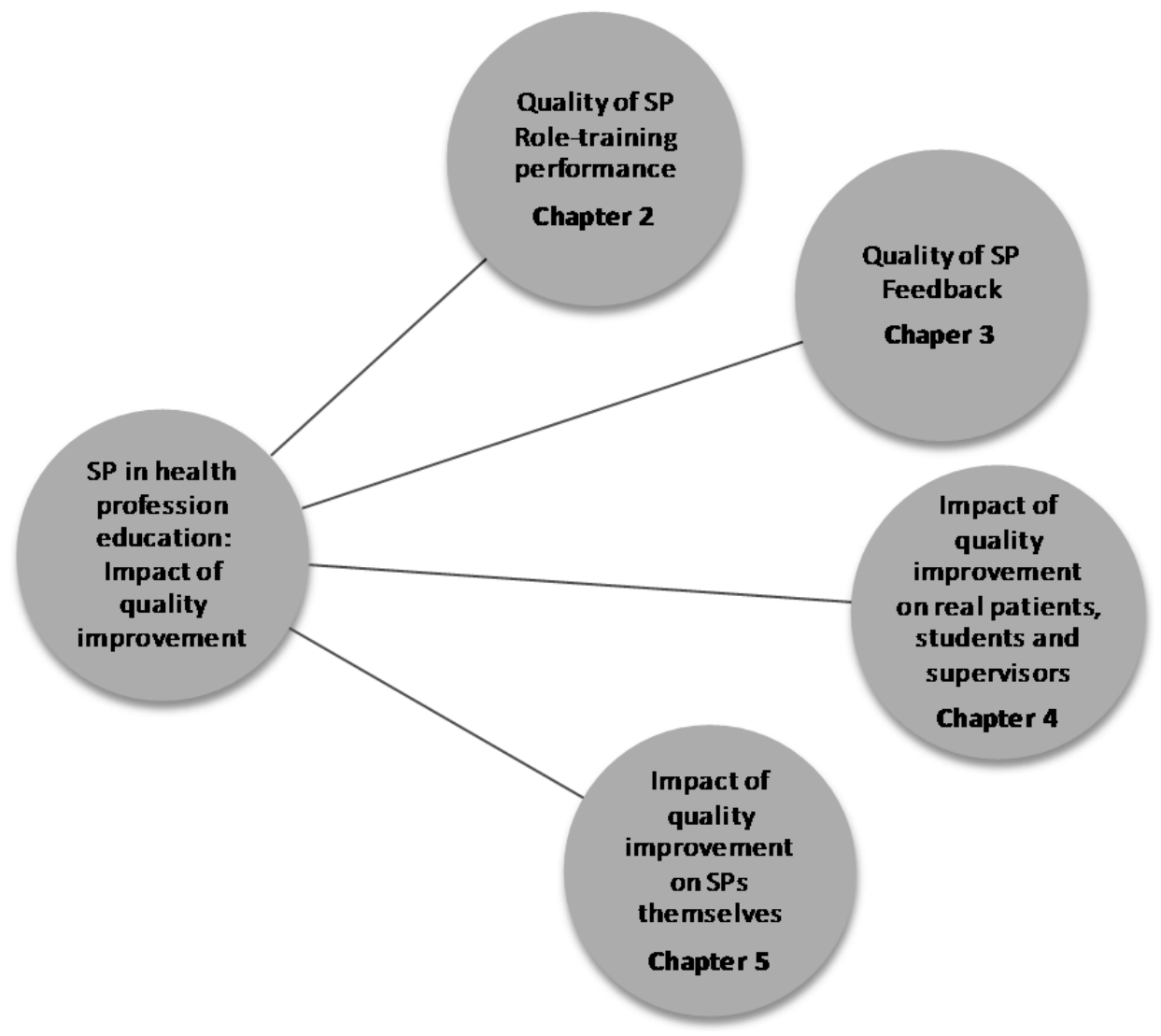

Figure 1: Outline of thesis 


\section{LITERATURE}

1. Frank JR, Danoff D. The CanMEDS initiative: implementing an outcomes-based framework of physician competencies. Medical Teacher. 2007 Sep;29(7):642-7.

2. Luthra V. Business Dictionary.com. Fairfax2007; Available from: http://www.businessdictionary.com/ definition/skill.html - ixzz3VKRYEmtS.

3. Gaba D. The future vision of simulation in healthcare. Quality \& Safety in Healthcare. 2007;13:i2-i10.

4. Nestel D, Bearman M, editors. Simulated Patient Methodology. Oxford: Wiley Blackwell; 2015.

5. Schlegel C, Shaha M. Turning old into new. Clin Teach. 2014 Dec;11(7):561-2.

6. Datta R, Upadhyay K, Jaideep C. Simulation and its role in medical education. Medical Journal Armed Forces India. 2012;68(2):167-72.

7. Palaganas J, C.,, Maxworthy J, C.,, Epps C, A.,, Mancini ME, editors. Defining Excellence in Simulation Programs. First Edition ed. Philadelphia: Society for Simuation in Healthcare; 2015.

8. Norman GR, Tugwell P, Feightner JW. A comparison of resident performance on real and simulated patients. Journal of Medical Education. 1982/09/01 ed1982. p. 708-15.

9. Kneebone R. Evaluating clinical simulations for learning procedural skills: a theory-based approach. Acad Med. [Review]. 2005 Jun;80(6):549-53.

10. Nestel D, Kneebone R. Perspective: authentic patient perspectives in simulations for procedural and surgical skills. Acad Med. 2010 May;85(5):889-93.

11. Marken PA, Zimmerman C, Kennedy C, Schremmer R, Smith KV. Human simulators and standardized patients to teach difficult conversations to interprofessional health care teams. Am J Pharm Educ. 2010 Sep 10;74(7):120.

12. Chang CS. Moderating effects of nurses'organizational support on the relationship between job satisfaction and organizational commitment. Western Journal of Nursing Research. 2014(April).

13. Bradley P. The history of simulation in medical education and possible future directions. Medical Education. [Historical Article]. 2006 Mar;40(3):254-62.

14. Barrows HS, Abrahamson S. The Programmed Patient: A Technique for Appraising Student Performance in Clinical Neurology. Journal of Medical Education. 1964 Aug;39:802-5.

15. Stillman PL, Brown R, Redfield DL, Sabers DL. Construct validation of the arizona clinical interview rating scale. Educational and psychological Measurement. 1977;37:1031-8.

16. Barrows HS. Simulated patients in medical teaching. Can Med Assoc J. 1968 Apr 6;98(14):674-6.

17. Adamo G. Simulated and standardized patients in OSCEs: achievements and challenges 1992-2003. Medical Teacher. 2003 May;25(3):262-70.

18. Cleland J, Abe K, Rethans J. The Use of Simulated Patients in Medical Education. In: Education AGiM, editor. Dundee: AMEE Guide; 2010.

19. Rethans JJ, Gorter S, Bokken L, Morrison L. Unannounced standardised patients in real practice: a systematic literature review. Medical Education. [Review]. 2007 Jun;41(6):537-49.

20. Harden R, Stevenson M, Downie WW, Wilson GM. Assessment of clinical Competence using Objective Structured Clinical Examination. British Medical Journal. 1975;1(February):447-51.

21. Wallace P. Coaching standardized patients for use in assessment of clinical competence. New York: Springer Publishing Company; 2007.

22. Dudley F. The Simulated Patient Handbook. London, New York: Radcliffe Publishing; 2012.

23. Hatala R, Marr S, Cuncic C, Bacchus CM. Modification of an OSCE format to enhance patient continuity in a high-stakes assessment of clinical performance. BMC Medical Education. [Research Support, NonU.S. Gov't]. 2011;11:23.

24. Boulet JR, De Champlain AF, McKinley DW. Setting defensible performance standards on OSCEs and standardized patient examinations. Medical Teacher. 2003 May;25(3):245-9.

25. SkillsYouNeed. What is Communication? Wales2014; Available from: http://www.skillsyouneed.com/ general/what-is-communication.html. 
26. Schlegel C, Shaha M. Pilotprojekt: Praxisnahes Unterrichten in der Pflegeausbildung mit Standardisierten Patienten- ein Gewinn für alle! Printernet. 2007(03):169-71.

27. Wang S, Shadrake L, Lyon MJ, Kim H, Yudkowsky R, Hernandez C. Standardized patient-based assessment of dermatology resident communication and interpersonal skills. JAMA Dermatol. [Research Support, N.I.H., Extramural Research Support, Non-U.S. Gov't]. 2015 Mar;151(3):340-2.

28. Kurtz S, Silverman J, Draper J, editors. Teaching and learning communication skills in medicine. 2nd ed: Radcliff Medical Press; 2005.

29. Guldvog B. Can patient satisfaction improve health among patients with angina pectoris? . Int J Qual Health Care. 1999;11:233-40.

30. Stewart M, Weston JB, Mc Whinney IR, McWilliam CL, Freeman TR, editors. Patient-centered medicine: transforming the clinical method.: Sage; 1995.

31. Smith RC, Lyles JS, Mettler JA, NMarshall AA, Van Green LF, Stoffelmayr BE, et al. A strategy for improving patient satisfaction by the intensive training of residents in psychososcial medicine: a controlled, randomized study. Academic Medicine. 1995;70(8):729-32.

32. Bokken L, Linssen T, Scherpbier A, van der Vleuten CPM, Rethans J. Feedack by simulated patients in undergraduate medical education: a systemic review of the literature. Medical Education. 2009;43(11):202-10.

33. van de Ridder JMM, Stokking KM, McGaghie W, ten Cate OTJ. What is feedback in clinical education? Medical Education. 2008;42:189-97.

34. Shute VJ. Focus on formative feedback. Review of Educational Research. 2008;78(1):153-89.

35. Schlegel C, Woermann U, Rethans JJ, van der Vleuten C. Validity evidence and reliability of a simulated patient feedback instrument. BMC Medical Education. 2012;12:6.

36. Harks B, Rakoczy K, Hattie J, Besser M, Klieme E. The effects of feedback on achievement, interest and self-evaluation: the role of feedback's perceived usefulness. Educational Psychology. 2014;34(3):269-90.

37. Nestel D, Tabak D, Tierney T, Layat-Burn C, Robb A, Clark S, et al. Key challenges in simulated patient programs: an international comparative case study. BMC Medical Education. [Comparative Study]. 2011;11:69.

38. Sempane M, Rieger $H$, Roodt $G$. Job satisfaction in relation to organizational culture. Journal of Industrial Psychologie. 2002;28(2):23-30.

39. Schaufeli WB, Bakker AB, Van Rehenen W. How changes in Job demands and resources predict burnout, work engegement, and sickness absenteeinsm. Journal of Organizational Behaviour. 2009; 30(7):893-917. 



\section{CHAPTER 2}

The use of video in Standardized Patient training to improve portrayal accuracy: A randomized post-test control group study

Schlegel Claudia

Bonvin Raphael

Rethans Jan-Joost

Van der Vleuten Cees P.M.

Medical Teacher 2015; Vol 37, Issue 8, p 730-737 


\section{ABSTRACT}

\section{Introduction}

High-stake Objective Structured Clinical Examinations (OSCEs) with standardized patients (SPs) should offer the same conditions to all candidates throughout the exam. SP performance should therefore be as accurate and close to the original role script as possible during all encounters. For this reason role accuracy is a key element in the training and use of SPs in examinations. In this study we examined the impact of video in SP training on SPs' role accuracy, investigating how the use of different types of video during SP training improves the accuracy of SP portrayal.

\section{Methods}

In a randomized post-test control group design three intervention groups of 12 SPS each with different types of video training and one control group of 12 SPs without video use in SP training were compared. The three intervention groups used rolemodeling video, performance-feedback video or a combination of both. The same experienced SP trainer trained each group for the same case in a 90-minute session. Each SP performed four sequential portrayals with students. Two blinded faculty members rated the 192 video-recorded encounters, using a case-specific rating instrument to assess SPs' role accuracy.

\section{Results}

SPs trained by video showed significantly $(p<.001)$ better role accuracy than SPs trained without video over the four sequential portrayals. There was no difference between the three types of video training.

\section{Discussion}

Use of video during SP training enhances the accuracy of SP portrayal compared with no video, regardless of the type of video intervention used. 


\section{INTRODUCTION}

Standardized patients (SPs) are professional or non-professional actors trained to present a reproducible and unbiased presentation of an actual patient case (1, 2). SPs can be trained to consistently reproduce the history, emotional tone, communicative style and physical signs of an actual patient and are therefore preferred over real patients in teaching and assessment (3-6). As a result, SP methodology, both for educational and evaluative purposes, has evolved considerably over the past few decades $(5,7,8)$.

In schools for the training of health care professionals, clinical skills are frequently observed and assessed by means of, e.g., the Objective Structured Clinical Exam (OSCE) $(5,7-10)$, preferably with standardized patients, because they ensure consistent clinical scenarios with high degrees of reproducibility and thus help to reduce some of the variability between students' experiences $(7,11)$. In order to compare student performance in high stakes exams, it is important that the same conditions are applied throughout. SP performance should therefore be as accurate and close to the standardized script as possible. SPs should play their roles exactly as trained by the SP trainer; all clinical, social, emotional and psychological aspects should be the same for each student and station (12). In other words, role accuracy is a key element in the training and use of SPs in examinations $(4,8,10,11)$.

However, the question of what training methods provide sustainable results with regard to accuracy remains unanswered. Very few studies have been published (13) on the use of videos in SP training, either as role modeling videos or performancefeedback videos, even though it has been suggested that they may optimize training time, improve SP performance, and enhance script recall performance (14).

In general, the literature shows that video, as an additional tool in training, has a positive impact on performance. Shippey et al. (15) investigated improvement of skills in subcuticular suturing using a modeling video with medical students, suggesting it was indeed effective. Gupta \& Sehgal (16) compared patient training by physiotherapists using a modeling video and feedback on patient performance with the use of written instructions. Their study showed that patients who used videos performed more accurately than the others. In a pilot study, Hu et al. (17) described a performance video intervention with individualized oral feedback on intraoperative performance. They concluded that video-based coaching is a modality that targets judgments, technique and learning. With regard to video performance feedback Scherer et al. (18) investigated the review of performance videotape as a strategy for improving future performance in trauma resuscitations. They showed that participants' behavior improves with performance feedback video. They also mention that performance feedback videos can be an important learning tool because they foster self-directed learning. Moreover, according to Parsons \& Alexander (19), even a single session of video and verbal feedback on a performance was shown to have a positive effect. 
However, our literature search on the use of videos in SP role training and their effect on the accuracy of acting yielded few results. Although the use of modeling videos in SP training is described, the effects of such use on role accuracy are not reported. Several articles (20-23) report on video-taped models during SP training sessions for psychiatric cases. Wallace (24), used modeling-videos for new SPs and contends that modeling videos can foster rote and lifeless performance, that the best training experience is a more fluid interactive process than what is achieved by using a video recording as the means of standardization. In sum, the apparent lack of research on optimal training for SPs' accurate portrayal training clearly requires further investigation into the topic of SP portrayal training using video.

Because in the above-mentioned literature mainly two different types of videotraining in SP portrayal training the role-modeling video (RMV), and the performancefeedback video (PFV), were described, this study assesses both methods. The RMV presents the "original" patient role performed either by a real patient or an SP. In their training, the SPs watch the RMV of the case they have to portray. Thus, in the RMV training approach, by looking at a model, we encourage the SPs to imitate the model, reflect on it and question certain behaviours in more detail. The PFV, on the other hand, is a video recording of the SPs playing their role during training. The video is used as the basis for discussion and self-reflective analysis by SPs of their own performance to help improve their portrayal.

Since the literature considers RMV or PFV to be powerful teaching and learning tools, we compared three intervention groups 1) SPs trained with RMV, 2) SPs trained with PFV, 3) SPs trained with a combination of RMV \& PFV, with a control group of SPS trained without video. The use of video (RMV or PFV) requires extra resources (technical, financial and human) to enhance SP training. To justify these extra resources, there must be sufficient evidence of its added value. This leads us to the research question on the extent to which using video during SP portrayal training has an impact on the accuracy of SP portrayal, as measured by a case-specific rating instrument.

As we could envisage that a combination of the two video methods named would be an even better method for role accuracy training, we hypothesized that the combination of RMV and PFV in SP training would increase the degree of accuracy of SP performance compared to training with either RMV or PFV alone, or compared to training with no video at all.

\section{METHOD}

\section{Definition of performance accuracy}

SP role accuracy refers to how well an SP's performance matches the original SP role description. The gold standard for our study was defined as the $100 \%$ portrayal of all 
essential clinical elements including personality and affective features of the actual patient problem as described in the script.

\section{Subjects}

This study was conducted at the School of Nursing in Bern, Switzerland. A total of 48 novice SPs, all non-professional actors with no previous experience as an SP and or of OSCE exams were recruited from among staff volunteers. They all had at least a bachelor's degree in various fields and were between 23 and 65 years of age, which is similar to the age of SPs we usually employ. There were 23 female and 25 male SPs. The SPs were randomly assigned electronically to one of the four study groups, which ended up with a comparable balance of age and gender.

To avoid contamination we prevented SPs in the different groups from talking with each other about their training by asking them beforehand to sign a non-disclosure form.

\section{Patient Case}

To obtain meaningful results we chose a patient case with a challenging training format, for which we consulted the existing literature on SP training $(12,20,25,26)$. Criteria for developing the case were: the case portrayal should not be too short (about seven minutes), should have verbal, non-verbal and para-verbal (tone of voice, articulation, volume, rate of speech and intonation including pauses and silences) clues, should be 'challenging to deal with', difficult to portray and transferable to SP gender and SP age.

Based on these criteria, we decided on a case of a diabetes mellitus type I patient with early symptoms of hypoglycemia. A senior emergency ward doctor with experience in writing scripts developed the script for this case. The patient had injected his/her normal dose of insulin but during meal preparation had cut his/her right hand. The patient immediately went to emergency, forgetting to eat. The SP role-play begins when the patient is left alone in the emergency ward waiting for further treatment of his/her hand after initial treatment by a nurse. The patient is becoming confused, complaining about being hungry and having a headache. Moreover, s/he is irritated, aggressive, trembling and shaky. Because $\mathrm{s} / \mathrm{he}$ is worried about the situation $\mathrm{s} / \mathrm{he}$ rings the bell and a student-nurse $s /$ he has not met before enters the room.

To produce a template for the modeling-video, a professional actor acted the sequence of events under the supervision of the case author. The case was then piloted with an experienced SP and a faculty member. This resulted in modifying the script by improving more case-specific aspects so as to have a more challenging situation. 


\section{Design}

We used a randomized post-test control group design with three intervention groups of 12 SPs each and one control group of 12 SPs (48 SPs totally). In the role-modeling video group (RMV) SPs watched a role-model video and received oral feedback on their performance without video. In the performance-feedback video group (PFV) the SP role-play training was videotaped and SPs received oral feedback on their training performance, based on the relevant video recording. The third intervention group was the combination of RMV \& PFV, whereby SPs watched a role-modeling video and then were videotaped during role-play training, receiving oral feedback based on the video of their training performance. Finally, in the control group, training was done without video. Instead of a video the script was discussed and SPs received oral feedback on their training performance.

\section{Training}

The Stanislavsky acting method for portrayal training was used. (20). Stanislavsky required his students to feel what the characters might be feeling within a scene (27).

The same qualified SP trainer trained the four groups of 12 SPs from each intervention/control group. A second trainer was in the room as an observer to make sure that the SP trainer kept to the training format (Table 1). In none of the four groups did the second trainer make any corrections. The 12 SPs trained in pairs, one playing the role of the nursing student and one the patient. Training in pairs has advantages for SPs: they practice, and thus experience, both sides of a student - nurse encounter. Both the trainer and the SP colleague (who acts as the student-nurse) provide feedback on the SP portrayal performance. Seeing the other SP in role training helps both of them appreciate their own strengths and weaknesses. Under the guidance of the trainer and SP colleagues, SPs are able to reflect on and analyze their performance. They benefit from immediate oral feedback from the trainer and the SP colleague. The mutual feedback is structured, trainer-guided but SP-centered. With regard to the structure of the training, and to rehearse the anchor points of the script, SPs received training similar to Cleland et al. (11) training steps (Table 1). In addition, some participants felt inhibited by the presence of the camera. Therefore we followed the recommendation of Raymond et al. (28), to develop rules among the participants for respectful behavior while watching the video during SP training.

We could not find the optimal duration of time for SP portrayal training in the literature. Wallace (24), recommended limiting a single training session to no more than 3 $1 / 2$ hours. SPs become fatigued and their resulting inability to concentrate only leads to diminishing returns. Based on these considerations the standardized training was set to one single 90-minute session for all groups. 
Table 1: Training format of the different groups

The duration of the training for all groups was 90 minutes

\begin{tabular}{|c|c|c|c|c|}
\hline & $\begin{array}{l}\text { Group } 1 \\
\text { Role-modeling video } \\
\text { (RMV) }\end{array}$ & $\begin{array}{l}\text { Group } 2 \\
\text { Performance feedback } \\
\text { video (PFV) }\end{array}$ & $\begin{array}{l}\text { Group } 3 \\
\text { Combination of } \\
\text { RMV\&PFV }\end{array}$ & $\begin{array}{l}\text { Group } 4 \\
\text { Control Group }\end{array}$ \\
\hline & $12 \mathrm{SPs}$ & 12 SPs & 12 SPs & $12 \mathrm{SPs}$ \\
\hline $30^{\prime}$ & $\begin{array}{l}\text { 1. Understanding the } \\
\text { role / case including key } \\
\text { issues like facial } \\
\text { expression and wording, } \\
\text { incl. watching role- } \\
\text { modeling video with the } \\
\text { whole group }\end{array}$ & $\begin{array}{l}\text { 1. Understanding the } \\
\text { role / case including key } \\
\text { issues like facial } \\
\text { expression and wording } \\
\text { with the whole group }\end{array}$ & $\begin{array}{l}\text { 1. Understanding the role } \\
\text { / case including key } \\
\text { issues like facial } \\
\text { expression and wording, } \\
\text { incl. watching role- } \\
\text { modeling video with the } \\
\text { whole group }\end{array}$ & $\begin{array}{l}\text { 1. Understanding the } \\
\text { role / case including key } \\
\text { issues like facial } \\
\text { expression and wording }\end{array}$ \\
\hline $30^{\prime}$ & $\begin{array}{l}\text { 2. Performing the role / } \\
\text { case in groups of two. }\end{array}$ & $\begin{array}{l}\text { 2. Performing the role / } \\
\text { case in groups of two. } \\
\text { Performance is filmed. }\end{array}$ & $\begin{array}{l}\text { 2. Performing the role / } \\
\text { case in groups of two. } \\
\text { Performance is filmed. }\end{array}$ & $\begin{array}{l}\text { 2. Performing the role / } \\
\text { case in groups of two. }\end{array}$ \\
\hline $30^{\prime}$ & $\begin{array}{l}\text { 3. Self-reflection by the } \\
\text { SP who played the } \\
\text { patient, followed by } \\
\text { structured feedback on } \\
\text { performance from the } \\
\text { SP colleague and SP } \\
\text { trainer. }\end{array}$ & $\begin{array}{l}\text { 3. Self-reflection by the } \\
\text { SP who played the } \\
\text { patient, followed by } \\
\text { structured feedback on } \\
\text { performance from the SP } \\
\text { colleague and SP trainer } \\
\text { based on video. }\end{array}$ & $\begin{array}{l}\text { 3. Self-reflection by the } \\
\text { SP who played the } \\
\text { patient, followed by } \\
\text { structured feedback on } \\
\text { performance from the SP } \\
\text { colleague and SP trainer } \\
\text { based on video. }\end{array}$ & $\begin{array}{l}\text { 3. Self-reflection by the } \\
\text { SP who played the } \\
\text { patient, followed by } \\
\text { structured feedback on } \\
\text { performance from the } \\
\text { SP colleague and SP } \\
\text { trainer. }\end{array}$ \\
\hline
\end{tabular}

\section{Procedure}

The whole study took four days to stage, that is, one day per video intervention or control group. Each group had training in the morning and the student encounter with the trained case in the afternoon. For their performance SPs were randomized to a particular station. Four third-year nursing students, two female and two male, had a nurse-patient encounter with the 48 SPs (12 per day) from the four groups. The students were prepared for their task and asked to play their role as if the situation in each encounter was new for them.

To prevent any bias of premature closure $(29,30)$, the students were continuously observed and, when necessary, recalibrated after every few SP contacts. Otherwise the students were not specifically trained and were asked to play their part as naturally as possible. The students were blind as to the four study groups. The four students started simultaneously, student 1 at station one, student 2, at station two, and so on. Patient encounters lasted 7 minutes. After the encounter, students rotated to the next SP.

All encounters between SPs and students were video recorded. Two faculty members with a Master's degree in nursing science rated the 192 videos (48 SPs $x 4$ student encounters) in randomized order. These two expert nurses were given a briefing of the script, the case-specific rating scale and saw the role modeling film. To foster a common understanding of the items, the two expert nurses did a trial run with the case- 


\section{CHAPTER 2}

specific rating instrument, so that they had the same understanding of the items. The two raters were fluent in English, so the case-specific rating instrument was not translated into German. The raters were blind as to which SPs were in the RMV, PFV, RMV\&PFV or control group.

\section{Instrument}

The SP performance accuracy was measured on a case-specific rating instrument, which was developed for the case and reviewed by the senior emergency ward doctor who was consulted for developing the script. The items of the instrument were chosen to match the important portrayal elements of the script (see Table 2). The instrument was divided into two parts. The first part consisted of a 27-item dichotomous checklist, organized into four subscales: "verbal" (11 items), "non-verbal" (9 items), "para-verbal" (4 items), and "SP mentions only when asked" ( 3 items). The second part consisted of a four-item global rating (four point rating scale: 4=always, 1=rarely) to rate the accuracy of the SP performance. The instrument was piloted with an experienced SP and faculty members. This resulted in modifying the items to improve comprehensibility.

Table 2: Items of the Case Specific Rating Instrument Dichotomous checklist (done, not done)

\footnotetext{
Verbal SP communication:

1 Delivers correct opening line: "I am glad you came."

2 Complains that (s)he feels sick, two or more times during consultation (once or not at all equals "not done")

3 Complains that (s)he is hungry until student reacts

4 States that (s)he has not eaten for a while until student reacts

5 Asks if (s)he can get something to eat, until student reacts

6 If answer is no (to question 5), insists that he/she needs something to eat

7 Complains that (s)he feels nauseous, two or more times during consultation (once or not at all equals "not done")

8 Complains about a headache two or more times during consultation (once or not at all equals "not done")

9 Asks for the doctor two or more times during consultation (once or not at all equals "not done")

10 Worries that (s)he is trembling no more than two times during consultation. If SP mentions trembling three times it is "not done"

11 SP says that (s)he is reassured when student-nurse says she will measure blood sugar
} 


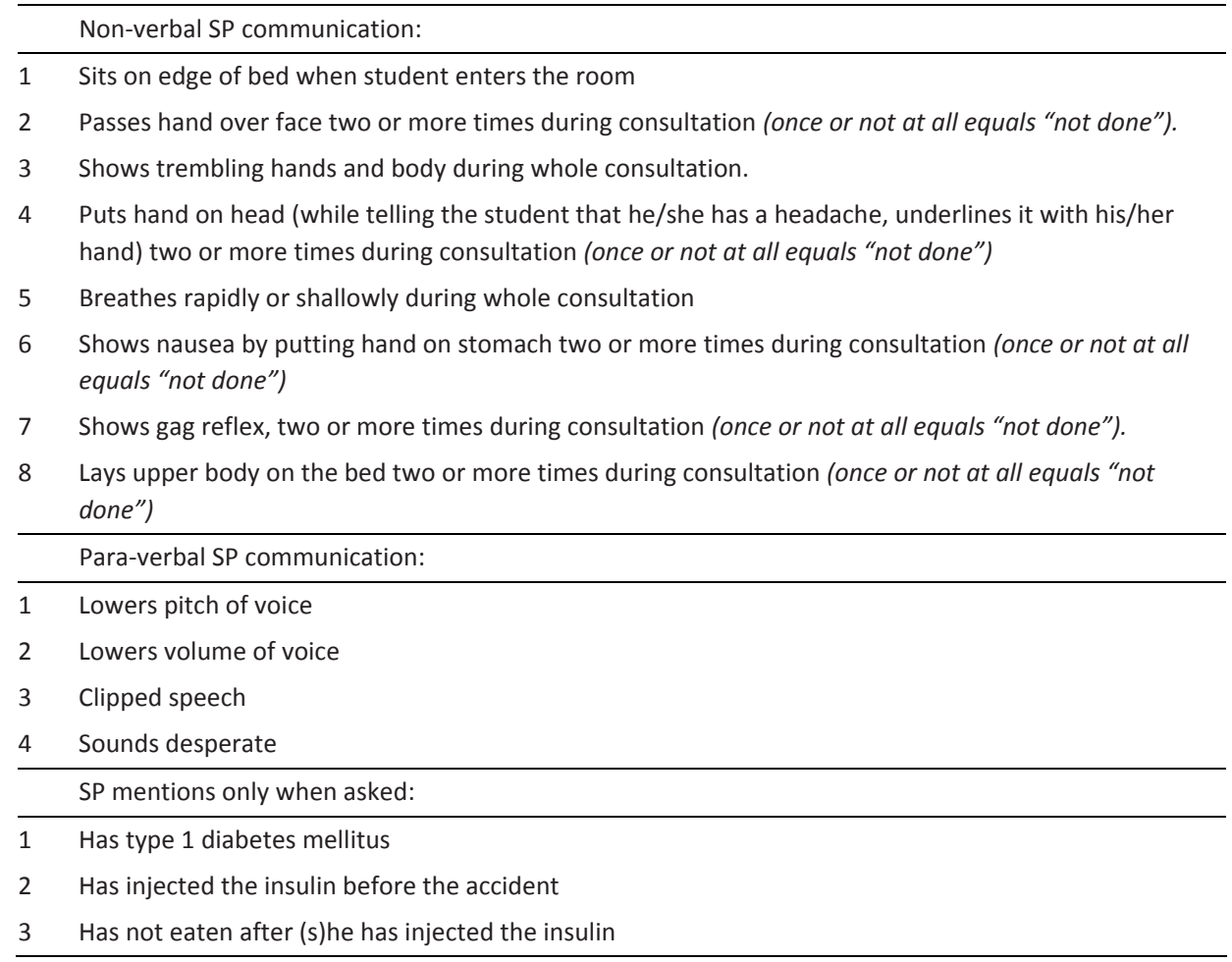

Global Rating (four-point rating scale 4=always, 1=rarely).

The SP:

1 Played the role well according to the standardized script

2 Maintained correct affect throughout encounter

3 The SP reacted naturally during the consultation

4 Stayed in the role very well during the consultation

\section{Ethical considerations}

Ethical approval was obtained from the ethics committee of the Canton of Bern, Switzerland. Informed consent was obtained from all participating students and SPs. Participation in the study was completely voluntary. All participants were free to leave the study at any time without any repercussions. The SPs and students received no financial compensation for their participation. 


\section{Analysis}

A sample size of 48 SPs (12 SPs per group) was calculated using G-Power (31) for $80 \%$ power to detect a $20 \%$ difference at a significance level of $\alpha=0.05$, based on a middle effect size of 0.5 (32).

The inter-rater reliability of the two raters over all the ratings of the case-specific rating instrument (dichotomous checklist and global rating) was expressed in a Pearson's $r$ correlation and was 0.63 .

The overall mean for role accuracy was calculated per SP per case, separate for subscales of checklist items, overall across checklist items, and global ratings over time in the sequence of the role-play. This was subsequently averaged across cases, and descriptive statistics were calculated for each of the groups (RMV, PFV, RMV\&PFV and control). A one-way analysis of variance (ANOVA) for significance testing between groups, including a post hoc test, was conducted (all in SPSS 20). Further, the effect size (Cohen's d) was calculated based on the means and standard deviations between the groups.

\section{RESULTS}

Based on statistical comparison of the means (Table 3) between training methods, a single factor variance analysis between all the groups showed highly significant results in the overall mean score of the dichotomous checklist $\mathrm{p}<.001$ and in the overall total mean global rating $\mathrm{p}<.003$ against the control group. As each SP had four student encounters in a row ( $\mathrm{t} 1$ =first encounter to $\mathrm{t} 4=$ fourth and last encounter), we looked at the evolution over time of the mean scores. Compared to the control group, all total mean scores of the dichotomous checklist from the intervention groups (RMV, PFV, $\mathrm{RMV}+\mathrm{PFV}$ ) showed significant results against the control group for every step over time. For evolution over time, the mean scores of the global ratings were significantly different against the control-group for $\mathrm{t} 1$, $\mathrm{t} 3$ and $\mathrm{t} 4$ but not for $\mathrm{t} 2$. A post hoc calculation showed no significant results within the intervention groups and within the intervention groups over time (Figure 1 and 2).

In a second analysis step, the mean scores of the subscales (verbal, non-verbal, para-verbal and SP mentions only when asked) of the dichotomous checklists were calculated for groups and time. The overall mean for the subgroups over time t1-t4 also showed significantly better results against the control group. Subgroups: "verbal" $p<.001$, "non-verbal" $p<.001$, "para-verbal" $p<.033$ and "SP mentions only when asked" $p<.017$. The calculation of Cohen's $d$ based on the overall mean scores and standard deviations of the dichotomous checklist and the global rating between the control and the intervention groups showed large effect sizes. However, although differences be- 
tween the intervention groups show moderate effect sizes, they are not statistically significant (see Table 4).

Table 3: Overall mean score of the dichotomous checklist and the global rating

Overall mean score of the 27 item dichotomous checklist

\begin{tabular}{lll}
\hline Group & Mean & SD \\
\hline RMV\&PFV & 18.14 & 2.40 \\
PFV & 19.03 & 2.02 \\
RMV & 18.24 & 2.57 \\
Control Group & 12.28 & 3.02 \\
\hline
\end{tabular}

Overall mean score of the four-point global rating scale

\begin{tabular}{lll}
\hline Group & Mean & SD \\
\hline RMV\&PFV & 3.23 & 0.47 \\
PFV & 3.04 & 0.25 \\
RMV & 3.08 & 0.32 \\
Control Group & 2.60 & 0.52 \\
\hline
\end{tabular}

Table 4: Cohen's d overall score for the checklist and global rating Overall score checklist Cohen's d

\begin{tabular}{lllll}
\hline & Control Group (CG) & PFV & RMV & RMV\&PFV \\
\hline CG & $X$ & 2.625 & 2.121 & 2.147 \\
PFV & $X$ & $X$ & 0.341 & $0.398 \star$ \\
RMV & $X$ & $X$ & $X$ & 0.037 \\
\hline
\end{tabular}

Moderate effect

Overall global rating Cohen's d

\begin{tabular}{lllll}
\hline & Control Group (CG) & PFV & RMV & RMV\&PFV \\
\hline CG & $X$ & 1.079 & 1.120 & 1.255 \\
PFV & $X$ & $X$ & 0.141 & $0.476 \star$ \\
RMV & $X$ & $X$ & $X$ & $0.347 \star$ \\
\hline
\end{tabular}

Moderate effect 


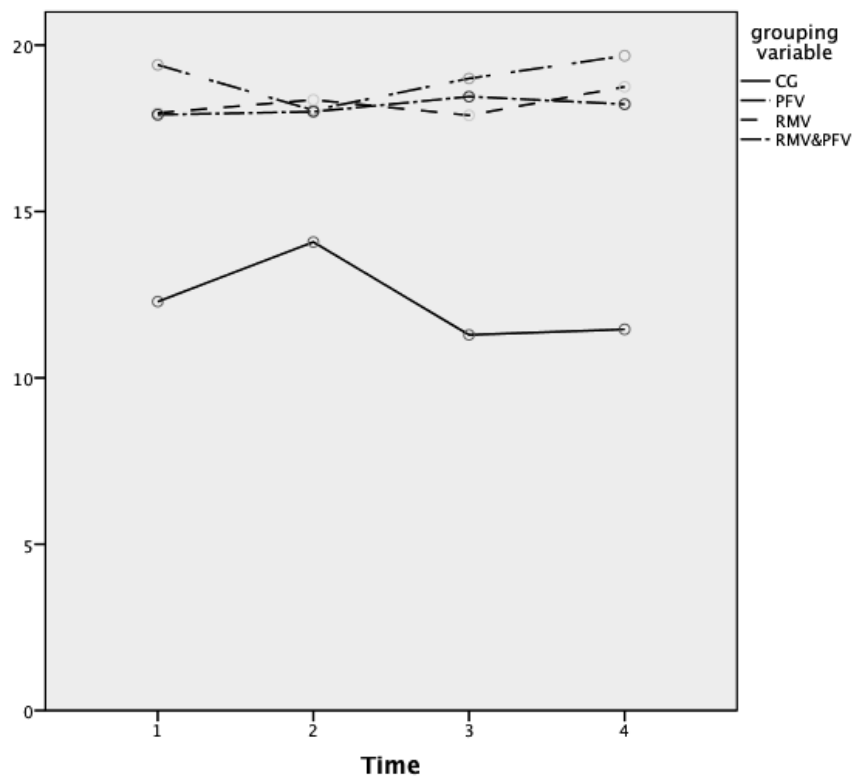

Figure 1: Total mean score dichotomous checklist (27 items) between all groups and over the sequence of time t1-t4

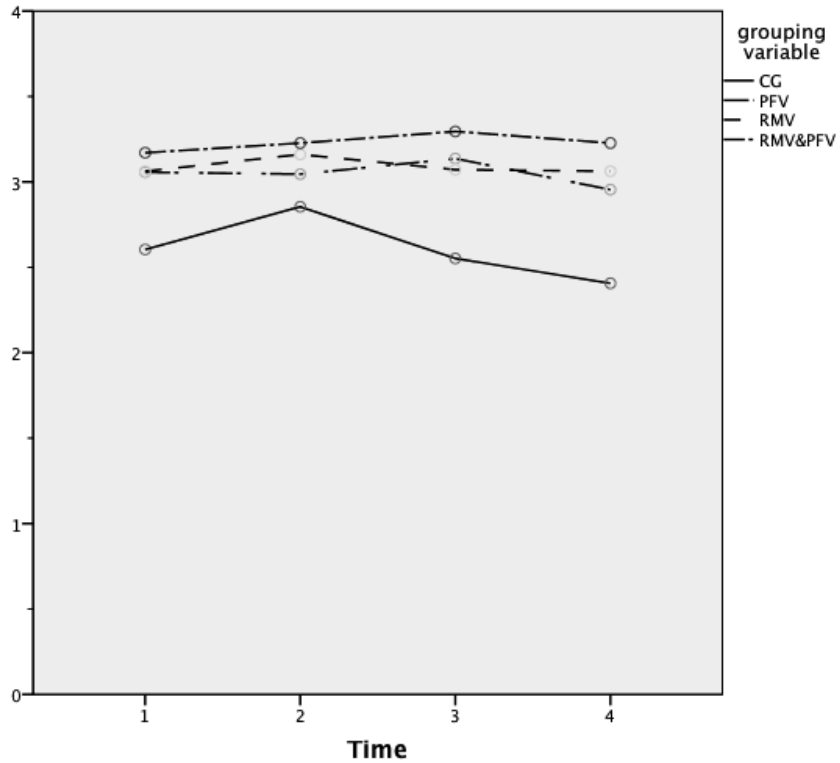

Figure 2: Total mean global rating (1 to 4$)$ between all groups and over the sequence of time t1-t4 


\section{DISCUSSION}

We compared three intervention groups of SPs with different forms of video training (RMV, PFV and the combination of RMV \& PFV) with a control group of SPs trained without video in terms of SP role accuracy. Our results indicate that SPs who were trained with video appear to perform better than SPs trained without video in terms of the accuracy of the SP performance over four sequential portrayals. This is in line with studies showing that video improves performance (15-17). The initial hypothesis that the combination of RMV \& PFV in SP training would improve the accuracy of the SP portrayal most was not confirmed, although the effect size is slightly larger with RMV (Table 2). The post hoc test conducted to find differences among the intervention groups showed no significant differences (Figure 1\&2). Our findings indicate therefore that any use of video has a substantial positive effect in SP training, either with RMV and/or PFV, and this even after one training session only. Berg (33) also observed in his study report that video is an important tool for learning because it is connected with emotions. In our study, the SPs of the intervention groups were working with video for the first time. Even if video training is a superior method with large potential effects, it also holds dangers. Fröhlich (34) warns that a first look at a video-recording of oneself could be a critical moment, since it forces a confrontation with self-concept. Accordingly, training SPs with video places particular responsibility on the SP trainer. However, by providing good information about the use of video in the selection process of SPs this danger can easily be diminished.

In our study we worked with novice SPs who had no experience as actors. According to Benner (35) SPs will develop expertise with continuous practice, so they will automatically be transformed from novices to experts. Future research will need to explore the effect of video on more experienced SPs.

Apart from the fact that we used inexperienced SPs, defining the optimal training time was also a challenge. The requirement for our SP training was role accuracy only, without any requirements for SP feedback, filling in checklists or writing comments on student's behaviour. In our research all groups received feedback from the SP trainer. In their literature review Hammoud et al. (36) emphasise that feedback based on video is a good tool for learning and predict that feedback from trained individuals promotes maximum effectiveness. Even SPs from the control group received feedback from the SP trainer, but their performance was less accurate. Hammoud et al. (36) suggest that the combination of feedback and video makes feedback unique because it allows the SP to look at him/herself from "outside", thereby rendering a realistic picture of their skills in context.

Several limitations of the current study should be pointed out. Firstly we were working with only four encounters per SP with 4 different nursing students and use of only one case, which is not typical for regular usage schemes of use of SPs. However, to answer our research question in a methodologically sound way this was the only 
feasible design. Future studies should investigate whether the accuracy still holds over a higher number of encounters. Also, more research should be done with a larger sample size, different cases and more SP/student encounters with SPs ranging in level of expertise.

Secondly we used only one training session that was limited to 90 minutes. A longer training time or more than one training session might have shown different effects on the SPs' accuracy of performance between and in the intervention groups.

We conclude that use of video during SP training e.g. for an OSCE enhances the accuracy of SP portrayal compared with no video, regardless of the type of video intervention used. 


\section{LITERATURE}

1. Tamblyn RM, Klass DJ, Schnabl GK, Kopelow ML. The accuracy of standardized patient presentation. Medical Education. 1991/03/01 ed1991. p. 100-9.

2. Barrows HS. An overview of the uses of standardized patients for teaching and evaluating clinical skills. Academic Medicine1993. p. 443-53.

3. Barrows HS, Williams RG, Moy RH. A comprehensive performance-based assessment of fourth-year students' clinical skills. Journal of Medical Education. 1987/10/01 ed1987. p. 805-9.

4. Norman GR, Tugwell P, Feightner JW. A comparison of resident performance on real and simulated patients. Journal of Medical Education. 1982/09/01 ed1982. p. 708-15.

5. Harden R, Stevenson M, Downie WW, Wilson GM. Assessment of clinical Competence using Objective Structured Clinical Examination. British Medical Journal. 1975;1(February):447-51.

6. Howley LD. Performance assessment in medical education: where we've been and where we're going. Eval Health Prof. [Review]. 2004 Sep;27(3):285-303.

7. Adamo G. Simulated and standardized patients in OSCEs: achievements and challenges 1992-2003. Medical Teacher. 2003 May;25(3):262-70.

8. Boulet JR, De Champlain AF, McKinley DW. Setting defensible performance standards on OSCEs and standardized patient examinations. Medical Teacher. 2003 May;25(3):245-9.

9. Hodges B, Mcllroy JH. Analytic global OSCE rating sensitive to level of training. Medical Education. 2003;37:1012-6.

10. Hatala R, Marr S, Cuncic C, Bacchus CM. Modification of an OSCE format to enhance patient continuity in a high-stakes assessment of clinical performance. BMC Medical Education. [Research Support, NonU.S. Gov't]. 2011;11:23.

11. Cleland J, Abe K, Rethans J. The Use of Simulated Patients in Medical Education. In: Education AGiM, editor. Dundee: AMEE Guide; 2010.

12. Dudley F. The Simulated Patient Handbook. London, New York: Radcliffe Publishing; 2012.

13. Errichetti A, Boulet JR. Comparing traditional and computer-based training methods for standardized patients. Acad Med. [Randomized Controlled Trial]. 2006 Oct;81(10 Suppl):S91-4.

14. Cossmann PH. Video-coaching as biofeedback tool to improve gated treatments: Possibilities and limitations. Z Med Phys. 2012 Sep;22(3):224-30.

15. Shippey SH, Chen TL, Chou B, Knoepp LR, Bowen CW, Handa VL. Teaching subcuticular suturing to medical students: video versus expert instructor feedback. J Surg Educ. [Randomized Controlled Trial Research Support, Non-U.S. Gov't]. 2011 Sep-Oct;68(5):397-402.

16. Gupta G, Sehgal S. Comparative effectiveness of videotape and handout mode of instructions for teaching exercises: skill retention in normal children. Pediatr Rheumatol Online J. 2012;10(1):4.

17. Hu YY, Peyre SE, Arriaga AF, Osteen RT, Corso KA, Weiser TG, et al. Postgame analysis: using videobased coaching for continuous professional development. J Am Coll Surg. [Research Support, N.I.H., Extramural Research Support, Non-U.S. Gov't]. 2012 Jan;214(1):115-24.

18. Scherer LA, Chang MC, Meredith JW, Battistella FD. Videotape review leads to rapid and sustained learning. Am J Surg. [Comparative Study Evaluation Studies]. 2003 Jun;185(6):516-20.

19. Parsons JL, Alexander M, L.,L.,. Modifying spike jump landing biomechanics in female adolescent volleyball athletes using video and verbal feedback. Journal of Strengh and Conditioning Research. 2012;28(4):1076-84.

20. Thistlethwaite J, Ridgway G. Making it Real. Oxon: Radcliffe Publishing; 2006.

21. Shirazi M, Sadeghi M, Emami A, Kashani AS, Parikh S, Alaeddini F, et al. Training and validation of standardized patients for unannounced assessment of physicians' management of depression. Acad Psychiatry. 2011 Nov 1;35(6):382-7.

22. McNaughton N, Ravitz P, Wadell A, Hodges BD. Psychiatric education and simulation: a review of the literature. Can J Psychiatry. [Review]. 2008 Feb;53(2):85-93. 


\section{CHAPTER 2}

23. Cohn R. Von der Psycholoanalyse zur Themenzentrierten Interaktion. Von der Behandlung einzelner zu einer Pädagogik für alle. Stutgart: Klett-Cotta; 1975.

24. Wallace P. Coaching standardized patients for use in assessment of clinical competence. New York: Springer Publishing Company; 2007.

25. Campell S, H.,, Daley K, M., . Simulation Scenarios for Nurse Educators. New York: Springer Publishing Company; 2009.

26. Barrows HS. Training Standardized Patients to have physical findings. Chicago: Southern Illinois University School of Medicine; 1999.

27. Carnicke S. Stanislavsky in Focus: An Acting Master for the Twenty-First Century. Theatre Classics. 2008:221.

28. Raymond DD, Dorwick PW, Kleinke CL. Affectuve responses to seeing oneself for the first time on unedited videotape. In: Quaterly CP, editor.: Counseling Psychology Quaterly; 1993. p. 193-200.

29. Sibbald M, Cavalcanti RB. The biasing effect of clinical history on physical examination diagnostic accuracy. Medical Education. [Research Support, Non-U.S. Gov't]. 2011 Aug;45(8):827-34.

30. Graber ML, Franklin N, Gordon R. Diagnostic error in internal medicine. Arch Intern Med. [Comparative Study Research Support, Non-U.S. Gov't]. 2005 Jul 11;165(13):1493-9.

31. Buchner A. G*Power 3. [http://www.psycho.uni-duesseldorf.de/abteilungen/aap/gpower3/] Düsseldorf: Heinrich Heine Universität; 2012 [updated 20.08.2012; cited 2013 28.10.].

32. Bortz J, Dörung N. Forschungsmethoden und Evaluation. Heidelberg: Springer; 2005.

33. Berg M. Lernen durch Spiegelhormone. München2010.

34. Fröhlich WD. Wörterbuch zur Psychologie. München: DTV; 1987.

35. Benner PE. From novice to expert: excellence and power in clinical nursing practice. Chicago: Prentice Hall; 2001.

36. Hammoud MM, Morgan HK, Edwards ME, Lyon JA, White C. Is video review of patient encounters an effective tool for medical student learning? A review of the literature. Adv Med Educ Pract. 2012;3:19-30. 


\section{CHAPTER 3}

Validity evidence and reliability of a Simulated Patient feedback instrument

Claudia Schlegel

Ulrich Woermann

Rethans Jan-Joost

Van der Vleuten Cees P.M.

BMC Medical Education 2012; 12(6): e1-5 


\section{ABSTRACT}

\section{Background}

In the training of healthcare professionals, one of the advantages of communication training with simulated patients (SPS) is the SP's ability to provide direct feedback to students after a simulated clinical encounter. The quality of SP feedback must be monitored, especially because it is well known that feedback can have a profound effect on student performance. Due to the current lack of valid and reliable instruments to assess the quality of SP feedback, our study examined the validity and reliability of one potential instrument, the 'modified Quality of Simulated Patient Feedback Form' (mQSF).

\section{Methods}

Content validity of the MQSF was assessed by inviting experts in the area of simulated clinical encounters to rate the importance of the mQSF items. Moreover, generalizability theory was used to examine the reliability of the mQSF. Our data came from videotapes of clinical encounters between six simulated patients and six students and the ensuing feedback from the SPs to the students. Ten faculty members judged the SP feedback according to the items on the mQSF. Three weeks later, this procedure was repeated with the same faculty members and recordings.

\section{Results}

All but two items of the mQSF received importance ratings of $>2.5$ on a four-point rating scale. A generalizability coefficient of 0.77 was established with two judges observing one encounter.

\section{Conclusions}

The findings for content validity and reliability with two judges suggest that the mQSF is a valid and reliable instrument to assess the quality of feedback provided by simulated patients. 


\section{BACKGROUND}

A major advantage of communication training with simulated patients (SPs) in the training of healthcare professionals is that SPs are able to provide feedback to students from a patient's perspective immediately after a simulated clinical encounter (SCE) [1-3]. Feedback is an important and valuable tool in interactive learning [4], and for our purposes, it may be defined as the provision of specific information on a student's performance relative to a specific performance standard [5], with the intention of improving the student's performance. High-quality feedback can have a profound effect on student performance [6] and is, therefore, vital to the overall effectiveness of a training sequence.

To assess the quality of SP feedback, a valid and reliable assessment instrument is needed. The only existing instrument, the "Maastricht Assessment of Simulated Patients" (MaSP) [7], has two subscales and assesses both the quality of SP feedback and the authenticity of SP performance during a simulated consultation; as a result, it is not detailed enough to assess the quality of SP feedback in-depth. At the same time, some items of the MaSP, e.g. "SP left the room between consultation and feedback", are too specific and irrelevant for institutions where the SP stays in the room between encounter and feedback.

In the "grey literature", we found another instrument, the "Quality of Simulated Patient Feedback (QSF) Form" [8], which was designed to help SP trainers to evaluate the quality of the oral SP feedback process and thus to determine whether SPs need more training in oral feedback. The detailed items of this instrument meet our needs, but the form has never been validated and there are no data on its reliability. The QSF is an 18-item questionnaire (Table 1) with a dichotomous checklist based on the tenets of basic feedback rules [9-11]. For our purpose, the dichotomous rating options were expanded to a four-point rating scale (c.f. the method section for reasons). The aim of our study, then, was to gather evidence on the validity and reliability of the mQSF when used to assess the quality of feedback provided by SPs.

\section{METHODS}

The study was conducted at a school of nursing in Berne, Switzerland, with nursing students in their second of three curricular years. The two-step approach of the study consisted, first, of an evaluation of the evidence for content validity, and second, of a generalizability analysis to estimate the reliability of the instrument.

\section{Forward-backward translation of the questionnaire}

Since the study was conducted in a German-speaking country, the English QSF had to be translated into German. We used a forward-backward translation approach, which is 
recommended for translating test instruments [12]. Using this approach, a native speaker of the target language (in our case German) translated the instrument from the source language (English), and another person fluent in English then translated the text back from German into English. The original and the back-translated versions were then compared to ensure that the meaning and the nuances of the text were conserved.

\section{Evidence for the content validity of the MQSF items}

The content validity of the 18 mQSF items was ascertained by asking 25 medical and nursing education experts from Switzerland, Germany and Austria to rank the importance of each item on a four-point rating scale ( 1 = not at all important; 4 = very important), using an online survey tool. An even number of scale points (no "neutral" middle position) was used to force clear ratings. The experts were alumni of the Master of Medical Education Program at the University of Berne, Switzerland, who were actively involved in SP programs at their own institutions. They were also invited to comment on the mQSF, e.g. whether they thought additional items should be added.

Moreover, since the items were rated on an ordinal rating scale, both mean and median ratings were calculated. Further, Cronbach's $\alpha$ was calculated to ascertain homogeneity among raters. An item-total correlation was performed to check whether any item is inconsistent with the rest of the scale and would thus have to be discarded.

We considered the relevance of an item of the mQSF as most important. If the mean of such an item was below 2.5 we studied the item-correlation of that item in more detail and decided to withdrew that item if a negative item-total correlation was present.

\section{Reliability of the MQSF}

We were interested in the reliability of the quality of the SP feedback and of how the quality might be increased, e.g. by having more than one judge rating the quality. For this purpose, an analysis of generalizability (using Genova [13]) was used; reliability estimates were based on a partitioning into true and multiple sources of error variance.

Six SPs were videotaped during eight clinical encounters with different students; at the end of each encounter, feedback was given by the SPs. One videotaped encounter per SP was randomly selected for assessment by ten faculty members who judged the feedbacks according to the mQSF items. The six SPs, four females and two males, had at least 1 year of experience in role-playing and giving feedback. Three SPs impersonated a case of acute postoperative pain after an open appendectomy and were instructed to act as if they were afraid that something had gone wrong during the operation. The other three SPs enacted the role of a patient in a consultation on oral anticoagulation therapy after aortic valve replacement; they were instructed to act as if they were indifferent toward the information they received. All SP clinical encounters used 
and recorded in this investigation were specifically designed for this purpose and in line with the heretofore-acquired curricular competences.

In the G-study, the quality of feedback given in these six encounters was rated by 10 judges (teachers from our institution who were trained in the use of the mQSF) using a rating scale for the mQSF that ranged from 1 (=strongly agree) to 4 (=strongly disagree). We expanded the originally dichotomous rating options to a four-point rating scale because we wanted to provide more subtle parameters for the assessment of SP performance in terms of qualitative holistic judgments [14]. Three weeks later, the procedure was repeated with the same ten teachers and the same six recorded SCEs. We thus had a fully-crossed Video (encounter) by Rater by Occasion $(6 \times 10 \times 2)$ design in which we treated all facets as random.

In the subsequent decision-study (D-study), the facet "V" (video) of a CD-recorded clinical encounter was the object of measurement, whereas the number ( $n$ ) of judges (facet J) and occasions (facet $\mathrm{O}$ ) were varied (Figure 1).

$$
r_{t t}=\frac{V}{V+J / n_{j}+O / n_{o}+V J / n_{j}+V O / n_{o}+(V J O+e) /\left(n_{j} \times n_{o}\right)}
$$

Figure 1: The object of measurement for the D-study. Facet " $V$ " (video), of a CD-recorded clinical encounter, number $(n)$ of judges (facet J), occasions (facet $O$ )

\section{Ethical considerations}

Ethical approval was sought from the ethics committee of the State of Bern, Switzerland. Informed consent was obtained from all participating students and SPs. Participation in the study was completely voluntary. All participants were free to leave the study at any time without any repercussions. There was no financial compensation.

\section{RESULTS}

\section{Forward-backward translation}

The comparison of the original source text of the QSF and the retranslated text revealed no major discrepancies.

\section{Evidence of content validity of the MQSF items}

Of the 25 experts invited to participate in the study, 14 completed the questionnaire (response rate 56\%). The importance rates of the mQSF items from the experts were $>2.5$ on a four-point rating scale for all but two items. The highest ratings were those 
for items 7, 8, and 10 (mean $=3.86(S D=0.53)$, median $=3.96)$, whereas the lowest ratings were those for items 12 (mean $=2.43(S D=1.28)$, median $=2.10$ ) and 18 (mean $=2.43(\mathrm{SD}=1.09)$, median 2.13) (Table 1).

Table 1: Experts' judgments of the importance of the QSF items

\begin{tabular}{|c|c|c|c|c|c|}
\hline No & Item & Mean & $\begin{array}{l}\text { Standard } \\
\text { deviation }\end{array}$ & Median & $\begin{array}{l}\text { Item-total } \\
\text { correlation }\end{array}$ \\
\hline 1 & SP: So, how do you think it went? & 3 & 1.11 & 3.25 & 0.23 \\
\hline 2 & $\begin{array}{l}\text { SP: So, what are some things you think you did } \\
\text { well? }\end{array}$ & 3.36 & 1.08 & 3.72 & 0.28 \\
\hline 3 & $\begin{array}{l}\mathrm{SP}: \text { Is there anything you would do or say } \\
\text { differently, if you could do this again? }\end{array}$ & 3.36 & 0.93 & 3.63 & 0.65 \\
\hline 4 & $\begin{array}{l}\text { SP gave student adequate time to answer } \\
\text { questions before continuing }\end{array}$ & 3.36 & 0.93 & 3.63 & 0.73 \\
\hline 5 & SP first gave positive feedback & 3.14 & 1.13 & 3.63 & -0.13 \\
\hline 6 & $\begin{array}{l}\text { SP's positive feedback referred to specific } \\
\text { changeable behaviours }\end{array}$ & 2.93 & 1.14 & 3.00 & 0.70 \\
\hline 7 & SP gave feedback from patient's perspective & 3.86 & 0.53 & 3.96 & 0.22 \\
\hline 8 & $\begin{array}{l}\text { SP`s negative feedback referred to specific } \\
\text { changeable behaviours (feedback was not } \\
\text { destructive) }\end{array}$ & 3.86 & 0.53 & 3.96 & 0.09 \\
\hline 9 & $\begin{array}{l}\text { SP limited the constructive feedback to } 2 \text { or } \\
\text { fewer points }\end{array}$ & 2.86 & 1.13 & 2.38 & 0.33 \\
\hline 10 & $\begin{array}{l}\text { SP gave constructive feedback from patient`s } \\
\text { perspective }\end{array}$ & 3.86 & 0.53 & 3.96 & 0.22 \\
\hline 11 & $\begin{array}{l}\text { SP stopped feedback and acknowledged student's } \\
\text { feelings }\end{array}$ & 5.79 & 1.12 & 2.36 & 0.30 \\
\hline 12 & SP confirmed the feelings with student & 2.43 & 1.28 & 2.10 & 0.74 \\
\hline 13 & SP reassured student about purpose of feedback & 3.14 & 1.03 & 3.63 & 0.60 \\
\hline 14 & SP finished feedback on a positive note & 2.57 & 0.94 & 2.20 & 0.71 \\
\hline 15 & SP asked student to summarize feedback given & 2.86 & 1.23 & 3.00 & 0.33 \\
\hline 16 & $\begin{array}{l}\text { The SP ensured that the student understood } \\
\text { what she (the student) needed to work on }\end{array}$ & 2.79 & 1.31 & 3.00 & 0.36 \\
\hline 17 & $\begin{array}{l}\text { SP continued to ask student if she had questions } \\
\text { until student said "no" }\end{array}$ & 2.79 & 1.12 & 2.36 & 0.43 \\
\hline 18 & SP thanked the student & 2.43 & 1.09 & 2.13 & -0.18 \\
\hline
\end{tabular}

The items were largely, albeit not completely, homogeneous for all judges, with a Cronbach's $\alpha$ of 0.78 . As for the item-total correlation, items 5 and 18 showed negative correlations with the overall score. The latter item was also rated with a mean $<2.5$, which is why we excluded it. Without item 18 , the internal consistency (Cronbach's $\alpha$ ) increased from 0.78 to 0.80 . None of the experts gave comments on adding new, or modifying existing, items. 


\section{Reliability of the MQSF}

All simulated clinical encounters, including the feedback part, were conducted and recorded successfully.

The estimated variance components that resulted from the analysis of variance are given in Table 2. Most of the variance can be explained as systematic differences between videos (70\%). Being the object of measurement, this represents the true score variation. The general error term is the largest source of error, followed by systematic variation between the raters (rater leniency/stringency; nearly $8 \%$ ) and rater by video variation (rater leniency/stringency for some videos, but not for others; $16 \%$ ). All occasion-related components are small, indicating a high intra-rater consistency.

Table 2: Estimated variance components

\begin{tabular}{llcc}
\hline & \multicolumn{2}{l}{ Variance components } \\
\cline { 2 - 4 } Source & Estimate & Error & \% of total variance \\
\hline V & 79.390 & 43.905 & 70.33 \\
$J$ & 8.714 & 6.279 & 7.72 \\
O & 0.714 & 1.035 & 0.63 \\
VJ & 18.198 & 5.957 & 16.12 \\
VO & 0.000 & 0.867 & 0.00 \\
JO & 2.069 & 2.276 & 1.83 \\
VJO & 18.363 & 3.788 & 16.27 \\
\hline
\end{tabular}

$\checkmark$ video, $J$ judges, $O$ occasions

Using these variance components, we got a domain-referenced dependability coefficient of 0.633 was calculated by using one judge on one occasion using the formula expressing the composition of the sources of error variance divided by their respective sample size ( $\mathrm{n}$ ) (Figure 1).

The judge-related components are rather large, which means that sampling more judges would increase reliability. On the other hand, repeated judgments would hardly result in increased reliability, given the small variance component of 0.71 for facet 0 (occasion).

The following estimates of the dependability coefficient were calculated running Dstudies for varying numbers of judges and occasions (Table 3 ).

Table 3: Number of judges, occasions and reliability

\begin{tabular}{llll}
\hline & 1 judge & 2 judges & 3 judges \\
\hline 1 occasion & 0.63 & 0.77 & 0.83 \\
2 occasions & 0.68 & 0.81 & 0.86 \\
3 occasions & 0.70 & 0.83 & 0.88 \\
\hline
\end{tabular}




\section{DISCUSSION}

\section{Evidence of content validity of the MQSF}

Consistently positive expert ratings appear to support the conclusion that the mQSF has adequate content validity. Cronbach's $\alpha$ with 17 items was 0.80 , which suggests a high degree of rater homogeneity.

Correlations among items were positive, except for items 5 and 18 . However, these two items differed with regard to importance, which was rated quite high for item 5 but low for item 18 (Table 1). Item 5 ("SP gave first positive feedback") relates to an essential feedback rule (sandwich technique, [15]) which holds that starting with positive feedback creates an open mind-set in the recipient of the feedback. Item 18 ("SP thanked the student"), on the other hand, addresses a cultural peculiarity. Lauffs et al. (2008) [16] state that it is not only necessary to translate an instrument from one language into another, but also to adapt it culturally. At institutions where thanking students at the end of a feedback session is not customary, item 18 should indeed be removed from the QSF as we did.

Item 12 ("SP confirmed the feelings with student") had the lowest mean and median for importance ratings (Table 1), but showed the highest correlation with the overall score. Moreover, the importance of emphasizing students' feelings has been underlined by Steinwachs (1992) [17] who stated that strong feelings of students should be addressed.

\section{Reliability of the MQSF}

The G-study shows that increasing the number of judges observing an SP giving oral feedback increases the generalizability coefficient. A realistic design would include one judge and one occasion. In our decision study, this yielded a generalizability coefficient of 0.63 . Since individual judges are likely to be subjective in their judgments and can introduce substantial error variance, it seemed advisable to use more than one judge. In fact, with two judges, the generalizability coefficient increased from 0.63 to 0.77 . This indicates that two judges should observe the same encounter if possible.

\section{Limitations}

A limitation of our study is that the original instrument was translated into another language. Translating an instrument always involves the risk that the original idea expressed in an item may not be conveyed fully and accurately. Cultural differences can also hamper accurate representation of item content. A further limitation is that only content validity was explored and not other types of validity, but we studied the con- 
tent validity of this instrument because without content validity, other types of validity are meaningless.

While 14 raters seem sufficient to determine content validity [18], the generalizability study involved a rather low number of simulated clinical encounters; this was due to limited resources. However, a small sample size may be problematic with respect to representatively as it limits the generalizability to other settings and the confidence in the results of the G-study. Moreover, in our study, only one encounter, one case and one student per participating SP was rated. It would be interesting to explore case variability in SP feedback in future research.

\section{Conclusions}

The findings for content validity and reliability with two judges suggest that the mQSF is a valid and reliable instrument to assess the quality of feedback provided by simulated patients.

We recommend that more studies be conducted, with larger samples, more cases, and more students to corroborate the findings reported here. Such studies should include more encounters and compare results obtained with the mQSF with results obtained with the feedback quality component of the MaSP or other instruments for the assessment of feedback quality. 


\section{CHAPTER 3}

\section{LITERATURE}

1. Ryan A, Walshe A, Gaffney R, Shanks A, Burgoyne L, Wiskin C: Using standardized patients to assass communication skills in medical and nursing education. BMC Med Educ 2010, 10(24):1-8

2. Bosse HM, Nickel M, Huwendiek S, Junger J, Schultz JH, Nikendei C: Peer role-play and standardised patients in communication training: a comparative study on the student perspective on acceptability, realism, and perceived effect. BMC Med Educ 2010, 10:27.

3. Bokken L, Linssen T, Scherpbier A, van der Vleuten CPM, Rethans J: Feedack by simulated patients in undergraduate medical education: a systemic review of the literature. Med Educ 2009, 43(11):202210.

4. Holzinger A, Kickmeier MD, Wassertheurer S, Hessinger M: Learning performance with interactive simulations in medical education: lessons learned from results of learning complex physiologicyl models with the HAEMOdynamics SIMulator. Comput Educ 2009, 52 (1):292-301

5. van de Ridder JMM, Stokking KM, McGaghie W, ten Cate OTJ: What is feedback in clinical education? Med Educ 2008, 42:189-197.

6. Shute VJ: Focus on formative feedback. Rev Educ Res 2008, 78(1):153-189.

7. Wind LA, Van Dalen J, Muijtjens AMM, Rethans J: Assessing simulated patients in an educational setting: the MaSP (Maastricht Assessment of Simulated Patients). Med Educ 2004, 38:39-44.

8. May W, Fisher D: Training to standardize feedback. In 2nd International skills conference. Prato, Italy: Monash University; 2007.

9. Gordon J: One to one teaching and feedback. BMJ 2003, 326:543-545.

10. Claiborn C, Goodyear R, Horner P: Feedback. Psychother, Theory, Res, Pract, Train 2001, 38(4):401-405.

11. Branch W, Paranajape A: Feedback and reflection: teaching methods for clinical settings. Acad Med 2002, 77(12):1185-1188.

12. Monti F, Lupi F, Gobbi F, Agostini F, Miano A, Gee L, Abbott J: Validation of the Italian version of the cystic fibrosis quality of life questionnaire (CFQoL), a disease specific measure for adults and adolescents with cystic fibrosis. J Cyst Fibros 2007, in press.

13. Brennan RL: Elements of generalizability theory. lowa City,: American College Testing Program; 1983.

14. Streiner DL, Norman GR: Health Measurement. Fourth edition edition. Oxford: Oxford University Press; 2008.

15. Trembley P: Feed me back. IJO 2008, 19(2):33.

16. Lauffs M, Ponzer S, Saboonchi F, Lonka K, Hylin U, Mattiasson AK: Corss-cultural adaption of the Swedish version of readiness for interprofessional learning scale. Med Educ 2008, 42:405-411.

17. Steinwachs B: How to facilitate a debriefing. Simul Gaming 1992, 23(2):186-195.

18. Malmgreen C: Validating Research Instruments. Pensacola FL: National Nursing Staff Development Organization NNSDO; 2005. 


\section{CHAPTER 4}

The impact of communication training on real practice performance: A comparison of the effectiveness of a role-play module vs. a standardized-patient module in nursing education

Schlegel Claudia

Woermann Ulrich

Shaha Maya

Rethans Jan-Joost

Van der Vleuten Cees P.M.

Journal of Nursing Education 2012; 51(1): 16-22 


\section{ABSTRACT}

\section{Introduction}

Few studies have compared the effect of using SPs and role-plays in training communication skills in nursing education. We investigated the effectiveness of modules involving SPs and role-plays. The SP module involved SPs and an OSCE assessment whereas the role-play module consisted of peer role-plays and a written exam.

\section{Method}

A randomized post-test-only control group design with first-year nursing students was employed. The intervention group received one-to-one communication training with direct oral feedback from the SP. The control group had a training session with peer role-playing and mutual feedback. In a post-test at the start of their first clinical practice rotation, 55 students rated their self-efficacy. Real patients and clinical supervisors evaluated 26 students` communication skills during clinical practice.

\section{Results}

No significant differences were found between the intervention and control group in perceived self-efficacy and patient ratings. However, the clinical supervisors rated the communication skills of the students of the intervention group to be significantly $(p<0.0001)$ superior to the control group.

\section{Conclusion}

Judgements by clinical supervisors indicate that communication training modules including SPs and an OSCE are superior to communication training modules with peer role-playing. 


\section{INTRODUCTION}

Communication skills are of paramount importance for healthcare professionals (nurses, medical doctors, etc.) working with patients. Kurtz, Silverman, \& Draper, (2005), argue that without appropriate communication skills, the better part of the clinical efforts in medical care may be wasted. It has been demonstrated that patient-centered communication improves diagnostic efficiency (Epstein et al., 2005) physicians' and patients' satisfaction (May, Park, \& Lee, 2009) and treatment outcomes (Simpson et al., 1991; Stewart, 2001). As a result, communication skills training (CST) has become an essential component of many curricula in the education of healthcare professionals (Snadden \& Ker, 2005).

There is ample evidence that communication skills training indeed improves healthcare professionals' communicative competence (Bokken, Linssen, Scherpbier, van der Vleuten, \& Rethans, 2009; Browning, Meyer, Truog, \& Solomon, 2007), but training methods vary. CST with peer role-playing is a widely used method with proven effectiveness (Dent \& Harden, 2005; Nestel \& Tierney, 2007). It has the important advantage that it can be implemented with few resources beyond those available for regular training. Communication skills training with standardized patients (SPs) has also been shown to be effective (Dent \& Harden, 2005; Kurtz, et al., 2005; May, et al., 2009), but it is more complex and more expensive.

Several studies have compared two teaching methods using SPs and peer roleplaying (traditional method) and examined their effects on student nurses and medical students (Becker, Rose, Berg, Park, 2006; Bosse et al., 2010; Moon 2003). Nevertheless, Lane \& Rollnick, (2005) concluded, after a review of the literature on the use of SPs and role-play in communication skills training, that more studies are needed to compare the two methods. In general, the published studies relied on the SPs assessment of the quality of students' communication skills in vitro, i.e. within the training setting. The students' communication skills were not evaluated by real patients, the students themselves or clinical supervisors in vivo, i.e. in the real world (in a healthcare setting). The assessment of the effectiveness of communication training modules may gain new dimensions by incorporating the perspective of real patients, students and supervisors (trained nurses, who work together with the students during their practical rotation in hospital). Therefore, it was essential to compare and evaluate the effects of communication skills training modules with and without the use of SPs in the real clinical practice. To date, modules where SPs have been involved were assessed at the end of the module by written or oral exams. It was, therefore considered essential to investigate the effectiveness of a CST module with SPs in combination with an Objective Structured Clinical Examination (Objective Structured Clinical Examination (OSCE) in comparison with traditional approaches in CST that includes written assessment.

Our study compared the effectiveness of CST with a peer role-play module followed by a summative written test versus CST with an SP module including a perfor- 
mance-based test (OSCE). The respective effectiveness was evaluated by (a) students in terms of perceived self-efficacy, (b) patients in terms of their perception of the students' communication skills, and (c) clinical supervisors in terms of a judgment of the students' communication skills. We hypothesized that a combined training (CST with SP) including an assessment (OSCE with SPs) would lead to better results on all three points of measurement in clinical practice. However, compelling evidence of the superiority of the use of SPs in a CST module is required to justify the higher implementation effort.

\section{METHODS}

\section{Participants and setting}

The participants were first-year students in the program of the Educational Centre of Nursing in Berne, Switzerland. The students were between 18 and 20 years old and had no previous experience as nurses in a hospital. To be accepted into the program, all students had undergone the same admission procedure, which involved a structured interview with two faculty members. The four sub-categories of this 14-item standardized interview addressed self-competence, social competence, professional competence and motivation to become a nurse. The two faculty members scored each student on a response scale from 0-3. To pass the interview, a minimum total score of 28 points (averaged between the two raters) and no item rated zero were necessary.

After acceptance into the program, the students were assigned to one of two different school sites using random numbers generated by Microsoft's office excel program. The nursing program is offered at two different sites within the city of Berne, Switzerland, which offer an identical curriculum taught by the same teachers with the exception, for research purposes, of the CST module. The students on one campus represented the intervention group; the students in the other were the control group. To determine whether the students in the intervention group differed from the control group, a t-test of the admission test scores was conducted and control and intervention group did not differ $(p=0.993)$.

For the purpose of the study, we used a randomized post-test-only control-group design (see Figure 1). 


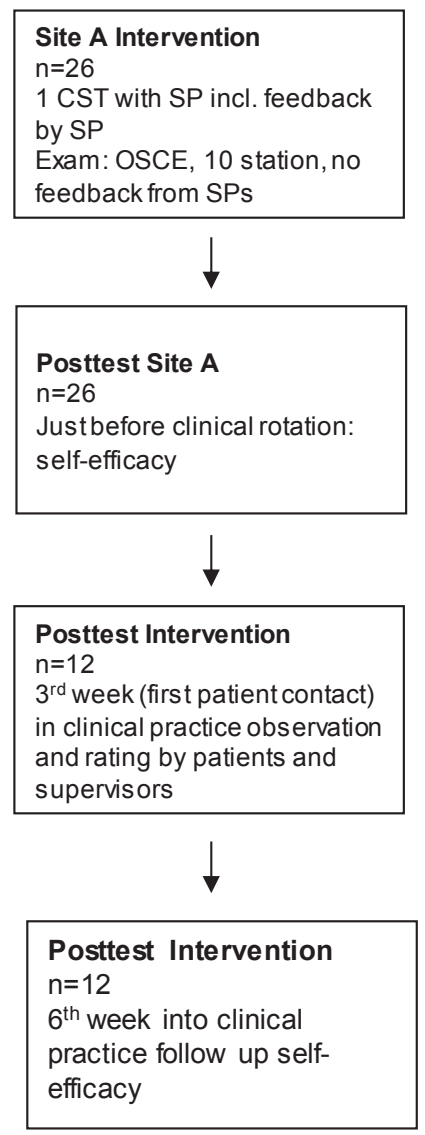

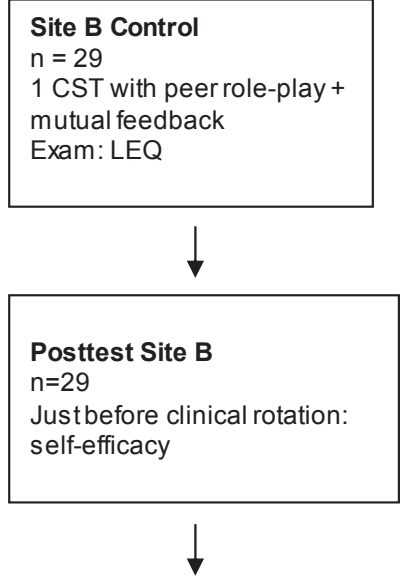

Posttest Control
$n=14$
$3^{\text {rd }}$ week (first patient contact)
in clinical practice observation
and rating by patients and
supervisors

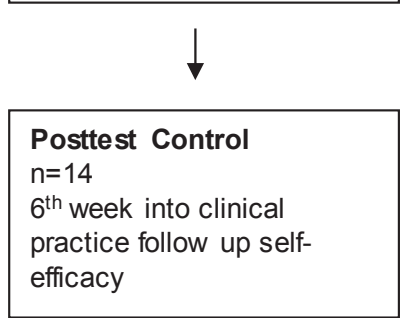

Figure 1: The study design

All students had attended the same six-month introductory program before participating in the study. One of the ten modules in the introductory program was 'Basics of communication', which was scheduled two months before the start of the clinical practices at both school sites. As a part of this module, students of both groups (intervention and control) attended five hours of lectures and training on feedback and feedback rules.

\section{The SP module for CST}

On one day during the module, each student of the intervention group participated in a simulated clinical encounter (SCE) with an SP. On the day before they had received a 15 -minute briefing from a faculty member about the program. The task was to conduct a pain assessment with a patient with arthritis. The students had to assess (1) the location of the pain, (2) its quality, (3) its intensity, (4) if the pain interfered with the pa- 
tient's normal everyday activities, and (5) to what extend much the pain treatment had relieved the pain. Students used the template of the Swiss Cancer Society pain assessment. The day of the intervention, each student was given 15 minutes to read the case and prepare for the encounter with the SP. The one-to-one training with the SP lasted 20 minutes and was followed by oral feedback by the SP directly after the encounter. Six SPs, all females aged between 40 and 50, took part in four to five clinical encounters with different students of the intervention group. SP role and feedback were trained (one hour for the role, one hour for the feedback) according to the standards set by Wallace, (2007). SPs had done one SCE previously but the role of the pain patient was new for them.

\section{The role-play module for CST}

At the same time, at the other school site, the control group took part in a traditional CS training session involving peer role-playing and mutual feedback. Here, too, the students had received a 15- minute briefing the day before. The task and patient case were the same as in the intervention group. On the day of the role-play, faculty trained students in role-play and feedback for two hours. The students were also asked to use their knowledge from the lectures and training on feedback and feedback rules they had attended a few weeks earlier in the module. Before the actual peer role-play, the students were also given 15 minutes to read the case and prepare their role-play and the feedback.

Subsequently, groups of three students had one hour (20 minutes per student) to take turns playing patient, nurse and observer. A round of mutual feedback along the lines of standardized feedback criteria followed each round of role-play.

The feedback criteria for the SPs in the intervention group and for the students in the control group were identical. These criteria included items on basics of communication skills such as "student has eye contact with the patient", "student talks in direction of patient", "student formulates sentences which are easy to understand", "student explains technical terms to the patient", "student invites patients to ask questions", "student answers the patient's questions politely", "student uses words that are easy to understand for the patient".

\section{Assessment of the two groups}

A summative assessment of the communication skills training was carried out after each module. For the CST module with SPs, a 10-station OSCE was used to assess the intervention group. During the OSCE, the students received no feedback from SPs or faculty. The control group (role-play module) took a written exam in the form of Long Essay Questions (LEQ). A long essay question is an assessment method for complex learning situations. The question contains phrases such as "Describe the management 
of a patient with post operative pain" (Amin \& Chong 2006). Both assessments lasted 90 minutes.

\section{Outcomes}

We measured self-efficacy in a post-test and a follow-up test as suggested by Blok et al.,(2004). Blok's Self-Efficacy Questionnaire of the European Donor Hospital Education Program (EDHEP) was adapted by replacing the donor-related terminology by adequate phrases for nursing situation. In the post-test, all 55 participating students of both groups completed the questionnaire directly before the start of their first sixmonth rotation as student nurses. The same questionnaire was used for the follow-up test, which was conducted six weeks into the rotation when the students returned to the school for one day. The follow-up test it was given to explore differences between the intervention and control groups regarding an expected increase in self-efficacy. Since anonymity was required for ethical reasons (see below), the students were instructed to choose a nickname to sign the post-test. The students were asked to use the same nickname consistently to allow for questionnaire matching.

For the clinical rotation, the nursing students were randomly assigned to different hospitals and wards the of Berne area. The clinical internship started with a two-week introductory course with no patient contact. In the third week, students started working with patients. At this point, i.e. the third week into the rotation, various patients and supervising nurses repeatedly assessed the students' communication skills. These supervising nurses were fully qualified and had at least two years of practice experience on the respective ward. Each supervising nurse was responsible to enhance the student learning experience and generally worked alongside when they worked with patients. Time and place of the assessments by the various patients and supervising nurses were not announced in advance; the students only knew that the assessments would take place in this third week. After each patient encounter, patient and observing supervising nurses completed their assessment forms. It was not disclosed to the supervising nurses and the patients whether the student belonged to the intervention or control group. In fact, the students had been instructed not to disclose their group identity to the supervising nurses or the patients in order to reduce the potential for distortion. All ratings were returned anonymously.

After completion of the six-month introductory program students were assigned to practice areas. These practice areas included pediatric wards, acute surgical and medical departments and wards, and geriatric wards. For students practicing in pediatric and geriatric wards the ethics committee did not grant approval. Patients in these wards were considered too vulnerable. Due to this reason students doing their first practice rotation in pediatrics or geriatrics were excluded from the assessment in the real clinical practice. Of the remaining 26 students ( 24 women and two men), 12 were included in the intervention group and 14 in the control group. 


\section{Instruments}

\section{Self-efficacy}

Self-efficacy is defined as the belief that one is able to successfully accomplish a given task, or, according to Bandura, Cioffi, Barr Taylor, \& Brouillard, (1988) as people's beliefs about their capabilities to produce designated levels of performance that exercise influence over events that affect their lives. The EDHEP Self-Efficacy Questionnaire consists of 12 statements: six statements concerning the students' self-perceived knowledge about the required communication skills and six statements relating to the students' degree of certainty that they were able to do what was required of them. In a previous study, the reliability of this questionnaire had been established with a Cronbach's $\alpha$ of 0.93 for the Netherlands and 0.92 for the United Kingdom (Blok et al., 2004). In our study, the two items relating to the question of organ donation were excluded because they did not apply to our scenarios (box 1). Since the questionnaire existed in English only, it was translated into German using the forward-backward method (Monti et al., 2007).

\section{Patients' perspective on the quality of communication}

The 'Art of Medicine Survey' scale (AMS) (Webster, Swanson, Ware, Carter, \& Inui, 1989 ) is an eight-item rating form for patients to rate the students' communication skills (box 2). The AMS has a response scale ranging from "not good at all" (=1) to "very good" (=6). It has been used in similar studies. Brown \& Boles, (1999) reported a Cronbach's alpha of 0.97 for the reliability of internal consistency for the eight-item questionnaire. This English-language questionnaire was also translated into German using the forward-backward method mentioned above.

\section{Supervisors' perspective on the quality of communication}

The supervisors evaluated students' communication skills using the ten-item 'Work Samples and Situation-Related Questions to Measure Workplace-Related Competences' scale [original title: “Arbeitsproben und situative Fragen zur Messung arbeitsplatzbezogener Kompetenzen", note by the author] developed by Schaper, (2003) (box 3 ). In this scale, student performance is rated on a six-point rating scale (1= "standard not met"; $6=$ "standard well met"). For interrater-reliability and internal consistency a Cohen's k=0.86 and a Cronbach's $\alpha=0.66$, respectively, have been reported for the German version. 


\section{Data analysis}

Statistical significance tests were conducted and statistical graphs were produced using SYSTAT, version 12. Because the distributions of the supervisor and patient ratings were highly skewed, the non-parametric Kolmogorov-Smirnow test was used to test for differences between the intervention and control groups, with one exception: A t-test was used for the mean over all ten items of the supervisors' ratings because it had a normal distribution. Some of the supervisors did not rate all of the items because they felt that some items of the 'Work Samples and Situation-Related Questions to Measure Workplace-Related Competencies' scale did not apply in certain situations. In these cases, only the mean of the rated items was calculated.

The distributions of students' self-efficacy ratings were approximately normal. We therefore performed an analysis of variance with control versus intervention as a between-subjects factor, and before versus after as well as "knowledge (know)" versus "practical ability (can)" as within-subjects factors. To estimate the effect size of the intervention compared to the controls, Cohen's d was computed as the difference of the two means divided by the pooled within-group standard deviation.

\section{Ethical considerations}

Ethical approval was sought from the State of Bern's ethics committee. Approval was granted to include students practicing in acute medical and surgical departments and wards. The hospital board and administrators of the places where the student rotations in acute medical and surgical departments and wards took place required that data collection was completely anonymous. Informed written consent was obtained from all participating students and supervising nurses. Patients were given an information leaflet. Participation in the study was completely voluntary. All participants could leave the study at any time without any repercussions. There was no financial compensation.

\section{RESULTS}

\section{Students' perceived self-efficacy}

No significant differences were found between control and intervention groups regarding students' perception of self-efficacy before the practice rotation and six weeks into the clinical rotation $(p=0.316$ for (know) $p=0.88$ for (can) (table 1). On the other hand, the analysis of variance showed a highly significant $(p=<0.001)$ increase in self-efficacy in both groups from before the practice rotation to the measurement six weeks into the practice rotation. Correlations between perceived knowledge (know) about the 
required skills and the perceived practical ability (can) for the required skills were high, as well before the practice rotation $r=0.75$ as six weeks into the practice rotation $r=$ 0.88 . In contrast, individual students varied in the trajectory of their self-efficacy over time resulting in low correlations for perceived knowledge (know) $r=0.12$ and perceived practical ability (can) $r=0.07$.

Table 1: Mean and p-value of self-efficacy questionnaire of the European Donor Hospital Education Program (EDHEP) to measure students' perception of self-efficacy (know and can).

\begin{tabular}{|c|c|c|c|c|}
\hline Students & & $\begin{array}{l}\text { Mean (know) } \\
\text { just before clinical } \\
\text { rotation }\end{array}$ & $\begin{array}{l}\text { Mean (know) } \\
\text { six weeks into clinical } \\
\text { rotation }\end{array}$ & p-value \\
\hline$n=29$ & control & 37.3 & 43.3 & $p=0.316$ \\
\hline$n=26$ & intervention & 39.9 & 42.4 & \\
\hline Students & & $\begin{array}{l}\text { Mean (can) } \\
\text { just before clinical } \\
\text { rotation }\end{array}$ & $\begin{array}{l}\text { Mean (can) } \\
\text { six weeks into clinical } \\
\text { rotation }\end{array}$ & $\mathrm{p}$-value \\
\hline$n=29$ & control & 35.1 & 42.1 & $p=0.88$ \\
\hline$n=26$ & intervention & 35.8 & 41.1 & \\
\hline
\end{tabular}

\section{Ratings by the patients}

A total of $n=107$ patients completed the questionnaire, 55 for the control group and 52 for the intervention group. On average, approximately 4 patients provided a rating for each individual student. The ratings were overwhelmingly positive, with a mean of 5.60 for the control group and 5.67 for the intervention group on the 6 point rating scale. The Kolmogorov-Smirnow test yielded $p=0.70$ which means that there was no statistically significant difference between the student groups.

\section{Ratings by supervising nurses}

The supervising nurses returned 94 rating forms, 48 for control students and 46 for students from the intervention group. On average, 3.5 assessments were completed per student. The Kolmogorov-Smirnow test showed that, compared to the control group, the item-level ratings of the students in the intervention group were significantly higher $(5.21(S D=0.52)$ and $4.41(S D=0.82))$ respectively. The t-test resulted in $t=5.71, p<0.0001$. The ratings of the control group were more spread out, whereas the ratings of the intervention group were clustered. 
Table 2: Mean of communication skills repeatedly assessed by various supervising nurses and patients.

\begin{tabular}{llll}
\hline Patients & & Mean & p-value \\
\hline 55 questionnaires & Control & 5.67 & $\mathrm{p}=0.70$. \\
52 questionnaires & Intervention & 5.78 & \\
\hline Supervisors & & & \\
\hline 48 questionnaires & Control & Mean & p-value \\
46 questionnaires & Intervention & 4.41 & $\mathrm{p}<0.0001$ \\
\hline
\end{tabular}

\section{Effect size}

The effect size of the difference between the nurse supervisor's individual item ratings of the two groups was calculated at Cohen's d ranged between 0.36 and 1.21. The effect sizes for the patients' assessments and the students' self-reported ratings were small (Cohen's $d$ between -0.02 and 0.46 (patients' assessments) and between -0.58 and 0.27 , respectively).

\section{DISCUSSION}

The aim of our study was to test the hypothesis that a communication skills module with SPs has superior effects compared to a module with peer role-playing. We expected that this effect would show in students' perceived self-efficacy as well as in patients' perceptions and clinical supervisors' observations of students' communication skills.

We found no significant differences between the intervention and the control group regarding students' perceived self-efficacy and ratings by the patients. However, the nurse supervisor ratings were significantly higher for the intervention group. We therefore conclude that our hypothesis is only supported by the supervisor ratings.

Students' self-efficacy ratings prior to clinical practice were high and did not differ between the intervention and the control groups. We conclude that students felt equally well prepared by the module with peer role-playing and by the module with SPs. These contrasts with findings reported by (Barrows, 1993; Dent \& Harden, 2005; Kurtz, et al., 2005) as well as with our own anecdotal experience that peer role-playing is often not taken seriously by students.

The low correlations between the first and second measurement within individuals is consistent with Eva \& Regehr, (2005) observation that factors such as success and failure can alter self-efficacy. 
When self-efficacy was reassessed six weeks later, both groups showed a significant increase in self-efficacy compared to the first measurement, which suggests that both groups had had similarly stimulating and positive learning experiences.

The consistently positive ratings by real patients may reflect an uncritical attitude of patients towards students. This assumption is supported by Feletti \& Carney (1984) who examined patient satisfaction with medical students' communication skills and found that patients were strongly inclined to give highly favorable ratings on report forms. However, informal conversations between patients and nurses revealed that patients were reluctant to criticize students even though they were quite capable of differentiating between ideal and non-ideal bedside roles. Yudkowsky, Loy, \& York, (2005) too, found that patients were poor discriminators in evaluating medical students, because of their feeling of dependence on the students' goodwill during their stay in the hospital. Another reason could be altruism and empathy towards students, as suggested by Batson, (1997) who reported that altruistic behavior is especially prevalent when the evaluator has empathy with the person to be evaluated.

In contrast to the ratings of self-efficacy by the students and the patient ratings, the ratings by the supervisors revealed significant superiority of communication skills among students in the intervention group. The supervisors observed the interaction between students and patients from an outside perspective, as professionals. McLaughlin, Gregor, Jones, \& Coderre, (2006) contend that supervisors are stricter than patients and SPs in rating student performance; this a fact can be explained by their training. Supervisors differ from SPs and patients in background knowledge and capability to distinguish between students with surface knowledge and those that have indepth understanding. Moreover they have a different role and a different relationship with students than patients in that they are responsible for the students' professional development; this may evoke the use of higher and more specific quality standards.

Our study has several limitations. To obtain evaluations of student communication skills, three different instruments, one for each participant group, were employed. There may be inherent differences in the topics measured by each instrument. Hence, comparison of the findings is limited and needs to be further explored in terms of triangulation of instruments. The different methods employed for each participant group may have skewed the actual training effect.

The intervention group had an OSCE, whereas the control group had to undergo a written exam. Hence, the intervention group had additional practice in communication than the control group. This difference may have influenced the results. In addition, the intervention group was exposed to more observation than the control group due to the OSCE. Therefore, the additional observation time may also have influenced the intervention group results.

Since the students did not have prior experience as nurses, the rotation in clinical practice, i.e. the clerkship experience during the first weeks, may have influenced the students' perception of their self-efficacy. The amount of this influence cannot be de- 
termined in this study. Further exploration of the potential confounding effect of the transition from theoretical and skills-lab training into practice needs to be explored.

Furthermore, our samples were small and, despite randomization, pre-existing differences between the two groups cannot be ruled out as we conducted no pre-test. In addition, the study was conducted in one nursing school with two sites.

Two of the instruments employed in this study to evaluate students' communication skills in real practice needed to be translated from English into German. In addition, two items relating to the question of organ donation were excluded because they did not apply to our scenarios. All these changes may have influenced the reliability of the instrument. Further exploration of the difference between communication skills training involving standardized patients as opposed to peer role-play needs to be conducted.

Our study is one of the few to investigate the influence of SPs in a CST in combination with OSCE in training and assessment of communication skills modules in the clinical practice of nursing education. Despite the limitations of our study, the results suggest that training and assessment with SPs in CST modules involving OSCEs leads to greater improvement of communication skills when assessed by professional supervisors. This finding is an important argument to justify investments (financial and in terms of human resources) in communication training modules with SPs. The results also indicate that the instruments we used may be problematic for patient and student assessments of the effect of communication skills training.

To verify our conclusions, studies with larger samples need to be conducted. Such studies should use the same assessment formats for all groups to prevent an influence of the format on the results. We recommend that the effects of communication skills modules be assessed in the clinical setting by supervisors rather than by students or patients. The potential superiority of communication training with SPs could be confirmed in a study using incognito SPs to assess students' communication skills, a method described by Gorter et al., (2002) who suggest that the incognito SP method should be applied in studies aimed at obtaining very specific information on students' clinical performance.

In summary, the results of our study provide evidence that, in communication training, using SPs is superior to peer role-playing. Moreover, in contrast to clinical supervisors, patients do not seem to discriminate students' communication skills adequately, and the measurement of students' perceived self-efficacy does not contribute to the detection of differences between the two methods of communication skills training. 


\section{LITERATURE}

Amin Z., Chong Y. S., \& E., K. H. (2006). Practical Guide to Medical Student Assessment. New Jersey: World Scientfic.

Bandura, A., Cioffi, D., Barr Taylor, C., \& Brouillard, M. E. (1988). Perceived self-efficacy in coping with cognitive stressors and opioid activation Journal of Personality and social Psychology (Vol. 55, pp. 479488).

Barrows, H. S. (1993). An overview of the uses of standardized patients for teaching and evaluating clinical skills Academic Medicine (Vol. 68, pp. 443-453).

Batson, C. D. (1997). Self-other merging and the empathy-altruism hypothesis: Reply to Neuberg et al. Journal of Personality and social Psychology (pp. 517-522).

Becker KL, Rose LE, Berg JB, Park H, \& JH., S. (2006). The teaching effectiveness of standardized patients. Journal of Nursing Education, 45(4), 103-111.

Blok, G. A., Morton, J., Morley, M., Kerckhoffs, C. C., Kootstra, G., \& van der Vleuten, C. P. (2004). Requesting organ donation: the case of self-efficacy--effects of the European Donor Hospital Education Programme (EDHEP). [Research Support, Non-U.S. Gov't]. Advances in health sciences education : theory and practice, 9(4), 261-282. doi: 10.1007/s10459-004-9404-6

Blok, G. A., Morton, J., Morley, M., Kerckhoffs, C. C. J. M. C., Kootstra, G., \& Van der Vleuten, C. P. M. (2004). Requesting organ donation: The case of self-efficacy. Advances in Health Scinces Education, 9, 261-282.

Bokken, L., Linssen, T., Scherpbier, A., van der Vleuten, C. P. M., \& Rethans, J. (2009). Feedack by simulated patients in undergraduate medical education: a systemic review of the literature. Medical Education, 43(1), 202-210.

Bosse, H. M., Nickel, M., Huwendiek, S., Junger, J., Schultz, J. H., \& Nikendei, C. (2010). Peer role-play and standardised patients in communication training: a comparative study on the student perspective on acceptability, realism, and perceived effect. [Randomized Controlled Trial]. BMC Medical Education, 10, 27. doi: 10.1186/1472-6920-10-27

Brown JB, \& Boles M, M. J., Levinson W. (1999). Effect of clinician communication skills training on patient satisfaction. A randomized, controlled trial. Ann Intern Med. , Dec.7(131(11)), 822-829.

Browning, D. M., Meyer, E. C., Truog, R. D., \& Solomon, M. Z. (2007). Difficult conversations in health care: cultivating relational learning to address the hidden curriculum. Academic medicine : journal of the Association of American Medical Colleges, 82(9), 905-913. doi: 10.1097/ACM.0b013e31812f77b9

Dent, J. A., \& Harden, R. M. (Eds.). (2005). A practical guide for medical teachers: Elsevier.

Epstein, R. M., Franks, P., Shields, C. G., Meldrum, S. C., Miller, K. N., Campbell, T. L., \& Fiscella, K. (2005). Patient-centered communication and diagnostic testing. [Research Support, U.S. Gov't, P.H.S.]. Annals of family medicine, 3(5), 415-421. doi: 10.1370/afm.348.

Eva, K., \& Regehr, G. (2005). Self-Assessment in Health Professions: A Reformulation and Research Agenda. Academic Medicine, 80(10), 546-554.

Feletti, G. I., \& Carney, S. L. (1984). Evaluating patients' satisfaction with medical students' interviewing skills Medical Education (1984/01/01 ed., Vol. 18, pp. 15-20).

Gorter, S., Rethans, J., Van der Heijde, D., Scherpbier, A., Houben, H., Van der Vleuten, C. P. M., \& Van der Linden, S. (2002). Reproducibility of clinical performance assessment in practice using incognito standardized patients. Medical Education, 36, 827-832.

Kurtz, S., Silverman, J., \& Draper, J. (Eds.). (2005). Teaching and learning communication skills in medicine (2nd ed.): Radcliff Medical Press.

Lane C., \& Rollnick S. (2005). The use of simulated patients and role-play in communication skills training: A review of the literature to August 2005. Patient Education and Counseling, 67, 13-20.

May, W., Park, J., H., \& Lee, J., P. (2009). A ten-year review of the literature on the use of standardized patients in teaching and learning:1996-2005. Medical Teacher, 31, 487-492.

McLaughlin, K., Gregor, L., Jones, A., \& Coderre, S. (2006). Can standardized patients replace physicians as OSCE examiners? BMC Medical Education, 6(12), 1-5. 
Monti, F., Lupi, F., Gobbi, F., Agostini, F., Miano, A., Gee, L., \& Abbott, J. (2007). Validation of the Italian version of the cystic fibrosis quality of life questionnaire (CFQoL), a disease specific measure for adults and adolescents with cystic fibrosis. Journal of Cystic Fibrosis, In press.

Moon S., \& Y., Y. (2003). The effectiveness of standardized patients as a teaching method for nursing fundamentals. Journal of nursing education, 42(10), 431-432.

Nestel, D., \& Tierney T. (2007). Role-play for medical students learning about communication: Guidelines for maximising benefits. BMC Medical Education, 7(3), 1-9.

Schaper, N. (2003). Arbeitsproben und situative Fragen zur Messung arbeitsplatzbezogener Kompetenzen. In J. Erpenbeck \& L. von Rosenstiel (Eds.), Handbuch Kompetenzmessung (pp. 185-199). Stuttgart: Schäffer-Poeschel.

Simpson, M., Buckman, R., Stewart, M., Maguire, P., Lipkin, M., Novack, D., \& Till, J. (1991). Doctor-patient communication: the Toronto consensus statemen. BMJ, 303(November), 1385-1387.

Snadden, D., \& Ker, J. S. (2005). Communication skills. In J. A. Dent \& R. Harden (Eds.), A practical guide for medical teachers (second edition ed., pp. 238-247). Edinburgh: Elsevier.

Stewart, M. (2001). Towards a global definition of patient centred care. BMJ British Medical Journal, 322, 444-445.

Wallace, P. (2007). Coaching standardized patients for use in assessment of clinical competence. New York: Springer Publishing Company.

Webster, D., Swanson, D., Ware, J. E., Carter, W., \& Inui, T. (1989). Final Report on the Patient Satisfaction Questionaire Project. American Board of Internal Medicine.

Yudkowsky, R., Loy, G., \& York, J. (2005). Ensuring medical student competency in basic procedural skills. Medical Education, 39(5), 515-516. doi: 10.1111/j.1365-2929.2005.02160.x 



\section{CHAPTER 5}

Standardized Patients' perspectives on workplace-satisfaction and work-related relationships: A multi-centre study

Schlegel Claudia

Bonvin Raphael

Rethans Jan-Joost

Van der Vleuten Cees P.M.

Accepted for publication in Simulation in Health Care 


\section{ABSTRACT}

\section{Introduction}

The use of Standardized Patients (SP) in healthcare education has grown in the last fifty years. In addition, the requirements for SPs have increased steadily and thus the work of SPs has become more difficult and demanding. It has been claimed that SP programmes are highly contextualised, having emerged from local, institutional, professional and national conditions but their effects on SPs have not been investigated. We have studied the effects of this job development on SPs and their programmes.

\section{Method}

The study was conducted using a qualitative research design, with semi-structured Individual In-Depth Interviews (IDIs) to understand the reactions, values, and perceptions that underlie and influence SP behaviour. To cover SP perspectives from more than one SP programme, a total of 15 SPs from eight different nursing schools and medical schools in Switzerland were asked to participate.

\section{Results}

SPs feel motivated, engaged and willing to invest effort in their task and do not mind demands increasing as long as the social environment in SP programmes is supportive. The role of the SP trainer and the use of feedback is considered very important.

\section{Conclusion}

SP programmes require concepts in which the SP perspective has been integrated to better serve SPs' well-being. SPs are valuable partners in the training of health professionals - we need to take care of them. 


\section{INTRODUCTION:}

Fifty years ago Barrows described the need for a new patient-oriented method for testing medical students in the domain of clinical skills (1). This was because real patients in student examinations always introduced variation into the assessment, making students' competencies difficult to compare. The "programmed patient" was thus devised to provide a more standardized test for students. The new method involved the standardized simulation of a neurological disease by a healthy person trained to present the history and behaviour of an actual patient. Later, the method was renamed 'the simulated patient method' and its use was no longer restricted to neurological diseases (2-4).

Since its start the SP method has developed considerably. While, the original emphasis was on portraying a patient only, in the early 1970s, SPs' feedback after a student encounter also became important: students were given feedback on their interviewing skills (2). In the 1980s, the use of SPs in assessment became common, e.g. in the Objective Structured Clinical Examination (OSCE). The term "standardized patient" instead of simulated patient became a generally accepted term for SPs (5), at least in the United States.

Over the years, the requirements for SPs have become more difficult and demanding. Now there are SP trainers who are responsible for supervising and supporting them in manifold competencies, (6) e.g. in portraying a patient according to a standardized role-script, in observing students' behavior, in recalling the encounter for a feedback checklist and in giving feedback on the student's diagnostic questioning (7). The quality of SP role-play and feedback has become more important and appropriate evaluative instruments have been developed (8-10).

The use of SPs in assessment and teaching in medical education has grown worldwide (11), as have SP training programmes. Increasing SP professionalism, in turn, raises questions as to what effects stricter requirements and higher numbers of SPS per SP programme have on the SPs in the programmes involved. In a more demanding working world, a further question is how much SPs are committed to doing their current work. Work satisfaction and an appropriate workplace relationship are determinants of organizational commitment (13), and employees with high work satisfaction are willing to acccept high demands when necessary (14). Sempane, Rieger and Roodt (15) describe work satisfaction as people's assessment of their job in terms of the issues and concerns that matter; the feelings and emotions involved in work will have considerable influence on a person's work attitude. Unfortunately, there is a lack of specific research analysing SPs' work satisfaction and workplace relationships, although research focused on work satisfaction and relationships in general is very common. Findings indicate that the social factors of work, i.e. interaction, friendships, and emotional support are even more important than autonomy task variety, and the significance of work (16). Other studies show that social factors and the surrounding 
environment play an important role in work satisfaction (17). Chang (13) concluded, after investigating a sample of 400 nurses, that good relationships lead to a sense of belonging and help to improve nurses' job satisfaction.

A correlation between motivation and work satisfaction has also been suggested. Altruistic motivations like wanting to improve health care personnel interactions with patients or wanting to help in health professional education, as well as more mundane motivations like financial rewards or new acting opportunities, can lead people to become an SP (19). However, Luthans (20) argues that personal motivation should not be seen as the only justification for individual work behaviours, which are also derived from the surrounding social environment. Even though SPs are generally employed part-time or hired by the hour, the need for social relationships at work does not change (21).

Positive work satisfaction linked with good work relationships (16) leads to positive work engagement. Schaufeli, Bakker, and van Rehnen, (22) state that work engagement is a positive, affective-motivational state of fulfilment that is characterized by vigour (a willingness to invest effort in a job), dedication (a strong involvement in work), and absorption (characterized by time passing quickly). Engaged workers, be they full-time, part-time or hourly, work better because they are intrinsically motivated, prepared to face new challenges, show pro-social behaviour, process gathered facts better, (22) and are recognized by their high quality performance and high retention rate $(23,24)$. High quality performance and high retention rate are welcome in the training of medical professionals for both patient safety and budget reasons.

The purpose of this research is to investigate SPs' current perspectives on workplace satisfaction, work-related relationships, and engagement in light of the current demands placed on SPs, focusing on the key elements of today's state-of-the-art requirements $(7,12,25)$ for being an SP. Knowing and understanding this perspective is not only important for SP trainers, but also for SP coordinators, as they are responsible for recruitment policy, SP welfare and hospitality (6). With this knowledge and understanding, SPs should get enough support to devote effort to achieving the SP programme's objectives and remain with the organization.

\section{METHOD}

The study was conducted using a qualitative research design to understand the reactions, values, and perceptions that underlie and influence SP behaviour. Qualitative research focuses on answering "why and how" and explores "real life" behaviour, enabling research participants to speak for themselves (26). This leads to a broader understanding of the SP view, providing insight and information for practical implementation(29). To illuminate the research question of what makes SPs engaged, the methodological approach of Grounded Theory was used to provide a detailed, rigorous, and systematic method for data collection and analysis. 
As workplace satisfaction and workplace relationships are very personal topics, semi-structured Individual In-Depth Interviews (IDIs) (30) were conducted, allowing participants to feel comfortable and talk openly. Another advantage is that IDIs can be conducted in various places (31), including via the Internet (32), and can be more convenient and less threatening to interviewees.

\section{Subjects}

To cover SP perspectives from more than one SP programme, a total of 15 SPs from eight different nursing - and medical schools in Switzerland were asked to participate. This was arranged purposely, as SPs in different programmes may have divergent work-related norms, practices, and expectations (33). The participating schools are different locations and curricula, and are autonomous. Each school has its own SP programme, SP coordinator, and SP trainers. All schools conduct OSCEs and also have formative SP-Student encounters, where SPs give oral feedback to students after the encounter. As any patterns emerging from the IDIs need to be confirmed or refuted by subsequent interview data, a purposeful sampling approach (28) was chosen, using SPs who were knowledgeable and experienced and had the ability to communicate experiences and opinions in an articulate, expressive, and reflective manner. Initially 10 SPs, six females and four males aged 24-72 years with over one year of SP experience participated. Four were certified actors and six were lay-people. Two were employed fulltime by their school; the others, by the hour. Through constant comparative analysis of data gained, theoretical sampling was used for a better understanding of the pattern that was evolving. Based on the need to collect more data to examine categories and their relationships, we conducted five more IDIs with SPs from the French-speaking part of Switzerland, three female and two male.

\section{Topic guide for semi-structured IDIs}

The topic guide (Table 1) shows the key elements of SP practice as well as elements of the Utrecht Work Engagement Scale (UWES) (22), a validated instrument which showed good internal consistency and test-retest reliability, and the Andrews and Withey Job Satisfaction Scale, which was construct and concurrent validated (34). Both instruments served as guidance for the semi-structured IDIs with the SPs. We chose these instruments as their content best matched the purpose of this study. The topic guide was open-ended and therefore allowed respondents enough scope to talk about their opinions on a particular subject. The topic guide was piloted first, but few modifications were necessary after piloting. An experienced moderator led the face-to-face, semi-structured IDIs, each one hour, in the presence of an observer. It was important that moderator and observer were independent. The topic guide encouraged discus- 


\section{CHAPTER 5}

sion of SPs' experience in the many elements of their practice. The semi-structured IDIs were audio recorded and transcribed by an external assistant.

Table 1: Topic guide for the semi- structured Individual In-Depth Interviews inspired by elements of the Utrecht Work Engagement Scale (UWES) and Andrews and Withey Job Satisfaction Scale Being an SP

\begin{tabular}{lll}
\hline Main question & Additional question & Clarifying question \\
\hline How do you feel about being an SP? & Dealing with the state-of-the-art & Can you expand on this? \\
& requirements? & Can you tell me anything else? \\
& Do the increasing demands for SPs & Can you give me some examples? \\
& affect you? \\
What inspires you in being or & What was/were your main \\
wanting to remain an SP? & reason(s) for wanting to be an SP? \\
& To what extent has/have this/these \\
& reason(s) for being an SP changed \\
& since you started \\
& What specifically has changed and \\
& why?
\end{tabular}

Workplace engagement

\begin{tabular}{|c|c|c|}
\hline Main question & Additional question & Clarifying question \\
\hline & With regard to: & \\
\hline What do you need from the & Willing to invest effort in being an & Can you expand on this? \\
\hline institution to feel engaged while & $S P ?$ & Can you give me some examples \\
\hline \multirow[t]{2}{*}{ working as an SP? } & Not easily fatigue? & Try to explain why you feel this or \\
\hline & $\begin{array}{l}\text { Persistence in the face of } \\
\text { difficulties? }\end{array}$ & what makes you feel like this? \\
\hline
\end{tabular}

Workplace satisfaction

\begin{tabular}{|c|c|c|}
\hline Main question & Additional question & Clarifying question \\
\hline & With regard to: & \\
\hline \multirow[t]{4}{*}{$\begin{array}{l}\text { To what extent are you satisfied with } \\
\text { the working environment where you } \\
\text { are active as an SP? }\end{array}$} & $\begin{array}{l}\text { Surroundings, that is the } \\
\text { building(s), the rooms, entrance, } \\
\text { etc.? }\end{array}$ & $\begin{array}{l}\text { Do the surroundings (buildings, } \\
\text { rooms, entrance, etc.) affect your } \\
\text { performance as an SP? }\end{array}$ \\
\hline & $\begin{array}{l}\text { The amount of SP-work you were } \\
\text { asked to do in the last year? }\end{array}$ & \\
\hline & Hours of work during an OSCE? & $\begin{array}{l}\text { Do you think you work too many } \\
\text { hours during an OSCE day? }\end{array}$ \\
\hline & With regard to: & \\
\hline To what extent do other aspects, & Equipment? & \\
\hline apart from those already covered, & Information? & \\
\hline influence you in being satisfied as an & Supervision? & \\
\hline \multirow[t]{3}{*}{$S P ?$} & Feedback? & \\
\hline & Gratitude? & \\
\hline & Payment? & \\
\hline
\end{tabular}


Workplace relationship

\begin{tabular}{lll}
\hline Main question & Additional question & Clarifying question \\
& With regard to: & \\
How is your performance as an SP & Co-workers (SPS)? & Can you expand on this? \\
influenced by the people you & SP-trainers? & Can you give me some examples? \\
collaborate with? & Administration? & \\
& Students? & \\
& Staff?
\end{tabular}

Are there any other things you would like elaborate on that you have told me so far?

Are there any other things you would like add that I didn't ask about yet?

\section{Iterative process}

The transcripts were then read line-by-line by two researchers and constantly compared while the data were collected. This was important in order to become familiar with the ideas, patterns and stories of early participants. This allowed early analytical insights and conceptual ideas to shape the subsequent data collection. Findings that were unanticipated or that might represent a compelling area for further exploration were followed up in the subsequent interviews, as recommended by Watling (29).

\section{Coding}

The transcripts of all 15 interviews were read line by line, to elicit "what's happening here". Data were compared with data, statements with statements, story with story and incident with incident. Notes on ideas were made as they emerged from the data. The constant reading and comparing of the transcripts resulted in the establishment of initial codes or categories. A definition of what to include and what to exclude in the code/category was formulated and initial code definitions were defined. A second researcher independently confirmed the initial codes.

In a second cycle the initial codes were reorganized and re-analysed. Axial coding extended the analytic work from initial coding, determining which codes were dominant and which less important, and the data was reorganized accordingly (35). Similarly, coded data was sorted and relabelled into conceptual categories. No qualitative software was used in the coding process due to the small sample size of 15 IDIs; however, two researchers independently confirmed the coding.

\section{ETHICAL APPROVAL}

According to the Swiss ethics committees on research involving humans, research studies reporting perceptions of employees do not require approval. Through informed consent, the study participants were made aware that the participation was 
voluntary, that they could freely choose to stop participation at any point in the study and that their participation had no effect on their employment. The participants were assured that the interview transcriptions and the statements were anonymous.

\section{RESULTS}

The analyzed data encompassed statements collected from 15 interviews. The results are presented according to the themes in the topic guide for the semi- structured interviews.

\section{Being an SP}

Altruistic reasons were the motivation most often cited for being an SP. The general opinion was that being an SP is an important job because it contributes so much to student outcomes, healthcare, and society. SPs are confident that students can benefit from their work. They feel needed and think they are important in students' clinical training. Some SPs have had negative personal experiences themselves with doctors and nurses, especially with respect to doctor-patient communication; by being SPs, they hope to contribute to better patient-nurse/doctor communication.

"Students can take something with them on their way to becoming (medical) professionals from my efforts as an SP. That's one of the most important things and gives me a good feeling."

"One of my main motivations is that they get on with their patients as well as possible, that they and their patients feel comfortable." (IDI 3)

Another SP motivator is learning about illnesses and diseases, which helps SPs in their own future medical consultations. Apart from this, being an SP is challenging, because encounters with students are not predictable. On the other hand, working with students who cannot cope with the method or do not take the learning opportunity seriously is difficult for SPs. They try to motivate students to take advantage of the opportunity provided by simulation, and cannot understand that some students reject it.

SPs believe that their work is important for the professional development of health care students.

"There are some students who have trouble with this method. It's hard for me then.

So I tell them that they can only benefit from these settings and sometimes that helps." (IDI 2)

Therefore, in some cases, SPs believe they did not perform well, especially when students do not react as predictably as desired. In such situations feedback from the SP 
trainer plays a key role in clarifying possible misunderstandings and providing an immediate and objective response to how the performance was perceived by students.

"For me it is important to get feedback from the SP trainer in such situations, because I'm uncertain then myself." (IDI 5)

Feedback and performance feedback from the SP trainer is expected both during the role-play- and feedback-training and after the encounter to allow the SPs to reflect on their own performance and gain security and motivation for future tasks.

"Sometimes I don't get any feedback on my performance. That's hard for me, because then I'm not sure if I did everything correctly." (IDI 10)

For role-play training, the SPs expect the SP trainer to provide information about the illness they have to portray. Most of the SPs assume that the more information they have about the signs and symptoms they need to simulate, the better they can understand and identify with their role.

"I had to play a patient with a stoma. Since I received no information from the SPtrainer about why a person has to have a stoma, I found it completely weird to imagine that someone had to have it. It affected me strongly and I couldn't get into the role." (IDI 4)

\section{Workplace engagement}

Information, feedback, and a sense of security appear to be motivators in workplace engagement. If these elements are correctly addressed and present throughout their work, SPs look forward to new inputs and challenges. The essential information needed comprises symptoms and other characteristics of the disease or illness they have to portray, students' level of training, faculty they are cooperating with and educational goals of the training. SPs are strongly involved in their work if they know the context in which they are performing.

SPs appreciate working with the same SP trainer over a longer time, so that they get to know each other, which is perceived as a situation of low anxiety, security and trust.

"I have known the SP trainer for a long time and am always glad to attend her training sessions. With every session I learn something new, and she helps me if I don't understand the role or have problems with the feedback training." (IDI 8)

"I am really looking forward to my next assignment because the SP trainer trains in a very appreciative way and mistakes are allowed." (IDI 1) 
A trusting, appreciative workplace relationship and environment, with an emphasis on feedback and security, help the SP not only to handle growing requirements, but motivates them to invest effort in being an SP.

\section{Workplace relationship}

SPs like to be treated with respect. They like to be called by their names and greeted by faculty and SP trainers. In some places SPs receive special catering during their deployment, which is very much appreciated. A satisfying workplace relationship leads to involvement and commitment, accompanied by feelings of enthusiasm and significance. Longer hours and rising requirements do not affect SPS as long as they experience gratitude. Appreciation seems to be more important than pay. However, professional actors think they should earn more than lay-persons. Some lay-persons do not feel comfortable being trained with professional actors, because it triggers feeling of inadequacy. In this case a respectful and team-oriented attitude from the SP trainer is appreciated by the SPs, so all can concentrate on the training and feel satisfied.

A workplace relationship based on trust and confidence offers autonomy and responsibility. SPs like to have autonomy and some of them have good selfmanagement. They have strategies for identifying with the role they have to play and develop their own debriefing concepts. Besides autonomy, more experienced SPs like to take responsibility for the progress of their own learning. Having autonomy and responsibility motivates the SPs to invest effort in their job and the persistence to face difficulties.

\section{Workplace satisfaction}

SPs in general like assignments that take several hours, because some SPs come from far away and the expense (time and money) of traveling should be worthwhile. They like to have their work scheduled as early as possible, so they can plan the rest of their time. If they are not scheduled for a subsequent assignment, they feel insecure, because they do not know why they were overlooked.

"I did not know why I was left out. Perhaps I am too old or I did not do my last assignment well enough.... when I called the SP trainer none of these reasons were confirmed; it made me feel safe." (IDI 9)

The work-place environment does not have to be state-of-the-art, but it has to be clean and warm.

"When I put my head on the pillow it smelled. I could not concentrate on my task because the pillow smelled, even though it was a clean pillowcase...." (IDI 5) 
"During an OSCE most students forgot to cover me up with a blanket after their examination. I was freezing because the room was not heated enough, this was very unpleasant." (IDI 4)

A trustful working climate helps SPs to openly and transparently communicate about issues that disturb them during their performance. The prerequisite is that the SP trainer and coordinator are prepared to listen and take SPs' concerns seriously to create a trustful working climate, increasing SPs' motivation, engagement and satisfaction.

\section{DISCUSSION}

The purpose of this research was to investigate SPs' perspectives on workplace satisfaction, work-related relationships, and engagement in the light of current demands on SPs. Our analysis provided insight into SPs' apprehension of being an SP and how they perceive their associated assignments. Based on the IDI statements, SPs in general were satisfied with their workplace and work relationships. SPs felt motivated, engaged, and willing to invest effort in their task and did not mind increasing demands as long as the social environment was supportive. This finding leads us to the previously mentioned concept of Work Engagement (22), which is a positive, motivational state of work-related well-being characterized by vigour, dedication, and absorption(22). These motivational performance indicators are described as intrinsic rather than extrinsic work motivations, i.e., motivations from inside an individual rather than from external or outside rewards. (22). Intrinsic and extrinsic motives may coexist and need not be antagonistic (36). In the concept of work engagement, intrinsic motivation is of major importance, as its presence facilitates higher work satisfaction, engagement and performance (37). This also corresponds with Herzberg's Two Factor Theory (38), based on the assumption that there are two sets of factors that influence motivation in the workplace: hygiene factors which are extrinsic and linked to compensation, working conditions, etc., and motivators, which are linked to the intrinsic motivation of the job itself, including recognition, achievement and opportunities for growth.

This investigation shows that SPs have a strong desire for recognition for performing successfully, ideally through feedback from the people they work for. Feedback enables individuals to develop intrinsic motivation and interest and is assumed to support feelings of competence (39). In addition, further attributes of feedback are concentrated on error correction and achievement change, and have motivational effects (39). Instruments (8-10) exist which enable high quality feedback to the SP. Therefore, to promote SP development, institutionalizing SP performance feedback in SP programmes is recommended, thereby increasing both quality and the opportunity to 
learn and develop. SPs can also take responsibility for their own development process by writing their own SP portfolio.

As the results showed, SPs are motivated to cope with demanding tasks provided that the SP trainer supports them in an encouraging way. Positive interventions can increase positive emotions and engagement, which enable SPs to advance to a higher level of performance. However, these increases are temporary rather than permanent (22). To keep SPs challenged and engaged, some SP programmes offer advanced training, such as bringing more theoretical communication models into their training.

Even for highly motivated SPs, trainers should remember that the often highly emotional nature of simulated patients' roles can affect SPs. Several authors (40-42) report that although symptoms such as stress, exhaustion, and dissatisfaction are reported by SPs, they are moderate and short-lived (41). It is suggested that great care be taken in the selection of SPs and that monitoring and debriefing is essential. Experienced SPs have their own strategies for leaving the character they were playing by taking a shower, dancing, or just opening the window and breathing fresh air. Regardless of those strategies, the SP trainer should be present and have an open and trustworthy manner so SPs are able to get advice or help if needed.

Information is what SPs appreciate and desire. Information about the patient case and the illnesses and diseases they have to simulate helps SPs to become involved in their work. The knowledge gained has further consequences, as SPs believe their medical knowledge is improved, which leads to a change in the way they deal with their own symptoms (43). This impact makes SPs feel competent and appreciated, thus promoting more self-confidence and awareness (43).

Altruistic reasons are another intrinsic motivator for SPs. 'Altruistic' describes someone who is concerned for the welfare of another, without any ulterior motive (44). SPs would like to help students to become good communicators and health professionals, and thus to contribute to healthcare and society. But there are also hidden motives for becoming an SP, such as negative experiences with the healthcare system or a personal crusade concerning the health professions (6). In this case, instead of altruistic reasons, the literature mentions psychological egoism (44), which could also be a motivator for being an SP. Psychological egoism refers to the thesis that we are always deep down motivated by what we perceive to be in our own self-interest; in other words there is an ulterior motive when we help others, one that tends to fly below the radar of consciousness (44).

Regardless of the motivation, the recruiting and selection of SPs must be done with great care (45). Enrolling SPs with a hidden agenda, e.g. those who cannot cope with their own illness or have a negative attitude towards the medical profession, into a medical school database might lead to situations that could be damaging to students (6) or the SPs themselves. Good supervision and interpersonal skills on the part of the SP coordinator or SP trainer are essential in such cases in order to find a satisfactory solution for both parties. 
Working hours were also a topic SPs addressed during the IDIs. Some SPs who travel a considerable distance to work and are not compensated for their travel expenses would like to have an assignment which takes more than just a couple of hours. It is recommended that SPs should not portray a given patient role for more than seven student encounters a day, including a 30 minute break after a few encounters, to reduce SPs' load (41).

Extrinsic motivation such as work-relationship, security, salary, and work environment are important and support people's work satisfaction when in place (16), but once extrinsic motivators are satisfied the effect soon wears off, as this type of satisfaction is only temporary. Therefore it is important that institutions understand that people are not 'motivated' by merely addressing those needs.

This investigation shows that the behaviours of SP trainer and SP coordinators are crucial for the well-being of the SPs. They should be familiar with concepts such as Work Engagement (22), the Two-Factor Theory of motivation (38), and have expertise in the domain of engaging and working with SPs. Training and programme staff should also be knowledgeable regarding the needs of SPs, possess interpersonal skills, and have experience in development and advancement of SP education and research in the health sciences. Based on the results of this study and the concepts mentioned above we designed a non-static and context-adaptable SP oriented working spread-sheet (SOWSS, Table 2). This is meant to support SP trainers and SP coordinators in planning and organizing training events from an SP-centric point of view. It constitutes a good basis for setting up and maintaining SP programmes and conducting SP training sessions. 
Table 2: Example of a SP-Oriented Working Spread-Sheet (SOWSS), to support SP trainers and SP coordinators in planning and organizing training events from an SP-centric point of view.

\begin{tabular}{|c|c|c|c|c|c|}
\hline \multirow[t]{3}{*}{ Items } & \multirow[t]{3}{*}{ Tasks for trainer and /or coordinator } & \multicolumn{2}{|c|}{ Responsibility } & \multicolumn{2}{|c|}{ Motivation } \\
\hline & & \multirow{2}{*}{$\begin{array}{l}\text { SP } \\
\text { Trainer }\end{array}$} & $\mathrm{SP}$ & Intrinsic & Extrinsic \\
\hline & & & \multicolumn{3}{|c|}{ Coordinator } \\
\hline Appreciation & $\begin{array}{l}\text { Create an appreciative atmosphere. Greet your SPs by } \\
\text { name and treat them with a smile and some humor. } \\
\text { Recognize SPs' performance in individual discussions } \\
\text { or in groups. Be present and listen to the SPs needs. }\end{array}$ & 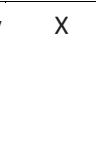 & $x$ & $x$ & \\
\hline Feedback & $\begin{array}{l}\text { Institutionalize structured SP feedback after every } \\
\text { performance. Use validated instruments and case- } \\
\text { specific checklists. If you videotaped the performance, } \\
\text { let the SP see the performance and give them the } \\
\text { chance for self-reflection. Some instruments allow the } \\
\text { feedback of other stakeholders such as students and } \\
\text { other SPs. Discuss the different perceptions of the SP } \\
\text { performance. Let the SP protocol the most important } \\
\text { inputs. Ask the SP to write down the new findings into } \\
\text { their own SP portfolio. } \\
\text { Evaluate the next performance based on the last } \\
\text { protocol. }\end{array}$ & (1) & & $x$ & \\
\hline $\begin{array}{l}\text { Opportunities } \\
\text { to learn and } \\
\text { develop }\end{array}$ & $\begin{array}{l}\text { sCreate different level programs so that SPs are } \\
\text { challenged and encouraged to learn and develop. } \\
\text { Discuss the further steps of development with the SP. } \\
\text { Write down a development plan for every SP. }\end{array}$ & $x$ & $x$ & $x$ & \\
\hline $\begin{array}{l}\text { Job } \\
\text { autonomy }\end{array}$ & $\begin{array}{l}\text { SPs have their own concepts and coping strategies, } \\
\text { e.g. how to debrief. Discuss them with the SPs and do } \\
\text { not impose your own concepts upon the SP. } \\
\text { Give SPs the space they need and create a trustful } \\
\text { atmosphere. }\end{array}$ & $x$ & $x$ & $x$ & \\
\hline Responsibility & $\begin{array}{l}\text { SPs should take responsibility for their own learning } \\
\text { whilst SPs write their own portfolio } \\
\text { Listen to SPs' ideas and inputs take them serious and } \\
\text { enter into a dialogue with the SP }\end{array}$ & $x$ & & $x$ & \\
\hline Job security & $\begin{array}{l}\text { Inform SPs as soon as possible how many assignments } \\
\text { per year are planned for each of them. Be transparent } \\
\text { and honest about why an SP is not employed for the } \\
\text { next assignment. } \\
\text { Talk to the SP if s/he does not show the performance } \\
\text { expected. Choose the level of SP-training programme } \\
\text { which fits the SP. }\end{array}$ & & $x$ & & $\mathrm{x}$ \\
\hline Salary & $\begin{array}{l}\text { Be transparent about salary. } \\
\text { Pay the salary within the normal period and if possible } \\
\text { include benefits such as health insurance, pension } \\
\text { provision, etc. in the salary. } \\
\text { Adapt the salary to local conditions. }\end{array}$ & & $x$ & & $x$ \\
\hline
\end{tabular}




\begin{tabular}{|c|c|c|c|c|}
\hline \multirow[t]{2}{*}{ Items } & \multirow[t]{2}{*}{ Tasks for trainer and /or coordinator } & \multicolumn{2}{|c|}{ Responsibility } & \multirow{2}{*}{$\frac{\text { Motivation }}{\text { Intrinsic Extrinsic }}$} \\
\hline & & $\begin{array}{l}\text { SP } \\
\text { Trainer }\end{array}$ & $\begin{array}{l}\text { SP } \\
\text { Coordinator }\end{array}$ & \\
\hline $\begin{array}{l}\text { Work } \\
\text { environment }\end{array}$ & $\begin{array}{l}\text { Check the rooms. Are the rooms warm, are they } \\
\text { clean, do the beds have new sheets? Is the material } \\
\text { complete? } \\
\text { Do SPs get catering services? } \\
\text { Is there is a shower for SPs and/ or a room where they } \\
\text { have privacy and can relax? }\end{array}$ & $x$ & $x$ & $x$ \\
\hline Supervision & $\begin{array}{l}\text { Do SP trainers have competences such as } \\
\text { interpersonal competence, knowledge, and expertise } \\
\text { in the domain of SPs? } \\
\text { If not, try to educate SP trainers so that they are } \\
\text { valuable for the SPs, the programme, and institution. }\end{array}$ & & $x$ & $x$ \\
\hline $\begin{array}{l}\text { Working } \\
\text { conditions }\end{array}$ & $\begin{array}{l}\text { Try to schedule the SPs early enough so that they are } \\
\text { free to plan other assignments. } \\
\text { Make sure SPs have a maximum number of } 7 \\
\text { encounters a day with scheduled breaks between } \\
\text { each encounter. } \\
\text { Do not schedule too tightly. Give SPs the opportunity } \\
\text { to communicate socially and foster relationships with } \\
\text { other SPs. }\end{array}$ & & $x$ & $x$ \\
\hline
\end{tabular}

Note: The SOWSS Spread-Sheet is derived from the findings of the 15 SP IDIs and the concept of Work Engagement and the Two Factor Theory. It is non-static and context-adaptable.

This investigation aimed to access the personal perceptions and motivations of SPs and is restricted by the following limitations. First, the research was conducted in Switzerland. Although cultural differences were addressed by investigating SPs from different institutions and parts of Switzerland (German- and French-speaking), the perceptions of the SPs interviewed may not be an accurate representation of the whole profession.

The question also arises whether a sample size of 15 SPs was sufficient or if a bigger sample would have resulted in different findings. Further studies should be conducted in various institutions and countries to determine if different cultures have different motivators for workplace satisfaction, work engagement, and work relationships.

SPs manage their tasks and current requirements well when certain intrinsic and extrinsic motivators are considered. Therefore, SP programmes and their management require concepts in which SPs' perspectives, particularly their motivations, have been considered. 


\section{LITERATURE}

1. Barrows HS, Abrahamson S. The Programmed Patient: A Technique for Appraising Student Performance in Clinical Neurology. Journal of Medical Education. 1964 Aug;39:802-5.

2. Stillman PL, Brown R, Redfield DL, Sabers DL. Construct validation of the arizona clinical interview rating scale. Educational and psychological Measurement. 1977;37:1031-8.

3. Barrows HS. Simulated patients in medical teaching. Can Med Assoc J. 1968 Apr 6;98(14):674-6.

4. Adamo G. Simulated and standardized patients in OSCEs: achievements and challenges 1992-2003. Medical Teacher. 2003 May;25(3):262-70.

5. Norman GR, Tugwell P, Feightner JW. A comparison of resident performance on real and simulated patients. Journal of Medical Education. 1982/09/01 ed1982. p. 708-15.

6. Cleland J, Abe K, Rethans J. The Use of Simulated Patients in Medical Education. In: Education AGiM, editor. Dundee: AMEE Guide; 2010.

7. Wallace P. Coaching standardized patients for use in assessment of clinical competence. New York: Springer Publishing Company; 2007.

8. Wind LA, Van Dalen J, Muijtjens AMM, Rethans J. Assessing simulated patients in an educational setting:the MaSP (Maastricht Assessment of Simulated Patients. Medical Education. 2004;38:39-44.

9. Schlegel C, Woermann U, Rethans JJ, van der Vleuten C. Validity evidence and reliability of a simulated patient feedback instrument. BMC Medical Education. 2012;12:6.

10. Bouter S, van Weel-Baumgarten E, Bolhuis S. Construction and validation of the Nijmegen Evaluation of the Simulated Patient (NESP): assessing simulated patients' ability to role-play and provide feedback to students. Acad Med. [Research Support, Non-U.S. Gov't Validation Studies]. 2013 Feb;88(2):253-9.

11. ASPE. Association of Standardized Patient Education. Altamonte Springs: ASPE; 2015 [cited 2013-2015]; Available from: http://www.aspeducators.org.

12. Nestel D, Tabak D, Tierney T, Layat-Burn C, Robb A, Clark S, et al. Key challenges in simulated patient programs: an international comparative case study. BMC Medical Education. [Comparative Study]. 2011;11:69.

13. Chang CS. Moderating effects of nurses'organizational support on the relationship between job satisfaction and organizational commitment. Western Journal of Nursing Research. 2014(April).

14. Tourangeau AE, Cranley LA. Nurse intention to remain employed: understanding and strengthening determinants. J Adv Nurs. [Research Support, Non-U.S. Gov't]. 2006 Aug;55(4):497-509.

15. Sempane M, Rieger $H$, Roodt G. Job satisfaction in relation to organizational culture. Journal of Industrial Psychologie. 2002;28(2):23-30.

16. Morgeson FP, Humphrey SE. Job and tean design: toward a more integrative conceptualization of workdesign. Research in Personal and Human Resources Management. 2008;27:39-91.

17. Meyers L. Social relationships matter in job satisfaction. American Psychological Association. 2007;38(4):14.

18. Oxford. Dictionary. Oxford: Oxford University Press; 2014; Available from: http://www.oxforddiction aries.com/definition/english/relationship.

19. Everett MR, May w, Tressler C, Main S. Recruitment, retention, and traini colaborative studyng of african and lationo standardized patient: A. Journal of the international Assosiation of Medical Sciene Educators. 2005;15(2):74-80.

20. Luthans F. Organizational behaviours. New York: Mc Graw Hill; 1977.

21. Warren T. Working pat-time: achieving a successful "work-life" balance? The British Journal of Sociolgy. 2004;55(1):99-122.

22. Schaufeli WB, Bakker $A B$, Van Rehenen W. How changes in Job demands and resources predict burnout, work engegement, and sickness absenteeinsm. Journal of Organizational Behaviour. 2009;30(7):893-917.

23. Toe TT, Murhadi WR, Lin W. Research study on the correlation between job satisfaction and emplyee motivation. International Journal of Business Management 2013;6(1):142-66. 
24. Kalleberg A. Work values and job rewards: A theory of jobsatisfaction. American Sociological Review. 1977;42:124-43.

25. Nestel D. Reflections on Simulated (Standardized) Patient Methodology: A Pillar of the Healthcare Simulation Community. In: Educators AoSP, editor. 13th Annual Association of Standardized Patient Educators Conference Indianapolis, USA: Association of Standardized Patient Educators; 2014.

26. Kuper A, Reeves S, Levinson W. An introduction to reading and appraising qualitative research. bmj. 2008;337:a288.

27. Jones M, Alony I. Guiding the use of Grounded Theory in Doctoral studies-an example from the Australian film industry. International Journal of Doctoral Studies. 2011;6:95-114.

28. Kennedy TJT, Lingard LA. Making sense of grounded theory in medical education. Medical Education. 2006;40(2):101-8.

29. Watling CJ, Lingard L. Grounded theory in medical education research: AMEE Guide No. 70. Medical Teacher. 2012;34(10):850-61.

30. Boyce M, Neale P. Conducting in-depth interviews: A guideline for designing and conducting in -depth interviews for evaluation. Watertown2006.

31. Glesne C. Becoming qualitative researchers. 4th ed. Boston: Pearson; 2011.

32. Janghorban R, Latifnejad Roudsari R, Taghipour A. Skype interviewing: the new generation of online synchronous interview in qualitative research. Int J Qual Stud Health Well-being. [Review]. 2014;9:24152.

33. Beck R, Schott K. The interplay pf project control and interorganizational learning: Mitigating effects on cultural differences in global multisource ISD outsourcing projects. Business\&Information System Engineering. 2012(4):183-92.

34. Rentsch J, Steel R. Construct and concurrent validation of the Andrews and Withey job satisfaction questionaire. Educ Psychol Measure. 1992;52:357-67.

35. Saldana J. The coding manual for qualitative research. 2nd ed. London: Sage; 2013.

36. Covington VM, Müeller K.J. Intrinsic versus extrinsic motivation; An approach/avoidence reformulation. Educational Psychology Review. 2001;13(2):157-76.

37. Goetz K, Campbell SM, Broge B, Dorfer CE, Brodowski M, Szecsenyi J. The impact of intrinsic and extrinsic factors on the job satisfaction of dentists. Community Dent Oral Epidemiol. [Research Support, Non-U.S. Gov't]. 2012 Oct; 40(5):474-80.

38. Herzberg F, Mausner B, Snyderman B. The motivation to work. 2nd ed. New York: John Wiley; 1959.

39. Harks B, Rakoczy K, Hattie J, Besser M, Klieme E. The effects of feedback on achievement, interest and self-evaluation: the role of feedback`s perceived usefulness. Educational Psychology. 2014;34(3):26990.

40. Hodges B, Regehr G, Hanson M, McNaughton N. Validation of an objective structured clinical examination in psychiatry. Acad Med. [Comparative Study]. 1998 Aug;73(8):910-2.

41. Bokken L, van Dalen J, Rethans JJ. The impact of simulation on people who act as simulated patients: a focus group study. Medical Education. 2006 Aug;40(8):781-6.

42. Woodward CA, Gliva-McConvey G. The effect of simulating on standardized patients. Acad Med. [Research Support, Non-U.S. Gov't]. 1995 May;70(5):418-20.

43. Boerjan M, Boone F, Anthierens S, van Weel-Baumgarten E, Deveugele M. The impact of repeated simulation on health and healthcare perceptions of simulated patients. Patient Education and Counseling. 2008 Oct; 73(1):22-7.

44. May J. Egoim, empathy, and self-other merging. Southern Journal of Philosophy. 2011;49:25-39.

45. Wallace J, Rao R, Haslam R. Simulated patients and objective structured clinical examintaions:review of their use in medical education. Advances in Psychiatric treatment. 2002;8:342-50. 



\section{CHAPTER 6}

\section{General Discussion}



The aim of this dissertation was to explore, in a first research question, the elements that improve the quality of SP performance when it comes to training methods and feedback, and, in a second question, how the quality of the SP methodology affects its stakeholders.

This final chapter focuses on how the chapters of this dissertation answer the research questions and how they interconnect to form a clarifying line of research; it also discusses the strengths and limitations of the thesis, and considers its implications for practice and future research.

To answer the first research question two studies were conducted, reported in chapters two and three. The study reported in chapter two focused on quality improvement in SP role training. Here, evidence was needed as to which training method is best for 'producing' well-trained SPs, i.e. the best method for enabling them to reproduce a standardized role script accurately. The study presented in chapter three focused on instruments designed to evaluate the quality of SP feedback to healthcare learners and therefore to improve students' learning. Thus the focus of the two studies was on quality improvement in the two key aspects of SPs' work: portraying a patient with a specific condition and giving feedback to future healthcare professionals.

\section{MAIN RESULTS AS REGARDS IMPROVING THE QUALITY OF TRAINING METHODS AND FEEDBACK}

Chapter two investigated how the quality of SP role training can be improved. The American Society for Quality (ASQ) defines quality as the characteristics of a product or service that bear on its ability to satisfy stated or implied needs (1). The findings of the study indicate that SP role training with the support of any kind of video helps to improve SP role performance, which is an implicit need in SP role training. This is in line with $\mathrm{Hu}(2)$, who states that video-based role training is highly instructive and provides a practical means of professional development. Training that uses videos with additional feedback from, e.g., the SP trainer, based on the training videos and tailored to each SP, is a highly effective educational tool in this training $(2,3)$. Hattie (4) states that the most effective forms of feedback are in the form of video combined with instructional feedback. Other studies agree that feedback, if it is informative and salient, is a key feature of learning (3-5).

In addition to good role performance, SPs must also be able to give useful performance feedback to healthcare students after the SP-student contact. Performance feedback is the evaluative information given by SPs, a facilitator or peer, with the intention of improving healthcare students' understanding of concepts or aspects of their performance (6). Chapter three focused on the quality of SP feedback to students. A key feature of performance feedback is its relevance and effects on learning (5). Generally, feedback is described as hard to give and hard to take (7). This also 
applies to SPs, who are challenged by having to give performance feedback to the student after an encounter, but who themselves (should) receive feedback from their SP trainer on the quality of their feedback. Using a valid and reliable instrument such as the 'modified Quality of Simulated Patient Feedback Form' (mQSF), which is described in chapter three, measures the quality of SP feedback to the student. At the time the MQSF was validated, one instrument for assessing the quality of SP performance was mentioned in the literature, namely the "Maastricht Assessment of Simulated Patients" (MaSP) (8). The MaSP has two subscales and assesses both the quality of SP feedback and the authenticity of SP performance during a simulated consultation. As there was a need to assess the quality of SP feedback in-depth, the mQSF was created as a respectable alternative to the MaSP, because it focuses fully on the quality of the SP feedback. In addition, some items of the MaSP are too specific and therefore irrelevant for other institutions. Nowadays, in the literature, there are more instruments with which to assess SPs' feedback quality, such as the Nijmegen Evaluation of the Simulated Patient (NESP) (9). SP trainers should make use of the instrument that serves their purpose and best fits their context.

There is overwhelming evidence that interpersonal skills for encounters between a healthcare professional and a patient can be taught and learnt (10). Thus high quality feedback on student performance or behavior in these encounters should impact students' learning and subsequent performance positively $(4,5)$. One of the strongest triggers of behavior change is performance feedback (11), i.e. information provided by an agent (e.g. teacher, peer, supervisor etc.) about aspects of someone's performance or understanding (4). With the help of performance feedback from the SP to the healthcare student, it is expected that the behavior of the student will change for the better (4). It is of course a different question whether this change, which occurs in an educational setting, is transferable or noticeable in clinical practice.

\section{MAIN RESULTS AS REGARDS HOW IMPROVED QUALITY IMPACTS ITS STAKEHOLDERS}

To answer the second research question regarding how the quality of SP training affects stakeholders, we conducted two additional studies, reported in chapters four and five. In these studies, we tested the assumption that good SP performance in terms of both role-play and feedback has a positive impact on healthcare students' performance with real patients in real practice.

In chapter four we investigated the impact of SP encounters on students' stakeholders (real patients, clinical supervisors, students themselves) in clinical practice. The findings of the research show that the interpersonal skills of those students who had done an SP encounter and received performance feedback from the SP, were rated higher by real patients and clinical supervisors than the control group who had done 
no encounter with an SP. Interestingly, these findings contrast with the students' own perception. The students themselves did not perceive their interpersonal skills as being improved after the SP encounter. One reason for this could be that the students, who answered the questionnaire before their first internship in clinical practice, were not aware of what they had learned with SPs. It is probable that they accumulate this knowledge/experience as implicit knowledge, remember and transfer complex information without having an awareness of what actually has been learned (12) and yet are able to retrieve and use this knowledge in the clinical context (13). According to Kirkpatrick \& Kirkpatrick's book "Evaluating Training Programs" (14) and the investigation of van den Eertwegh (15), a precondition for healthcare student change is that the learner becomes conscious of his/her own behavior, and develops an understanding of the need to change and a desire to change. In addition, learners should be well prepared by their educators for their SP encounter; i.e. students should be informed as to what to expect and what they should do (16). Learning always involves achieving integrated sets of learning goals and multiple performance objectives (16). Thus healthcare students should be informed of what is expected of them and the learning environment should be a motivating one, which could be achieved with good quality SP feedback. Other aspects to prepare students for an SP encounter could include concepts of the learner's self-reflection after a SP encounter so there will be sustainable results when students do their internship in clinical practice.

In chapter five, SPs' perspectives on workplace satisfaction and workplace relationships were investigated. SP job requirements have changed in recent years, becoming more demanding. While the original emphasis was only on portraying a patient, other tasks such as providing quality feedback after students encounter or role-performance according to a standardized role-script in assessment, e.g. in an OSCE, have become important. SP trainers, who are responsible for SPs' well-being in their workplace, can facilitate SPs' work by being responsible that students are properly prepared for SP encounters. SPs can cope with their tasks and current requirements well when both intrinsic (e.g. appreciation, feedback, opportunities to learn and develop) and extrinsic (e.g. job security, salary, work environment) motivators, are considered. In addition the working atmosphere should best be marked by a trustful and supportive relationship with the SP trainer. Hattie (4) states that teachers who build up relationships with their students, and support them with different and better learning strategies are described by the students as the best teachers. The attributes described by Hattie (4) can be transferred to SP trainers, who are responsible for SP learning, workplace relationships and SP quality performance. 


\section{IMPLICATIONS FOR PRACTICE}

Schools of health professions usually have their own SP programs composed of SP program directors, coordinators and trainers. SP coordinators are mainly responsible for administrative issues such as recruitment policy, development and maintenance of the database, SPs welfare, hospitality etc. SP trainers on the other hand are responsible for SP training, the assessment of training, evaluation of the SP program, etc. (17). It is assumed that SP trainers are key persons in an SP program and thus have considerable responsibility. To deal with this responsibility, SP trainers need to be supported and encouraged by their supervisors e.g. program directors to improve or maintain the quality of SP performance. The knowledge of best practice standards, as described by the International Nursing Association for Clinical Simulation and Learning (INACSL) (18), such as: advancing the science of simulation, sharing best practices, and providing evidence-based guidelines for implementation and training must important aspects of the work of a SP trainer. To learn best practice, SP trainers should profit from associations like the Association of Simulated and Standardized Patient Educators (ASPE) (19), where continuous education to SP-trainers is provided in the form of specific information on ASPE's webpages, webinars and annual conferences. Associations such as INACSL, ASPE and others provide detailed processes for evaluating and improving simulation operating procedures and deliver methods that every SP team will benefit from. Even though it is costly to send SP trainers to national and international conferences, the return on investment should ultimately become noticeable in the quality of SP performance. Not only educating the SP trainer, but also evaluating the SP trainer's work should be part of the concept of a SP program. Evaluating an SP trainer's work is not accurate enough if the only measuring point is the quality of SP performance. Multisource feedback that comes from the SP trainers immediate work circle, such as SPs, peers and students as well as self-evaluation should be used in the evaluation. Multisource feedback helps the individuals to get a broader perspective as to how they are perceived by others, provides a more holistic view of their performance, and is perceived as being more valid and objective as it is collected from varied sources (20). A multisource feedback evaluation also has its limitations; the SP-pool should be large enough, otherwise anonymity is not guaranteed. Student learning is one of the main goals of the use of SPs in health profession education. Due to its authenticity it provides students with the opportunity to transfer what has been learned into clinical practice. But what happens when students start with their internship in clinical practice? How much transfer of what has been learned occurs? Kirkpatrick \& Kirkpatrick mention that learners cannot change their behavior until they have an opportunity to do so (14). Even a learner has an opportunity to apply the learned; he or she will not do it immediately. In fact, after an SP encounter, change in students' behavior may take time after the first opportunity of practice (14). Student learning continues in clinical practice. Acquisition of knowledge and skills should be viewed as an ongoing 
process of exchange between the learner and his/her environment (21). An encouraging, demanding and rewarding educational environment in which the value of communication skills is recognized and in which support is institutionalized with appropriate feedback from role models supports the learner in accomplishing the desired change $(14,22)$.

\section{STRENGTH AND LIMITATION}

Strength of this dissertation is that it adds empirical data to important assumptions and suggestions concerning the quality of SP performance, as it emphasizes the quality of SP role training and of SP feedback to the student. Quality improvement is particularly important for SP trainers, because it gives them an empirical orientation with which to instruct and teach SPs more efficiently. It is assumed that the improved quality will have a positive impact on SP programs, SP trainers, coordinators and other stakeholders such as students and patients. In addition, the indications and explanations on how to treat SPs so that they are motivated and engaged in their work could be of great value to SP programs, their directors, coordinators and trainers. Furthermore, it has only been supposed up to now that use of SPs has a positive impact on patients because it improves healthcare students' professional communication. The evidence presented in this dissertation provides SP program directors with supporting argumentation to build up or maintain an SP program.

A limitation of this thesis is that all studies were conducted within the setting of the undergraduate-nursing curriculum of the Bern Centre of Higher Education in Nursing, Bern, Switzerland. It is therefore possible that the findings are not generalizable to all settings that use SPs. Further research should therefore be conducted on the quality of SP performance and its impact on stakeholders in other settings, as healthcare education systems vary in different institutions and countries. For example, as the educational system for nurses in Switzerland is a dual system (i.e., the training takes place in two places, at the school of nursing in higher education and at the hospital), it would be interesting if a non-dual educational system such as a university were to come to the same results.

Chapters two to five make us aware that student learning interdepends on a number of factors. Figure 1 illustrates that the success of SP methodology interdepends on the quality of SP performance and the quality of the SP trainer, but also on healthcare students' desire to change, their ability to transfer what has been learned into clinical practice, and the role-models students encounter during their internships. 


\section{FUTURE RESEARCH}

For future research, it would be worthwhile to investigate which aspects influence student learning most, and to what extent student learning is influenced by the educational environment, e.g. supervisors as role-models in clinical practice, as they are key to students' learning, because they guide and support learners to understand and achieve their objectives (23).

To conclude, quality and patient safety are dominant themes on any health care agenda (7). An efficient healthcare system aims to deliver safe and highly qualified patient care from all its healthcare professionals. The use of SPs in training and assessing students in the health care professions supports those aims, allowing them to explore and demonstrate technical skills and communication in a safe environment without causing harm to real patients and without fear of mistakes. SPs are thus valuable partners in the training of health professionals. We need to understand their contribution and maintain its high quality.

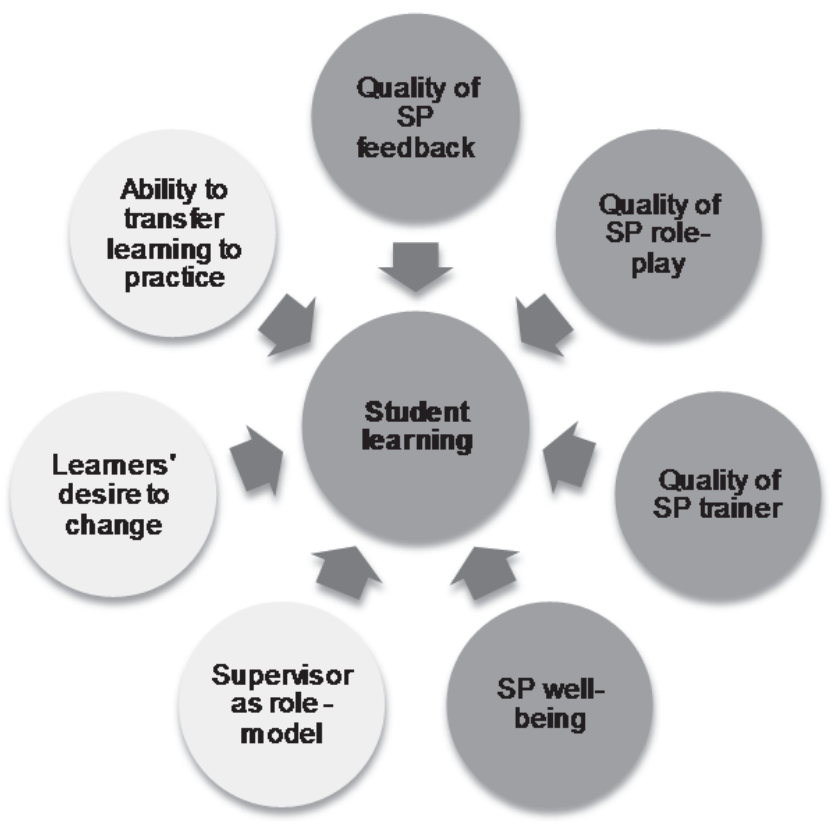

Figure 1: The success of SP methodology interdepends on the quality of SP performance and the quality of the SP trainer, but also on learners' desire to change, the ability to transfer what has been learned into clinical practice, and the role-models students encounter during their internships. 


\section{LITERATURE}

1. ASQ. The Global Voice of Quality. Milwaukee: ASQ; 2015; Available from: http://asq.org/index.aspx.

2. Hu YY, Peyre SE, Arriaga AF, Osteen RT, Corso KA, Weiser TG, et al. Postgame analysis: using videobased coaching for continuous professional development. J Am Coll Surg. [Research Support, N.I.H., Extramural Research Support, Non-U.S. Gov't]. 2012 Jan;214(1):115-24.

3. Harks B, Rakoczy K, Hattie J, Besser M, Klieme E. The effects of feedback on achievement, interest and self-evaluation: the role of feedback's perceived usefulness. Educational Psychology. 2014;34(3):269-90.

4. Hattie J., Timperley H. The power of feedback. Review of Educational Research. 2007;77(1):81-112.

5. van de Vijver I, Ridderinkhof KR, de Wit S. Age-related changes in deterministic learning from positive versus negative performance feedback. Neuropsychol Dev Cogn B Aging Neuropsychol Cogn. 2015;22(5):595-619.

6. Palaganas J, C.,, Maxworthy J, C.,, Epps C, A.,, Mancini ME, editors. Defining Excellence in Simulation Programs. First Edition ed. Philadelphia: Society for Simuation in Healthcare; 2015.

7. Nestel D, Bearman M, editors. Simulated Patient Methodology. Oxford: Wiley Blackwell; 2015.

8. Wind LA, Van Dalen J, Muijtjens AMM, Rethans J. Assessing simulated patients in an educational setting:the MaSP (Maastricht Assessment of Simulated Patients. Medical Education. 2004;38:39-44.

9. Bouter S, van Weel-Baumgarten E, Bolhuis S. Construction and validation of the Nijmegen Evaluation of the Simulated Patient (NESP): assessing simulated patients' ability to role-play and provide feedback to students. Acad Med. [Research Support, Non-U.S. Gov't Validation Studies]. 2013 Feb;88(2):253-9.

10. Aspegren K. BEME Guide No. 2: Teaching and learning communication skills in medicine-a review with quality grading of articles. Medical Teacher. 1999;21(6):563-70.

11. Young W, Davis M, Mc Neill IM, Malhorta B, Russell S, Unsworth K, et al. Changing Behaviour: Successful Environmental Programmes in the Workplace. Business Strategy and the Environment. 2013(Published online in Wiley Online Library):1-14.

12. Schacter D, L. Imlicit Memory: History and Current Status. Journal of Experimental Psychology. 1987;13(3):501-18.

13. Heiberg Engel PJ. Tacit knowledge and visual expertise in medical diagnostic reasoning: implications for medical education. Medical Teacher. 2008;30(7):e184-8.

14. Kirkpatrick DL, Kirkpatrick JD. Evaluating Training Programs. San Francisco: Berret-Koehler 2006.

15. van den Eertwegh V, van der Vleuten C, Stalmeijer R, van Dalen J, Scherpbier A, van Dulmen S. Exploring residents' communication learning process in the workplace: a five-phase model. PLoS One. 2015;10(5):e0125958.

16. van Merrienboer JJ, Clark RE, de Crook MB. Blueprints for Complex Learning: The 4C/ID-Model. ETR\&D. 2002;50(2):39-64.

17. Cleland J, Abe K, Rethans J. The Use of Simulated Patients in Medical Education. In: Education AGiM, editor. Dundee: AMEE Guide; 2010.

18. INACSL. International Nursing Association for Clinical Simulation and Learning. Tampa: INACSL; 2015; Available from: http://www.inacsl.org/i4a/pages/index.cfm?pageid=1.

19. ASPE. Association of Standardized Patient Education. Altamonte Springs: ASPE; 2015 [cited 2013-2015]; Available from: http://www.aspeducators.org.

20. Atkins P, Wood R. Self-versus others' ratings as predictors of assessment center ratings: Validation evidence for 360-degree feedback programs. Personnel Psychology,. 2002;4(55):871-904.

21. van den Eertwegh V, van Dulmen S, van Dalen J, Scherpbier A, Vleuten vd. Learning in context: identifying gaps in research on the transfer of medical communication skills to the clinical workplace. Patient Educ Couns. 2013;90(2):184-92.

22. van den Eertwegh V, van Dalen J, van Dulmen S, van der Vleuten C, Scherpbier A. Residents' perceived barriers to communication skills learning: comparing two medical working contexts in postgraduate training. Patient Education and Counseling. 2014 Apr;95(1):91-7.

23. Frank JR, Danoff D. The CanMEDS initiative: implementing an outcomes-based framework of physician competencies. Medical Teacher. 2007 Sep;29(7):642-7. 

Summary 


\section{CHAPTER 1: INTRODUCTION}

Chapter 1 introduces the main concepts of this thesis, discusses its background and presents the problem statement and two main research questions. The central investigation problem concerns is quality improvement in the performance of simulated and /or standardized patients (SP) in terms of training methods and their feedback to healthcare students as well as the impact of this improvement on stakeholders. This dissertation has sought to answer the following research questions: 1) "What elements improve the quality of SP performance when it comes to training methods and feedback?" 2): "How does the quality of the SP methodology affect its stakeholders?".

Chapter 1 first explains the relevance of paying attention to the use of simulation in the context of health profession education. Simulations allow learning opportunities to be practiced in a protected environment, which puts the learners in simulated, quasiauthentic safe situations without risks for the patients and consequences for the learners. There are different modalities of simulation, such as simulation technology that replicates the whole body or parts of bodies (simulators/part-task trainers), simulation of/as real human beings and combinations of these. Simulation of/as real human beings, also referred to as standardized patients or simulated patients (SPs), is a methodology whereby healthy persons are trained to act as real patients and to simulate a set of patient symptoms or problems for their use in healthcare education. SPs can be used as simulated patients (emphasis on authenticity) to support the learning of students and/or as standardized patients (emphasis on standardization) for assessment purposes. This chapter emphasizes the importance of SPs' role-training, as they are used in Objective Structured Clinical Examinations (OSCE). SPs must give an accurate and consistent presentation of the patient case that does not vary from student to student. Determining which training methods lead to qualitatively better accuracy of SP performance and what impact training with video can have during SP role-training are key areas for further scientific inquiry. Chapter 1 further focuses on the quality of SPs' oral feedback to students after a simulated clinical encounter. The quality of SP feedback must be monitored, because it is assumed that feedback can have a positive effect on student performance in clinical practice and thus later on its stakeholders, i.e. real patients or clinical supervisors of the students. The chapter also describes the well-being of the SPs themselves. As SPs are considered to play an essential part in the education of future healthcare providers, yet face major challenges in their work of role playing and giving feedback, it is important to know whether SPs feel supported by the SP trainer and are satisfied with their workplace. It is concluded that in a world where efficiency is important, purposeful and continuous quality improvement of SP performance and its evaluation is essential to maintain the use of SPs as a powerful method for learning and assessment. To answer the two main research questions of this dissertation we conducted four empirical studies, which comprise chapters 2 through 5 . The first research question emphasizing quality improvement is answered 
by Chapters 2 and 3. The second research question focusing on the impact of improved quality on healthcare stakeholders is informed by Chapters 4 and 5 .

\section{CHAPTER 2: THE USE OF VIDEO IN STANDARDIZED PATIENT TRAINING TO IMPROVE PORTRAYAL ACCURACY: A RANDOMIZED POST-TEST CONTROL GROUP STUDY}

Chapter 2 presents the effect of different types of SP video training on the accuracy of SP portrayal in a randomized post-test control group study design. The chapter presents theoretical information about the use of video instruction in general, and reveals an evidence gap concerning the use of videos in instructing SPs for role-portrayal. A comparison was made between three groups of 12 SPs, each with different types of video training, and one control group of 12 SPs without any video use in SP training. The three intervention groups used role-modeling video, performance-feedback video or a combination of both. The results show that SPs trained by video showed significantly better role accuracy than SPs trained without video over the four sequential portrayals, and there was no difference between the three types of video training. The chapter ends by concluding that the use of video during SP training enhances the accuracy of SP portrayal compared with no video, regardless of the type of video intervention used.

\section{CHAPTER 3: VALIDITY EVIDENCE AND RELIABILITY OF A SIMULATED PATIENT FEEDBACK INSTRUMENT}

Chapter 3 is focused on SPs' oral feedback to healthcare students after a simulated clinical encounter. In this chapter it is explained why the quality of SP feedback must be monitored, especially because it is well known that feedback can have a profound effect on student performance. A lack of valid and reliable instruments to assess the quality of SP feedback to healthcare students is established. The 'modified Quality of Simulated Patient Feedback Form' (mQSF) was created as a respectable alternative to an already existing instrument, the 'Maastricht Assessment of Simulated Patient' (MaSP), because it focuses fully on the quality of SP feedback. The content validity and generalizability of the mQSF were investigated. Content validity of the mQSF was assessed by inviting experts to rate the importance of the mQSF items. Moreover, generalizability theory was used to examine the reliability of the mQSF. The experts judged all but two items of the mQSF as important. A generalizability coefficient of 0.77 was established with two judges observing one encounter. 
One shortcoming of the study is the fact that the original instrument was translated into another language. Translating an instrument always involves the risk that the original idea expressed in an item may not be conveyed fully and accurately. Cultural differences can also hamper accurate representation of item content. Considering the limitations, the chapter concludes that the findings for content validity and reliability with two judges suggest that the MQSF is a valid and reliable instrument for assessing the quality of feedback to healthcare students provided by simulated patients.

\section{CHAPTER 4: EFFECTS OF COMMUNICATION TRAINING ON REAL PRACTICE PERFORMANCE: A ROLE-PLAY MODULE VERSUS A STANDARDIZED PATIENT MODULE}

Chapter 4 is a randomized post-test-only control group design with first year nursing students and describes how the effectiveness of teaching modules involving SPs affects stakeholders. The research question here was whether students who have had an SP encounter in a skills lab perform better in real clinical practice with real patients. Two clinical training modules were compared: an SP module and a role-play module. The SP module involved SPs, whereas the role-play module consisted of peer role-plays. A posttest was conducted with questionnaires, which were distributed at the start of the students' first clinical practice rotation to real patients and clinical supervisors. The latter were asked to fill in the questionnaires anonymously. Students rated their applied skills in a self-efficacy questionnaire. The results showed no significant differences between the intervention and control group in perceived self-efficacy and patient ratings. However, the clinical supervisors rated the communication skills of the students of the intervention group as being superior to the control group. To conclude, teaching modules involving SPs are superior to peer role-playing. Moreover, in contrast to clinical supervisors, patients do not seem to discriminate among students' communication skills adequately, and the measurement of students' perceived self-efficacy does not contribute to the detection of differences between the two methods of communication skills training.

\section{CHAPTER 5: STANDARDIZED PATIENTS' PERSPECTIVES ON WORKPLACE SATISFACTION AND WORK-RELATED RELATIONSHIPS: A MULTI-CENTRE STUDY}

Chapter 5 emphasizes SPs' well-being. The use of Standardized Patients (SP) in healthcare education has grown in the last fifty years. In addition, the requirements for SPs have increased steadily and thus the work of SPs has become more difficult and 
demanding. The effects of this job development on SPs and their programs were investigated. A qualitative research design, with semi-structured Individual in-depth Interviews (IDIs) to understand the reactions, values, and perceptions that underlie and influence SP behavior was conducted. To cover SP perspectives from more than one SP program, SPs from eight different nursing schools and medical schools in Switzerland were asked to participate. It was found that SPs feel motivated, engaged and willing to invest effort in their task and do not mind demands increasing as long as the social environment in SP program is supportive and motivating. The role of the SP trainer and the use of feedback is considered pivotal. To conclude, SP program require concepts in which the SP perspective has been integrated to better serve SPs' well-being.

\section{CHAPTER 6 DISCUSSION}

Chapter 6 constitutes the discussion chapter of this thesis. The first part of the chapter relates the main findings to four gaps in evidence in existing research. Our findings reduce the missing evidence in the quality of SP performance, when it comes to roletraining and feedback. Firstly, the importance of feedback is discussed. Feedback in combination with video, based on a relevant aspect of training and tailored to each learner, is a highly effective educational tool for training. As feedback is important for learning, high quality feedback must be practiced and monitored. This also applies to SPs, who are challenged by having to give feedback to the student after an encounter, but who also receive feedback from their SP trainer, assessed by valid instruments, on the quality of their feedback.

It is assumed that in the case of SP feedback from the SP to a healthcare student, the student's behavior will change for the better. However, it is important to point out that a precondition for healthcare student change is that the learner should become conscious of his/her own behavior, understand the need to change and have the desire to change. In addition, students should be well prepared by their educators for their SP encounter; i.e. students should be informed as to what to expect and what they should do. An encouraging, demanding and rewarding educational environment in which the learner is supported to accomplish the desired change, helps students to transfer their newly acquired knowledge, skills and attitudes into clinical practice.

The second part of the chapter suggests implications for practice. It is assumed that SP trainers are key persons in an SP program, with considerable responsibility. To deal with this responsibility, SP trainers should benefit from Associations like the Association of Standardized Patient Educators (ASPE), where continuous education is provided in the form of specific information on their webpages, webinars and annual conferences. Associations such as ASPE and others provide a detailed process for evaluating and improving simulation operating procedures and deliver methods that every SP team will benefit from. 
In conclusion quality and patient safety are dominant themes on any healthcare agenda. An efficient healthcare system aims to deliver safe and highly qualified patient care from all its healthcare professionals. The use of SPs in training and assessing students in the healthcare professions supports those aims, allowing them to explore and demonstrate technical skills and communication in a safe environment without causing harm to real patients and without fear of mistakes. 
Samenvatting 


\section{HOOFDSTUK 1: INTRODUCTIE}

Hoofdstuk 1 introduceert de hoofdbegrippen die in dit proefschrift worden gehanteerd, bespreekt zijn achtergrond en presenteert de probleemstelling en twee onderzoeksvragen. Centraal in dit onderzoek staat enerzijds de verbetering van de kwaliteit van optreden van simulatie- en/of gestandaardiseerde patiënten ( $\mathrm{SP}^{\prime} \mathrm{S}$ ) door te kijken naar trainingsmethoden en feedback van deze SP's aan studenten in de gezondheidszorg en anderzijds de invloed van deze verbetering op belanghebbenden. Het proefschrift poogde de volgende onderzoeksvragen te beantwoorden: 1) Welke elementen met betrekking tot trainingsmethoden en feedback helpen de kwaliteit van optreden van SP's te verbeteren?, 2) Welke invloed heeft de kwaliteit van de gehanteerde SPmethodiek op belanghebbenden?

In hoofdstuk 1 wordt eerst uitgelegd waarom het zo belangrijk is dat in het gezondheidszorgonderwijs aandacht wordt besteed aan het gebruik van simulatie. Dankzij simulaties kunnen leermomenten in een beschermde omgeving worden geoefend: zij plaatsen studenten in nagebootste, bijna echte, veilige situaties zonder risico's voor patiënten en gevolgen voor studenten. Er bestaan verschillende vormen van simulatie, zoals simulatietechnieken waarbij het hele lichaam of delen daarvan worden nagebootst (simulatoren/deeltaaktrainers), simulatie van/als echte mensen en een combinatie hiervan. Simulatie van/als echte mensen, ook wel simulatie- of gestandaardiseerde patiënten genoemd, is een methodiek waarmee gezonde mensen getraind worden zich voor te doen als echte patiënten en een aantal patiëntsymptomen of klachten na te bootsen, zodat zij ingezet kunnen worden in het gezondheidszorgonderwijs. SP's kunnen worden ingezet als simulatiepatiënten (waarbij de nadruk ligt op echtheid) om het leren van studenten te bevorderen en/of als gestandaardiseerde patiënten (nadruk op standaardisering) voor toetsdoeleinden. In dit hoofdstuk wordt het belang benadrukt van training van SP-rollen zoals deze gespeeld worden tijdens stationsexamens, ook wel bekend als Objective Structured Clinical Examinations (OSCE's). SP's dienen een nauwkeurige en consequente afspiegeling te geven van de patientcasus en daarbij niet van student tot student af te wijken. De vraag welke trainingsmethoden de nauwkeurigheid van optreden van SP's kwalitatief verbeteren en welke invloed training van SP-rollen op basis van video's kan hebben vormen de voornaamste uitgangspunten voor nader wetenschappelijk onderzoek. Hoofdstuk 1 richt zich verder op de kwaliteit van mondelinge feedback van SP's aan studenten na afloop van een nagespeeld ziekenhuisconsult. De kwaliteit van SP-feedback dient bewaakt te worden, aangezien verondersteld wordt dat feedback een positieve invloed kan hebben op het functioneren van de student in de klinische praktijk en daarmee dus ook op toekomstige belanghebbenden, d.w.z. echte patiënten of de klinisch begeleiders van studenten. Het hoofdstuk beschrijft ook het welbevinden van de SP's zelf. Aangezien SP's een essentiële rol spelen in het onderwijs van toekomstige gezondheidszorgverleners, maar bij het spelen van hun rol en het geven van feedback voor grote uitdagin- 
gen komen te staan, is het belangrijk te weten of SP's zich gesteund voelen door hun SP-trainer en tevreden zijn met hun werkplek. Geconcludeerd wordt dat in een wereld waarin efficiëntie voorop staat, het van essentieel belang is dat de kwaliteit van optreden van SP's doelbewust en doorlopend verbeterd en geëvalueerd wordt, opdat de inzet van SP's als effectieve leer- en toetsmethode kan blijven dienen. Om de twee belangrijkste onderzoeksvragen van dit proefschrift te kunnen beantwoorden, voerden we vier empirische studies uit die hoofdstuk 2 tot en met 5 beslaan. De eerste onderzoeksvraag die nader ingaat op kwaliteitsverbetering wordt in hoofdstuk 2 en 3 beantwoord.

De tweede onderzoeksvraag over de gevolgen van kwaliteitsverbetering op belanghebbenden in de gezondheidszorg wordt door hoofdstuk 4 en 5 nader behandeld.

\section{HOOFDSTUK 2: HET GEBRUIK VAN VIDEO'S BIJ HET TRAINEN VAN GESTANDAARDISEERDE PATIËNTEN TER VERBETERING VAN DE NAUWKEURIGHEID VAN DE ROLVERTOLKING: EEN GERANDOMISEERDE STUDIE MET NAMETING EN CONTROLEGROEP}

Hoofdstuk 2 toont het effect van verschillende typen SP-videotrainingen op de nauwkeurigheid van de SP-vertolking aan de hand van een gerandomiseerde studieopzet met nameting en controlegroep. Het hoofdstuk verschaft theoretische informatie over het gebruik van video-onderwijs in het algemeen, en laat zien dat er een tekort bestaat aan bewijs omtrent het gebruik van video's bij het aanleren van SP-rollen. We vergeleken drie groepen van 12 SP's die elk een andere videotraining hadden ondergaan, en een controlegroep van 12 SP's die bij hun training geen video's te zien hadden gekregen. De drie interventiegroepen kregen respectievelijk rolmodellen, feedback op het optreden, of een combinatie van beide te zien op video. De resultaten laten zien dat SP's die getraind werden met behulp van video's de vier opeenvolgende rollen aanzienlijk nauwkeuriger wisten te vertolken dan de SP's die geen video's te zien hadden gekregen. Ook bleken de drie groepen die elk een andere videotraining hadden ondergaan geen onderlinge verschillen te vertonen. Het hoofdstuk sluit af met de conclusie dat het gebruik van video's bij SP-trainingen de nauwkeurigheid van de rolvertolking kan verbeteren ten opzichte van geen video's, ongeacht welk type video-interventie gebruikt wordt. 


\section{HOOFDSTUK 3: BEWIJS VOOR DE VALIDITEIT EN BETROUWBAARHEID VAN EEN SIMULATIEPATIËNTENFEEDBACKINSTRUMENT}

Hoofdstuk 3 richt zich op de mondelinge feedback van SP's aan studenten in de gezondheidszorg na afloop van een nagespeeld ziekenhuisconsult. In dit hoofdstuk wordt uitgelegd waarom de kwaliteit van SP-feedback bewaakt dient te worden, vooral omdat het algemeen bekend is dat feedback een grote uitwerking kan hebben op het functioneren van de student. Geconstateerd wordt dat er een gebrek is aan valide en betrouwbare instrumenten waarmee de kwaliteit van SP-feedback aan studenten in de gezondheidszorg kan worden gemeten. De "aangepaste Kwaliteit van simulatiepatiëntenfeedback-vragenlijst $\left(\mathrm{mQSF}^{1}\right)$ " werd opgesteld als waardig alternatief voor een al bestaand instrument, de "Maastrichtse beoordeling van simulatiepatiënten (MaSP)", omdat deze zich volledig richt op de kwaliteit van SP-feedback. De inhoudsvaliditeit en generaliseerbaarheid van de mQSF werden onderzocht. Om de inhoudsvaliditeit te kunnen bepalen, vroegen we deskundigen om het belang van elk van de mQSF-items aan te geven. Verder werd generaliseerbaarheidstheorie gebruikt om de betrouwbaarheid van de mQSF na te gaan. Op twee na, werden alle items van de mQSF relevant bevonden door de deskundigen. Een generaliseerbaarheidscoëfficiënt van 0,77 werd bereikt bij inzet van twee observerende beoordelaars per consult.

Een beperking van deze studie is het feit dat het oorspronkelijke instrument naar een andere taal was vertaald. Bij vertaling van een instrument bestaat altijd het risico dat de oorspronkelijke boodschap die een item uitdrukt niet volledig en nauwkeurig wordt overgebracht. Ook kunnen cultuurverschillen een juiste weerspiegeling van de iteminhoud in de weg staan.

Met inachtneming van deze beperkingen concludeert het hoofdstuk dat de bevindingen met betrekking tot de inhoudsvaliditeit en betrouwbaarheid bij twee beoordelaars erop wijzen dat de mQSF een valide en betrouwbaar instrument is voor het meten van de kwaliteit van door simulatiepatiënten gegeven feedback aan studenten in de gezondheidszorg.

HOOFDSTUK 4: EFFECTEN VAN COMMUNICATIETRAINING OP HET FUNCTIONEREN IN DE ECHTE PRAKTIJK: EEN ROLLENSPELMODULE TEGENOVER EEN GESTANDAARDISEERDE PATIËNTMODULE

Hoofdstuk 4 betreft een gerandomiseerde studieopzet met controlegroep en alleen een nameting. De studie werd uitgevoerd met eerstejaars verpleegkundestudenten en

\footnotetext{
${ }^{1} \mathrm{mQSF}=$ modified Quality of Simulated Patient Feedback Form.

${ }^{2}$ MaSP $=$ Maastricht Assessment of Simulated Patients
} 
beschrijft welke invloed de effectiviteit van onderwijsmodules met SP's heeft op belanghebbenden. In dit geval was de onderzoeksvraag of studenten die al eerder een consult hadden geoefend met SP's in een skillslab beter functioneerden in de echte klinische praktijk met echte patiënten. Er werden twee klinische onderwijsmodules met elkaar vergeleken: een SP-module en een rollenspelmodule. Bij de SP-module waren SP's betrokken, terwijl de rollenspelmodule uit rollenspellen met medestudenten bestond. Een nameting werd uitgevoerd met vragenlijsten die aan het begin van de eerste klinische praktijkstage van studenten werden uitgereikt aan echte patiënten en klinisch begeleiders. Deze laatsten werden gevraagd anoniem een vragenlijst in te vullen. De studenten beoordeelden hun eigen toegepaste vaardigheden aan de hand van een vragenlijst over zelfeffectiviteit. De resultaten laten zien dat de interventie- en controlegroep niet significant van elkaar verschilden wat de zelf- en patiëntbeoordelingen betreft. Klinisch begeleiders daarentegen oordeelden dat de studenten uit de interventiegroep beter communicatief vaardig waren dan de studenten uit de controlegroep. Kortom, onderwijsmodules waarin SP's deelnemen verdienen de voorkeur boven rollenspellen met medestudenten. Bovendien lijken patiënten, in tegenstelling tot klinisch begeleiders, geen goed onderscheid te kunnen maken tussen studenten op basis van hun communicatievaardigheden en helpt het meten van zelfeffectiviteit niet om verschillen tussen de twee typen communicatievaardigheidstraining te detecteren.

\section{HOOFDSTUK 5: DE VISIE VAN GESTANDAARDISEERDE PATIËNTEN TEN AANZIEN VAN WERKPLEKTEVREDENHEID EN WERKRELATIES: EEN MULTICENTER STUDIE}

In hoofdstuk 5 ligt de nadruk op het welbevinden van SP's. In de afgelopen vijftig jaar werden Gestandaardiseerde Patiënten (SP's) steeds vaker ingezet in het gezondheidszorgonderwijs. Tegelijkertijd werd er steeds meer van hen verlangd, waardoor het werk van SP's moeilijker en veeleisender is geworden. Daarom onderzochten wij het effect van deze rolontwikkeling op SP's en de desbetreffende opleidingen. We verrichtten kwalitatief onderzoek met half-gestructureerde één-op-één diepte-interviews om de reacties, waarden en visies die achter het gedrag van SP's schuilgaan en dit beïnvloeden, te begrijpen. Om zicht te krijgen op de visies van SP's van meer dan één SPopleiding, nodigden we SP's van acht verschillende verpleegkunde- en medische opleidingen in Zwitserland uit om deel te nemen. Onze bevinding was dat SP's gemotiveerd en betrokken zijn, bereid zijn moeite te doen voor hun rol en het niet erg vinden als er steeds hogere eisen worden gesteld, mits de sfeer binnen de SP-opleiding aanmoedigend en motiverend is. In dit verband werden de rol van SP-docent en het gebruik van feedback als cruciaal gezien. 
Tot slot wordt geconcludeerd dat, omwille van het welbevinden van SP's, de SPopleiding rekening dient te houden met hun visie.

\section{HOOFDSTUK 6: DISCUSSIE}

Hoofdstuk 6 vormt het discussiehoofdstuk van dit proefschrift. In het eerste deel van het hoofdstuk worden de belangrijkste bevindingen gekoppeld aan vier aandachtspunten waarvoor bestaand onderzoek vooralsnog geen bewijs heeft geleverd. Onze bevindingen voorzien deels in het ontbrekende bewijs ten aanzien van de kwaliteit van het optreden van SP's wat betreft rollentraining en feedback. In de eerste plaats wordt het belang van feedback besproken. Feedback, indien gecombineerd met video, gericht op een relevant trainingsaspect en toegesneden op de student, is een zeer doelmatige leermethode voor training. Aangezien feedback belangrijk is voor het leerproces, dient goede feedback geoefend en bewaakt te worden. Dit geldt ook voor SP's, die niet alleen voor de uitdaging staan om de student feedback te geven na een consult, maar ook feedback op de kwaliteit van hun eigen feedback ontvangen van hun SP-docent, die daartoe valide instrumenten aanwendt.

Er wordt verondersteld dat wanneer een student in de gezondheidszorg feedback ontvangt van een SP, het gedrag van de student zal verbeteren. Een belangrijke randvoorwaarde voor deze gedragsverandering is echter dat de student zich eerst bewust dient te worden van zijn/haar gedrag, het nut van de verandering inziet en ook wíl veranderen. Daarnaast moeten docenten hun studenten goed voorbereiden op hun SP-consult, zodat studenten weten wat hen te wachten staat en hoe te handelen. Een bemoedigende, veeleisende en belonende leeromgeving waarin de student gestimuleerd wordt de gewenste verandering door te voeren helpt studenten om hun nieuwe opgedane kennis, vaardigheden en gedragingen over te brengen naar de klinische praktijk.

In het tweede deel van het hoofdstuk worden de mogelijke gevolgen voor de praktijk besproken. Verondersteld wordt dat SP-docenten een sleutelrol vervullen binnen een SP-opleiding, waarbij er veel verantwoordelijkheid op hen rust. Om deze verantwoordelijkheid te kunnen dragen, zouden SP-docenten hun voordeel moeten doen met lidmaatschap van verenigingen zoals de Vereniging van Gestandaardiseerde Patientopleiders $\left(\mathrm{ASPE}^{3}\right)$ die doorlopend onderwijs aanbieden in de vorm van specifieke informatie op hun websites, Webinars en jaarlijkse congressen. ASPE en andere soortgelijke verenigingen leveren gedetailleerde procesbeschrijvingen voor het evalueren en verbeteren van simulatiepraktijken, alsook methoden waarvan elk SP-team voordeel zal hebben.

\footnotetext{
${ }^{3}$ ASPE $=$ Association of Standardized Patient Educators
} 
Samengevat kan men stellen dat de thema's "kwaliteit" en "patiëntveiligheid" hoog op elke gezondheidszorgagenda staan. Een efficiënt zorgstelsel is erop geënt dat alle gezondheidszorgprofessionals veilige en hooggekwalificeerde patiëntenzorg verlenen. Dit doel wordt mede bereikt door SP's in te zetten in het onderwijs en bij de beoordeling van studenten in de gezondheidszorg, zodat studenten hun technische en communicatievaardigheden in een veilige omgeving kunnen oefenen en laten zien, zonder patiënten daarmee schade toe te brengen en bang te hoeven zijn voor fouten. 

Valorization 


\section{RELEVANCE}

The research presented in this doctoral thesis addresses topics about the quality of simulated patient (SP) performance in terms of role-play and feedback and also considers the impact of the improved quality on its stakeholders. The relevance of this research is explained by the two research questions that were put forward in the thesis.

It was shown that the quality of SP role-training can be improved. Our investigation confirmed that SP role-training with video positively affects the quality of SPs' role performance. SPs trained with the help of any kind of video are able to perform their role more accurately according to a standardized script. This is of great relevance when it comes to high stake examinations such as the Objective Structured Clinical Examination (OSCE), because students are afforded the possibility of a consistent presentation of the patient case.

As quality is defined as the characteristics of a product or service that bear on its ability to satisfy stated or implied needs, there was need for an instrument that monitors the quality of oral SP feedback to the healthcare student after an encounter. Our research into validating such an instrument was important because previously no such instrument existed. In the literature the importance of feedback is emphasized, as it fosters student learning. Monitoring the quality of SP feedback to healthcare students is therefore of major relevance to students' learning.

The question of how SP methodology affects real practice (real patients, clinical supervisors) is also important. Our research on the impact of the SP methodology in clinical practice has shown that healthcare students trained with SPs showed better communication skills with real patients than students who were trained with peer roleplay. These findings are important, as it is known that communication skills are of paramount importance for healthcare professionals working with patients. It is argued that without appropriate communication skills, the better part of the clinical efforts in medical care may be wasted. It has also been demonstrated that patient-centred communication improves diagnostic efficiency, physicians' and patients' satisfaction and treatment outcomes.

\section{TARGET GROUPS}

\section{Management in healthcare education}

It is assumed that administrators of universities and healthcare institutions are highly interested in quality and patient safety. This thesis presents empirical research contributing to quality and safety. Learning with SPs has a positive impact on healthcare students' communication skills in clinical practice. This is recognized not only by the 
patients but also by clinical supervisors who are responsible for students' learning during their internship in clinical practice. Students like to be trained with SPs, because it gives them the possibility to learn in a safe environment without harming real patients. It is further assumed that students prefer universities or other health education institutions, where they have the possibility to train in a skillslab with SPs. An SP program of good quality can be a motivating factor for students in choosing such an institution for their studies, which, on the other hand, could be an interesting aspect for administrators in gaining students for their educational institutions.

\section{SP trainers}

This thesis shows that the behaviours of SP trainers and SP coordinators are crucial for the quality of SP performance and the well-being of the SPs. They should be familiar of how SPs can be motivated for high quality performance and have expertise in the domain of engaging and working with SPs. Training and programme staff should also be knowledgeable regarding the needs of SPs, and possess interpersonal skills and have experience in development and advancement of SP education and research in the health sciences. Based on the results of the last study in this thesis, a non-static and context-adaptable SP oriented working spread-sheet (SOWSS) was developed. This may be relevant in supporting SP trainers and SP coordinators to plan and organize training events from an SP-centric point of view. It thus constitutes a good basis for setting up and maintaining SP programmes and conducting SP training sessions.

\section{Simulated Patients}

This thesis shows that research with SPs is rewarding. The research combines three studies using quantitative and one using qualitative methodology. In the qualitative study the SP perspective of their work place satisfaction was conducted in individual interviews SPs from different institutions. The results of the interviews indicated that they generally like feedback on their performance from the SP trainer. They also like to be well prepared for their role -training and appreciate it when the trainer delivers information about the illness they have to portray, so that they can act the role as authentically as possible. SPs like to be treated in a supportive manner. Also, intrinsic and extrinsic motivations are important for SPs so they are able to perform of high quality. To give SPs a platform to communicate their needs and listen to them is important and helps them to perform the way it is expected. 


\section{ACTIVITIES}

This thesis contains empirical studies conducted in the context of the undergraduate nursing programme at the Bern Centre of Higher Education in Nursing, Switzerland. Activities which were conducted associated with this thesis were three Swiss Conferences on Standardized and Simulated Patients and Simulations (SPSIM) in 2009, 2012 and 2014. The SPSIM Conference took place in close cooperation between healthcare institutions such as the universities and schools of nursing in Switzerland. In the concluding panel discussion at the SPSIM Conference in 2014, held at the Bern Centre of Higher Education in Nursing, in the presence of a delegate from the Swiss Federal Office of Public Health, visions of the future were discussed that should be pursued in further discussions. There was agreement among the participants and leaders of the institutions involved that it would be worthwhile to think about an inter-institutional skills and simulation strategy to pool common resources. The Swiss Federal Office of Public Health offered financial support for further development of the subject. In the summer of 2015, a nationwide survey was developed to evaluate the "status quo" of simulations in health profession institutions. The results formed the basis for a workshop on the development of Swiss inter-institutional collaboration on a national strategy for skills- and simulation which was conducted in November 2015, thus providing the basis for new development in the field of simulation and SPs. 


\section{Acknowledgments}


The journey through my PhD was a long one. I am grateful to everyone who has helped and supported me along the way. It is impossible to name everyone who has guided or encouraged me, so please forgive me if you are not mentioned.

My PhD supervisors have been brilliant. Especially Prof. Cees van der Vleuten and Prof. Jan-Joost Rethans, believed in me, supported and challenged me but also taught me an enormous amount over all those years. Also to Dr. Raphael Bonvin, who supported me onsite, I address my thanks. The speed of their response to my drafts was impressive and their ability to critique my work whilst still leaving my ego intact are hallmarks of quality academic supervision.

The SHE Academy with its wonderful people, organizers and peers, was always a great support and resource. During the SHE Academy I had the feeling of not being alone and it was there that I gained the courage to move on.

My gratitude also goes to the Berner Bildungszentrum Pflege, Berne, Switzerland, the institution I work for; I am grateful that I could conduct my research projects there.

Thank you to my family, especially to Magnus my dear friend and husband, who supported me through all these years. To my parents Eveline and Ruedi Schlegel, who believed in me and from whom I received the strength to never give up. It is my deepest wish that I will be able to enjoy my graduation with my parents. I am sorry I can no longer discuss educational matters with my cousin Prof. Edward Schlegel, because he passed away, much too young, in the summer of 2015. But I hope the spark of motivation to educate will spring to his young sons. 


\section{About the author}

Claudia Schlegel, born in 1961 in Basel, Switzerland, took her nursing diploma in 1990 at the nursing school of the Basel University Hospital. After graduation she worked as a nurse in an ambulatory healthcare station in Antalya, Turkey. After returning to Switzerland she completed post-graduate training in anaesthesiology at the Institute of Anaesthesia, at the University Hospital Berne, Switzerland. She also successfully obtained her Master of Medical Education from the University of Berne, Switzerland and started her doctoral studies at Maastricht University, The Netherlands.

For more than 10 years she has been the head of the skills lab at the Berner Bildungszentrum Pflege, Berne, Switzerland and developed the Standardized Patient program there. She was also closely involved with establishing the new skills lab centre, which is considered the benchmark for nursing schools across Europe. 

List of Publications 


\section{ENGLISH ARTICLES}

Schlegel, C. Bonvin, R., Rethans, JJ., van der Vleuten, C. (2015). The use of video in standardized patient training to improve portrayal accuracy: A randomized posttest control group study. Medical Teacher. 37 (8), 730-737. DOI: 10.3109/ 0142159X.2014.970989

Herrmann, G., Woermann, U., \& Schlegel, C. (2014). Interprofessional education in anatomy: Learning together in medical and nursing training. Anatomical sciences education. doi: 10.1002/ase.1506

Schlegel, C. Shaha, M. (2014) Turning old into new. The Clinical Teacher. Vol: 11: 561562.

Schlegel, C., Woermann, U., Rethans, J. J., \& van der Vleuten, C. (2012). Validity evidence and reliability of a simulated patient feedback instrument. [Validation Studies]. BMC Medical Education, 12, 6. doi: 10.1186/1472-6920-12-6

Schlegel, C., Woermann, U., Shaha, M., Rethans, J. J., \& van der Vleuten, C. (2012). Effects of communication training on real practice performance: a role-play module versus a standardized patient module. [Comparative Study Randomized Controlled Trial]. The Journal of Nursing Education, 51(1), 16-22. doi: 10.3928/0148483420111116-02

Schlegel, C., Shaha, M. (2009). The Value of Standardized Patients in Nursing Education. Journal of Nursing Science. Vol.27 No 2: 40-48

\section{GERMAN ARTICLES}

Schlegel, C., Wagner, D. (2015). Lernen nach Drehbuch. Weiterbildung. (5): 18-20.

Schlegel, C. (2014). Interprofessionelles Lernen im Lernbereich Training und Transfer LTT. Pädagogik der Gesundheitsberufe. 09: 37-38

Scheurer Steffen, C., Schlegel, C. (2013). Telefonberatung mit Simulationspatienten. Krankenpflege. 10/ 29

Jenni, E., Schlegel, C. (2012). Validation praktisch anwenden. PADUA. 7/(3): 137-142

Spring, R., Schlegel, C. (2010). Wenn pädagogisches Wissen wirklich zu Wissen wird. Pflegewissenschaft. 11: 554-559.

Schlegel, C. Huber, HR. (2010). Zwischen "Hightec" und "Hightouch". Krankenpflege. 02: 25 
Jenni-Zulliger, E., Schlegel, C. (2009). Die Evaluation im Problem-Based Learning - Eine Herausforderung für Tutorinnen und Tutoren. Pflegewissenschaft. 07: 404-409

Schlegel, C., Shaha, M. (2007). Pilotprojekt: Praxisnahes Unterrichten in der Pflegeausbildung mit Standardisierten Patienten-Ein gewinn für alle! Printernet, 03:167-171.

Schlegel, C., Shaha, M. (2007).Umfassende Überprüfung der Kompetenzen. Krankenpflege. Vol 8: 32

\section{BOOKS}

Schlegel, C. (2015). Feedback von Simulationspatientinnen und -Patienten. 2. Auflage, hep Verlag Bern

Schlegel, C. (2011). Feedback von Simulationspatientinnen und -Patienten. 1. Auflage, hep Verlag Bern

Chapters in the following books:

Schlegel, C. (2008) OSCE (Objective Structured Clinical Examination) in der tertiären Pflegeausbildung-eine Anleitung zur Planung und Durchführung.

In book: Innovatives Lehren und Lernen, Edition: 1. Auflage, Chapter: 11, Publisher: Hans Huber Verlag, Editors: Gerda Nussbaumer, Christine von Reibnitz, pp.181-189

Schlegel, C., (2008) Lernerfolg mit dem Standardisierten Patienten in der Pflegeausbildung.

In book: Innovatives Lehren und Lernen, Edition: 1. Auflage, Chapter: 8, Publisher: Hans Huber Verlag, Editors: Gerda Nussbaumer Christine von Reibnitz, pp.135-145

Schlegel, C., Nussbaumer, G. (2010). Spitex - die Vernetzung und Kooperation in der Schweiz.

In book: Netzwerk Pflege und Gesundheit, Edition: 1st, Chapter: 6 Spitex -Vernetzung und Kooperation in der Schweiz, Publisher: Behr`s Verlag, Hamburg, Editors: Nussbaumer Gerda, von Reibnitz Christine, pp.1-23 



\section{SHE dissertations series}

The SHE Dissertation Series publishes dissertations of PhD candidates from the School of Health Professions Education (SHE) who defended their PhD theses at Maastricht University. The most recent ones are listed below. For more information go to: www.maastrichtuniversity.nl/she.

Van den Eertwegh, V. (11-11-2015) Unravelling postgraduate communication learning; from transfer to transformative learning

Gingerich, A. (03-09-2015) Questioning the rater idiosyncrasy explanation for error variance, by searching for multiple signals within the noise

Goldszmidt, M. (02-09-2015) Communication and reasoning on clinical teaching teams, the genres that shape care and education

Slootweg, I. (19-06-2015) Teamwork of Clinical Teachers in Postgraduate Medical Training

Al-Eraky, M. (21.05.15) Faculty development for medical professionalism in an Arabian context

Wearne, S. (08-04-2015) Is it remotely possible? Remote supervision of general practice registrars

Embo, M. (13-03-2015) Integrating workplace learning, assessment and supervision in health care education

Zwanikken, P. (23-01-2015) Public health and international health educational programmes for low- and middle-income countries: questioning their outcomes and impact

Hill, E. (11-12-2014) A cutting culture: gender and identification in the figured world of surgery

Diemers, A. (03-10-2014) Learning from pre-clinical patient contacts 
Tjiam, I. (17-09-2014) Learning in Urology. Designing simulator based skills Training \& Assessment

Berkenbosch, L. (30-06-2014) Management and leadership education for medical residents

Bergman, E.M. (30-06-2014) Dissecting anatomy education in the medical curriculum

Dijkstra, J. (25-06-2014) Guidelines for designing programmes of assessment

Van Loon, M.H. (08-05-2014) Fostering monitoring and regulation of learning

Frambach, J.M. (26-03-2014) The cultural complexity of problem-based learning across the world

Hommes, J.E. (26-02-2014) How relations, time \& size matter in medical education

Van der Zwet, J. (30-01-2014) Identity, Interaction and Power. Explaining the affordances of doctor-student interaction during clerkships

Watling, C.J. (22-01-2014) Cognition, Culture, and Credibility. Deconstructing Feedback in Medical Education 
